Regi- Appt. Popont $\widehat{L m}$

PRITT

Return to:

Publications Hanagement Unit

1990 WRD

\title{
NATIONAL WATER QUALITY LABORATORY SERVICES CATALOG
}

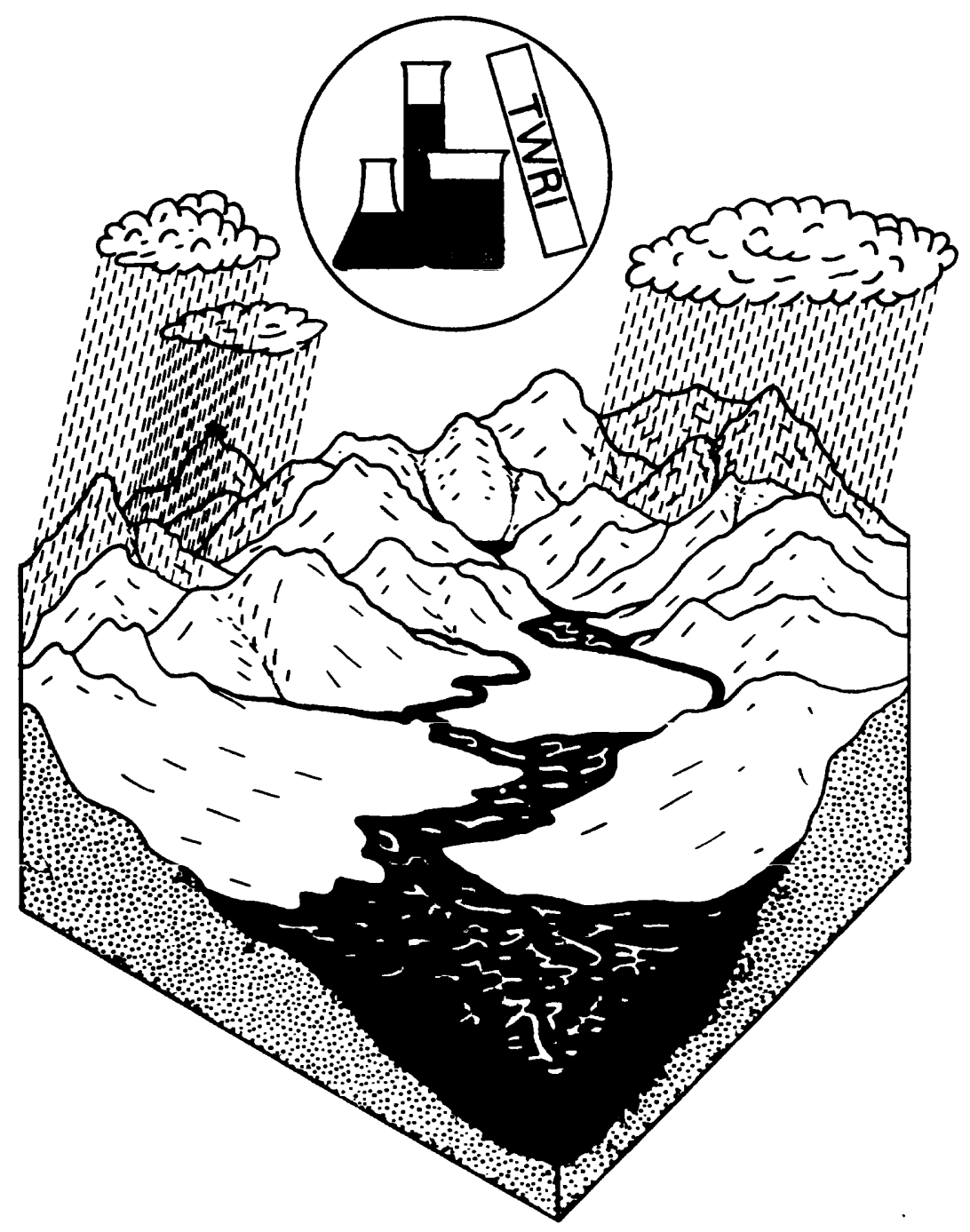

U.S. GEOLOGICAL SURVEY

Open-File Report 89-386

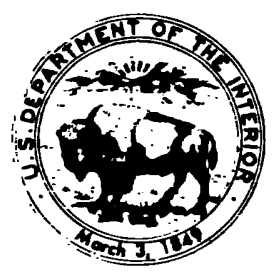





\section{United States Department of the Interior GEOLOGICAL SURVEY \\ BOX 25046 M.S. $40 Z$ \\ DENVER FEDERAL CENTER \\ DENVER, COLORADO 80225-0046}

IN RrPI.I RrtrR IO

November 15, 1989

BRANCH OF ANAL.YTICAL SERVICES TECHNICAL MEMORANDUM NO. 90.01

Subject: PROGRAMS AND PLANS--1990 National Water Quality Laboratory Services Catalog

Attached is a copy of the 1990 National Water Quality Laboratory Services Catalog. Please use it with your existing binder and dividers. If additional copies are needed, you may request them by EDOC to DENSUPPLY. Reasonable numbers are available at no charge.

Several changes will be evident in this catalog. The Method Codes have been added to the WATSTORE Codes, so that you can determine the methodology used for each analysis. The biological parameters have been combined with the organic parameters on Tables 4 and 5, eliminating Tables 4.3 and 5.3. Further modifications to clarify and simplify are anticipated for next year. We would be happy to receive your suggestions for improvement.

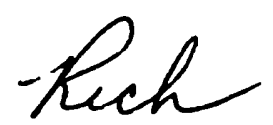

R. 0. Hawkinson

Attachment

Chief, Branch of Analytical Services 



\section{0}

NATIONAL WATER QUALITY LABORATORY

SERVICES CATALOG

Jeffrey Pritt and Berwyn E. Jones, editors

Open-File Report $89-386$

UNITED STATES

DEPARTMENT OF THE INTERIOR

GEOLOGICAL SURVEY

Arvada, Colorado

October 1989 


\section{UNITED STATES DEPARTMENT OF THE INTERIOR}

MANUEL LUJAN, Jr., Secretary

GEOLOGICAL SURVEY

Dallas L. Peck, Director

Catalogs may be obtained from the following offices:

National Water Quality Laboratory U.S. Geological Survey 5293 Ward Road Arvada, Colorado 80002
Office of Water Quality U.S. Geological Survey 412 National Center Reston, Virginia 22092 


\section{PREFACE}

This catalog provides information about analytical services available from the National Water Quality Laboratory (NWQL) to support programs of the Water Resources Division of the U.S. Geological Survey. To assist personnel in the selection of analytical services, the catalog lists cost, sample volume, applicable concentration range, detection level, precision of analysis, and preservation techniques for samples to be submitted for analysis. Prices for services reflect operational costs, the complexity of each analytical procedure, and the costs to ensure analytical quality control.

The catalog consists of five parts. Part 1 is a glossary of terminology; Part 2 lists the bottles, containers, solutions, and other materials that are available through the NWQL; Part 3 describes the field processing of samples to be submitted for analysis; Part 4 describes analytical services that are available; and Part 5 contains indices of analytical methodology and Chemical Abstract Services (CAS) numbers.

Nomenclature used in the catalog is consistent with WATSTORE and STORET. The user is provided with laboratory codes and schedules that consist of groupings of parameters which are measured together in the NWQL. In cases where more than one analytical range is offered for a single element or compound, different laboratory codes are given.

Book 5 of the series "Techniques of Water Resources Investigations of the U.S. Geological Survey" should be consulted for more information about the analytical procedures included in the tabulations.

This catalog supersedes U.S. Geological Survey Open-File Report 86-232 "1986-87-88 National Water Quality Laboratory Services Catalog", October 1985. 


\section{ACKNOWLEDGEMENTS}

The editors appreciate our colleagues at the National Water Quality Laboratory for assisting in the preparation of this catalog. We especially thank Ann Zepp for her patience and tireless efforts preparing the manuscript. 


\section{CONTENTS--continued}

Table 4.2--Inorganic analyses.............. 4-9

4.3--Organic analyses $\ldots \ldots \ldots \ldots \ldots \ldots \ldots . \quad 4-21$

PART 5: Indices of Analytical Methodology and Chemical Abstract Services (CAS) Numbers

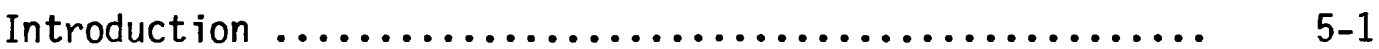

Methods used to derive precision values $\ldots \ldots \ldots \ldots \ldots . .6$. $5-2$

Sources and references for precision data $\ldots . \ldots \ldots \ldots . .6 .5$

Table 5.2--Index of analytical methodology for

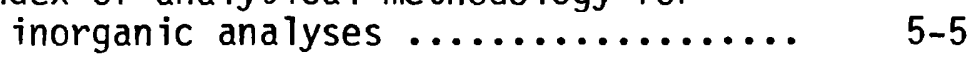

5.3.1--Index of analytical methodology for organic analyses $\ldots \ldots \ldots \ldots \ldots \ldots . .5-23$ 


\section{CONTENTS}

Page

PREFACE

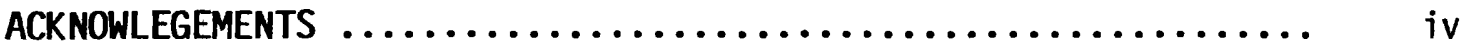

PART 1: Glossary $\ldots \ldots \ldots \ldots \ldots \ldots \ldots \ldots \ldots \ldots \ldots \ldots \ldots \ldots \ldots \ldots$ 1-1

Table 1.1--Explanation and definition of phase and treatment

PART 2: Containers, solutions, and supplies

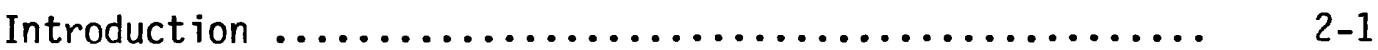

Table 2.2--Containers, solutions, and supplies .... 2-3

PART 3: Sample Processing

Introduction

Table 3.2--Sample designations, containers, and treatments

PART 4: Analytical Services

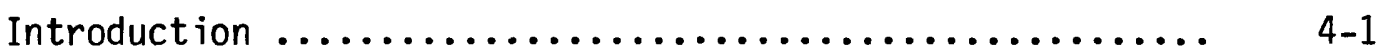

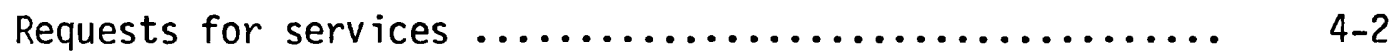

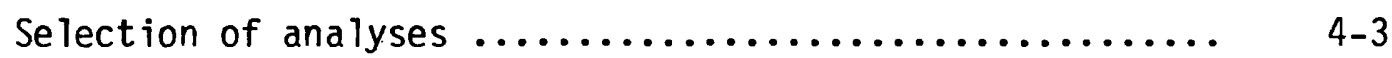

Laboratory schedules ........................ 4-4

Priority pollutants ........................ 4-5

EPA list of organic priority pollutants $\ldots \ldots \ldots \ldots \ldots \ldots$ 4-5

Computerized schedule list $\ldots \ldots \ldots \ldots \ldots \ldots \ldots \ldots \ldots \ldots . . \ldots$ 4-7 
Part 1: Glossary 

Acid-extraction--A procedure in which organic compounds are extracted with methylene chloride under acidic conditions ( $\mathrm{pH} \mathrm{2).}$

Accuracy--A measure of the degree of conformity of the values generated by a specific method or procedure with the true value. The concept of accuracy includes both bias (systematic error) and precision (random error).

Bias--a persistent positive or negative deviation of the values generated by a specific method or procedure from the true value, expressed as the difference between the true value and the mean value obtained by repetitive testing of a homogeneous sample.

Base/neutral-extraction--A procedure in which organic compounds are extracted with methylene chloride under basic conditions ( $\mathrm{pH} 11)$.

Brine--Water that contains dissolved matter at an approximate concentration of $30,000 \mathrm{mg} / \mathrm{L}$ or more.

CAS No.--The Chemical Abstract Services Registry number. This number is one of a series to uniquely identify every chemical substance of known composition and structure. First begun in American Chemical Society publications, the "CAS Registry No." is becoming more prevalent in technical articles, books, and government reports.

Chelation-extraction--A technique employed to complex metal constituents in an aqueous matrix which concentrates the complex in a smaller volume of solvent. Chelation is the reaction between an organic compound and a metal ion that forms a metal-ligand (ML) complex.

Chemical waste--Unuseable byproducts from many chemical and metal-processing operations which often contain toxic or hazardous materials that may become environmental contaminants if disposed of improperly.

Cost--Water quality laboratory analytical cost, without Washington office Technical Service Charge (WOTSC) to WRD users. A cost is associated with each parameter and/or schedule.

Custom analyses--Analyses involving constituents, sample matrices (for example, some biological materials), or concentration levels for which the laboratories have not previously established a procedure, dedicated instrumentation, or thoroughly tested prospective methods. Custom analyses would normally involve extensive methods adaptation, methods development in coordination with current research projects, or purchase of additional equipment to benefit from advances in technology. They will, by their pioneering nature, require a more intensive expenditure of manpower than other classes of service. 
Procedures for acquiring "custom" analytical services will be more formal than those required for other types of analytical services. Requests for such analyses require prior written approval of the Organic or Inorganic Program Chief and the Chief, Branch of Analytical Services. All "custom" analyses will be arranged through written communication with the Branch Chief and will require written acceptance of the necessary conditions by both the requestor and the laboratory before further programming is done or sample collection is started. Requestors of "custom" analyses must describe the need for the service, intended use of the data, and specific needs for accuracy, precision, or sensitivity. Analytical results will normally be reported by formal memorandum from the analyst, documenting the method, the result, and all available QA data which characterize the precision and bias of the method, plus any available information on interferences.

Detection level (method detection limit)--The minimum concentration of a substance that can be identified, measured, and reported with $99 \%$ con idence that the analyte concentration is greater than zero.

The detection level for radioactivity is the quantity of radio-activity equal to twice the standard deviation in a blank (zero concentration).

Dissolved--Constituents of a whole water sample which pass through a 0.45-um membrane filter. This is a convenient operational definition used by Federal Agencies that are collecting water data. Determinations of "dissolved" constituents are made on measured portions of the filtrate. It is recognized that some types of water samples will contain colloidal material which passes through the 0.45 -um filter.

Gravimetry--An analytical procedure in which the mass of a constituent is accurately measured on a calibrated analytical balance.

Hazardous material--Any material or substance, which, if improperly handled, can be damaging to the health and well-being of man. These materials include poisons, toxic agents such as drugs, chemicals, and natural or synthetic products that are harmful, ranging from those that cause skin irritations to those causing death.

Hydride generation--A chemical technique employed to form a gaseous hydride compound of an element of interest prior to determination of the constituent. By forming a gaseous compound, the constituent can be removed from an aqueous matrix which otherwise might interfere with the determination.

Internal Standard--A compound similar in physical and chemical properties to analytes in the sample which is added to the final extract just prior to instrumental analys is. Internal Standard (IS) responses are incorporated into quantitative analysis calculations serving to normalize all data to a known amount of a common reference. IS materials must be chosen careful?y so that they exhibit proper chromatographic behavior and yet do not 
occur either naturally or as a result of pollution. When using mass sensitive detectors, internal standards may be chosen from stable heavy isotope analogs of analytes of interest. Other types of gas and liquid chromatographic detectors require other kinds of compounds. An IS will correct for biases associated with the instrumental determinative step in an analytical procedure.

Ion chromatography--An analytical technique utilizing multiple modes of separation and detection for the routine quantitation of a selected ionic species in the $\mathrm{ug} / \mathrm{L}$ to $\mathrm{mg} / \mathrm{L}$ range.

Lab code--A four digit code in the catalog, always preceded by the letters "LC", and which uniquely represents the analytical method for the constituent measured.

Limited analysis--An analys is performed using an approved method but for which the laboratories can analyze only a limited number of samples per unit of time because of constraints imposed by manpower, time, space, or instruments. (Examples of "limited" analyses are nutrient determinations at $1 \mathrm{ug} / \mathrm{L}$ sensitivity and analys is for methylene chloride extractable organic compounds). To greatly increase the rate of analys is would require additional analysts, a long reaction time, preparation of additional space, and/or purchase of additional equipment. In all cases, a sample load exceeding the current limit of the laboratories would cause an increase in turn-around time for some of the "limited" samples already planned.

An arrangement for "limited" analytical services requires considerable advanced planning. When the laboratory limit is reached, no more requests for analyses will be honored unless previously requested "limited" services for the same type of analyses are decreased, or unless personnel can be diverted from another laboratory section. Annual estimates of the need for "limited" services will be required by the laboratories system to permit optimization of these services. New projects requiring "limited" class analyses should provide advance notice to the laboratories as soon as the need is apparent; that is, during early stages of programming.

Method blank--Extract from pure, organic-free reagent water. A method blank (reagent blank) is generated by subjecting a clean matrix (reagent blank) to the entire analytical procedure.

Method code--A letter code associated with a parameter code which uniquely identifies the analytical method used to determine a constituent. Method codes are now included in WATSTORE, and have been added to this catalog for purposes of identification. 
Method number--An alpha-numeric combination which is unique to each method described in U.S. Geological Survey TWRI, Book 5, Chapters A1-A5. The letter represents the type of parameter $(B=$ Biological, $I=$ Inorganic, 0 = Organic, $P=$ Physical, $R=$ Radiochemical) and the last two digits of the number represent the year of last revision.

Periphyton--Plants attached to surfaces in an aquatic environment.

Phase/treatment--See Table 1.1.

Phytoplankton--Floating plants in an aquatic environment.

Precision--The degree of agreement of repeated measurements by a specific method or procedure, expressed in terms of dispersion of the values generated about the mean value obtained by repetitive testing of a homogeneous sample. Precision values expressed as percent relative standard deviation are listed for low, medium, and high values in the method ranges (tables 5.2, 5.3 and 5.4). Percent relative standard deviation for total-recoverable, suspended-recoverable and measurements of constituents in bottom material will likely be greater than values reported for dissolved measurements.

In general, the detection limit has not been used in computing the lowend precision value because of possible distortion. Low end precision values are usually computed at 5 times the detection limit.

Priority analysis--The priority assigned to analysis of samples which will result in immediate analys is or the samples being added to the next set of samples to be analyzed for the constituent(s) requested. Assignment of this priority must be arranged with the Chief of the Organic or Inorganic Program prior to submitting samples. Requests for "Priority Analysis" must be made in writing and the Program Chief will confirm the request in writing. If a requested schedule cannot be established, the Chief, Branch of Analytical Services should be contacted to achieve reconciliation. If less than normal turnaround time is requested, a minimum surcharge of 50 percent over the catalog price will be added if the priority work cannot be accommodated without disrupting the normal flow of work.

Priority pollutants--A list of toxic chemicals prepared by the U.S. Environmental Protection Agency (EPA) in response to a June 7, 1978, court settlement involving the EPA and several environmentally concerned plaintiffs stemming from the mandate for publication of toxic pollutants in conformance with the Federal Water Pollution Control Act of 1972.

Range--The minimum and maximum values measured by the method, expressed in units with those reported for the parameter. Bottom-material ranges are ordinarily calculated by dividing the minimum concentration allowable in the sample extract (computed from the comparable water method) by the maximum weight of sample likely to be used, and by dividing the maximum concentration allowable by the likely minimum weight. 
Table 1.1.--Explanation and definition of phase and treatment

\begin{tabular}{|c|c|c|c|c|}
\hline 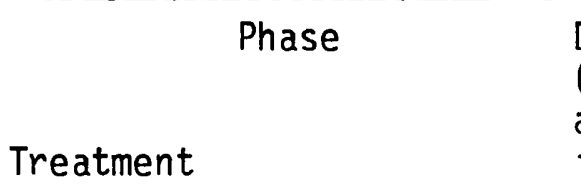 & $\begin{array}{l}\text { Dissolved } \\
\text { (filtration through } \\
\text { a } 0.45 \text { um filter or } \\
\text { its equivalent) }\end{array}$ & Suspended & $\begin{array}{l}\text { Dissolved } \\
\text { and } \\
\text { suspended }\end{array}$ & $\begin{array}{l}\text { Bottom } \\
\text { material }\end{array}$ \\
\hline $\begin{array}{l}\text { Complete }(<95 \%) \text { extraction } \\
\text { from solid phase (actual or } \\
\text { calculated on basis of } \\
\text { extraction efficiency) }\end{array}$ & $r$ & $\begin{array}{l}\text { Total } \\
\text { suspended }\end{array}$ & Total & $\begin{array}{l}\text { Total in } \\
\text { bottom material }\end{array}$ \\
\hline $\begin{array}{l}\text { Extraction } \\
\text { from solid } \\
\text { phase less } \\
\text { than complete (on } \\
\text { nonreproducible) }\end{array}$ & -- & $\begin{array}{l}\text { Suspended } \\
\text { recoverable }\end{array}$ & $\begin{array}{l}\text { Total } \\
\text { recoverable }\end{array}$ & $\begin{array}{l}\text { Recoverable from } \\
\text { bottom material }\end{array}$ \\
\hline $\begin{array}{l}\text { Filtered } \\
(0.45 \text { um) }\end{array}$ & Dissolved & -- & -- & -- \\
\hline
\end{tabular}


Recoverable from bottom material--The amount of a given constituent that is in solution after a bottom material sample has been extracted or digested by a method that results in dissolution of readily soluble substances. Complete dissolution of all bottom material is not achieved by the digestion treatment employed, and there is reason to believe that the determination represents less than the total amount (less than 95 percent) of the constituent sought in the sample. To ensure comparability of analytical data, equivalent digestion procedures must be used by all laboratories performing such analyses.

Regular analysis--An analysis which is performed routinely by the laboratory in which the concentration of the constituent of interest and the analytical interferences are within limits specified in approved methods for that constituent. "Regular" samples will be accepted by the NWQL without advance notification. Special requirements such as rapid completion time, a lower detection level than that specified in the method, or processing of unusual matrices (for example, sewage or industrial effluent), will place the sample in the "special" category which requires advance arrangements with the appropriate Program Chief before any program commitment can be made.

Reporting level--The lowest measured concentration of a constituent that may be reliably reported using a given analytical method. Due to unpredictable matrix effects on detection limits, the reporting limit is set somewhat higher than the detection limit.

Sample designation--Symbols which specify the type of container and pretreatment which the sample must receive. These symbols are required to be marked on the sample container.

Schedule number--A number preceded by the letters "SH" which represents a group of determinations. The laboratory will assume the responsibility for meeting any constraint specified in the schedule (e.g., detection level) and will select appropriate methodology.

Special analysis--An analys is not routinely performed in the NWQL. If an analytical method has been developed, the method is tabulated in the catalog; others will be announced by the NWQL as they are developed. Requests for this type of service should be submitted in writing to the Organic or Inorganic Program Chief. The technical approach and analytical cost must be accepted in writing by both requestor and laboratory. The difficulty of analysis, manpower required, and the number of samples to be analyzed will determine analytical cost.

Samples of grossly polluted or potentially contaminated water that could cause either health or analytical difficulties in the laboratory, special batches, or large numbers of analyses for which reduced costs are negotiated, and samples which require special preparation or faster-thannormal turnaround, all fall into the "special" category. 
Spike--The addition of a known amount of one or more compounds of interest to the sample prior to analysis. Analys is yields accuracy data from a synthetic matrix or recovery data from an authentic matrix. Accuracy reflects the best results which can be expected and recovery reflects the degree of influence of matrix effects upon accuracy.

Surrogate--A compound similar in physical and chemical properties to the analytes of interest which is added to the sample upon receipt in the laboratory (or ideally at the time of field sampling). A surrogate is not used as an internal standard for quantitative measurement purposes. Surrogates may be added to every sample to provide quality control by monitoring for matrix effects and gross sample processing errors. Surrogates should not occur naturally or be present in polluted water samples. The term "surrogate spike" is used synonymously with "surrogate."

Suspended, recoverable--The amount of a given constituent that is in solution after the material which is retained on a $0.45-$ um membrane filter has been digested by a method (usually with an acid or mixture of acids) that results in dissolution of readily soluble substances. More commonly, the difference between determinations of total recoverable and dissolved concentrations of the constituent is reported.

Suspended, total--That material which is retained on a 0.45-um membrane filter. Determinations of "suspended" constituents are made either by analyzing portions of the material collected on the filter, or calculated by the difference between total and dissolved concentrations of the constituents.

Titrimetry--an analytical procedure in which an accurately measured volume of solution of known concentration reacts with an exact equivalent amount of the substance being determined.

Total--The total amount of a given constituent (dissolved plus suspended) in a water-suspended sediment sample, regardless of its physical or chemical form. This term is used only when the analytical procedure assures the measurement of at least 95 percent of the constituent present in both phases of the sample. A knowledge of the expected form of the constituent in the sample, as well as the analytical methodology used, is required to judge when the results should be reported as "total".

Total in bottom material--The total amount of a given constituent in a bottom material sample, regardless of its physical or chemical form. This term is used only when the analytical procedure assures the measurement of at least 95 percent of the constituent present in the sample. A knowledge of the expected form of the constituent in the sample, as well as the analytical methodology used, is required to judge when the results should be reported as "total". 
Total recoverable--The amount of a given constituent that is in solution after a water-suspended sediment sample or bottom-material sample has been extracted or digested by a method that results in dissolution of readily soluble substances. Complete dissolution of all particulate matter is not achieved by the extraction or digestion treatment employed and there is reason to suspect that the determination actually represents something less than the "total" amount (95 percent) of the constituent sought in both phases of the sample.

Volume or weight needed--The volume or weight of sample necessary for analysis. When more than one determination is requested, the volume or weight needed may be different from the requirements for the number of individual determinations because of multiple constituent analysis capability. When supplying the required amount of sample is a problem, the laboratories should be consulted on the actual amount of sample needed for multi-constituent analys is.

WATSTORE code--Five digit parameter code (conforming to STORET code) used to permanently store and retrieve values in and from a computerized data management system. The WATSTORE code may correspond to more than one lab code. 
Part 2: Containers, Solutions, and Supplies 



\section{Introduction}

The containers, solutions, and supplies for use in collecting and processing samples for analys is by the NWQL are available from several different sources. The sources are identified as part of the order number by referring to the footnote on Table 2.2.

Generally, there is no charge for sample containers; however, bottles made from Teflor ${ }^{B}$, bottles used for sterile, buffered water, and the small bottles used for packaging the bacteriological media kits are accountable and return-

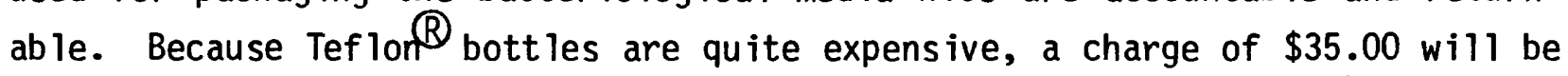
made for each bottle requested, and a like amount will be credited when the bottles are returned to the laboratory. 


\section{Introduction}

The containers, solutions, and supplies for use in collecting and processing samples for analysis by the NWQL are available from either the NWQL (D) or the Ocala laboratory $(\emptyset)$. Samples submitted to NWQL should utilize NWQL supplies and containers, in order to insure the integrity of NWQL analyses.

Because many District customers wish to use NWQL-prepared bottles for samples which are not analyzed in this laboratory, the cost of containers and preservatives is no longer included in the cost of NWQL analyses, but is separately billed. The prices quoted in the following table are computed to recover the cost of purchasing, cleaning (as needed) and quality assuring the item. Because Teflon bottles are quite expensive, a cleaning charge of $\$ 15.00$ will be made for each bottle requested. These Teflon $R$ bottles remain the property of NWQL, and are to be used or returned promptly.

To order containers and supplies from NWQL, EDOC a message to DENSUPPLY:

(1) List each item ordered exactly as described in the following table.

(2) State the number of units ordered (e.g., 5 packs of 25).

(3) Give account number to be charged.

(4) Give name and address to which supplies should be shipped. 
$\begin{array}{ll}2-2 & 10 / 89\end{array}$ 


\begin{tabular}{|c|c|c|c|c|}
\hline Container or supplied item & $\begin{array}{l}\text { Obtain } \\
\text { from }\end{array}$ & $\begin{array}{l}\text { Sample } \\
\text { designation }\end{array}$ & $\begin{array}{l}\text { Unit } \\
\text { supplied }\end{array}$ & $\begin{array}{l}\text { Price } \\
(\$)\end{array}$ \\
\hline $\begin{array}{l}\text { Ampule, } \mathrm{H}_{3} \mathrm{PO}_{4} / \mathrm{CuSO}_{4} \\
\text { Ampule, } \mathrm{HgCl}_{2}-\mathrm{NaCl}_{1} 1 \mathrm{~mL}(10 \mathrm{mg} \mathrm{Hg}) \\
\text { Ampule, nitric acid, } 1 \mathrm{~mL} \\
\text { Ampule, nitric acid, } 2 \mathrm{~mL} \\
\text { Ampule, nitric acid/potassium dichromate, } 10 \mathrm{~mL}\end{array}$ & $\begin{array}{l}\emptyset \\
D \\
D \\
D \\
D\end{array}$ & $\begin{array}{l}\text { LCO052 } \\
F C, R C \\
F A, R A, R A E, R A H \\
F A, R A \text {, } \\
\text { FAM, RAM }\end{array}$ & $\begin{array}{l}25 / \text { pack } \\
25 / \text { pack } \\
25 / \text { pack } \\
25 / \text { pack } \\
25 / \text { pack }\end{array}$ & $\begin{array}{l}35.00 \\
36.80 \\
43.65 \\
43.65 \\
39.40\end{array}$ \\
\hline $\begin{array}{l}\text { Ampule, nitric acid, ultrapure } 1 \mathrm{~mL} \\
\text { Ampule, copper sulfate, } 5 \%, 5 \mathrm{~mL} \\
\text { Ampule, sodium hydroxide, } 5 \mathrm{NL}, 5 \mathrm{~mL} \\
\text { Ampule, sulfuric acid, } 50 \%, 4 \mathrm{~mL} \\
\text { Ampule, sulfuric acid, } 1 \mathrm{~mL}\end{array}$ & $\begin{array}{l}D \\
D \\
D \\
D \\
D\end{array}$ & $\begin{array}{l}\text { FAB, RAB } \\
\text { LCO052 } \\
\text { LC0880, LC0023 } \\
-- \\
\text { LC0076 }\end{array}$ & $\begin{array}{l}25 / \text { pack } \\
25 / \text { pack } \\
25 / \text { pack } \\
25 / \text { pack } \\
25 / \text { pack }\end{array}$ & $\begin{array}{r}147.90 \\
30.75 \\
30.75 \\
32.40 \\
28.60\end{array}$ \\
\hline $\begin{array}{l}\text { AmpuTe, sulfuric acid, } 2 \mathrm{~mL} \\
\text { Bag, Mesh, 14" x 16" } \\
\text { Bag, Mesh, 16" x } 24 " \\
\text { Bag, Geo. Sample, Hubco, 6" × } 10 " \text { w/tag } \\
\text { Bag, Bubble, 1 L, 6" } 69 "\end{array}$ & $\begin{array}{l}D \\
D \\
D \\
D \\
D\end{array}$ & $\begin{array}{l}\text { LCO127 } \\
-- \\
-- \\
-- \\
--\end{array}$ & $\begin{array}{l}25 / \text { pack } \\
1 \text { each } \\
1 \text { each } \\
1 \text { each } \\
1 \text { each }\end{array}$ & $\begin{array}{r}28.60 \\
0.55 \\
0.90 \\
0.25 \\
0.15\end{array}$ \\
\hline $\begin{array}{l}\text { Bottle, glass, } 125 \mathrm{~mL} \\
\text { Bottle, glass, baked, } 125 \mathrm{~mL}\end{array}$ & $\begin{array}{l}D \\
D\end{array}$ & \multirow{3}{*}{$\begin{array}{l}\text { LCO489, LC300 } \\
\text { LC0019, LC0076, LC0113, } \\
\text { LC0114, LC0306 } \\
\text { FAM, RAM } \\
\text { GCC, LC0052, LCO995, LC0881 } \\
\text { LC1043, LC0460 }\end{array}$} & $\begin{array}{l}24 / \text { case } \\
24 / \text { case }\end{array}$ & $\begin{array}{l}20.50 \\
25.80\end{array}$ \\
\hline $\begin{array}{l}\text { Bottle, glass, acid rinsed, } 250 \mathrm{~mL} \\
\text { Bottle, glass, pest., baked, } 1 \mathrm{~L}\end{array}$ & $\begin{array}{l}D \\
D\end{array}$ & & $\begin{array}{l}24 / \text { case } \\
12 / \text { case }\end{array}$ & $\begin{array}{l}36.40 \\
26.80\end{array}$ \\
\hline Bottle, glass, Mayo, baked, 1 qt. & $D$ & & $12 /$ case & 30.10 \\
\hline $\begin{array}{l}\text { Bottle, glass, wide mouth, baked, } 500 \mathrm{~mL} \\
\text { Bottle, glass, wide mouth, baked, } 1 \mathrm{~L} \\
\text { Bottle, polyethylene, } 125 \mathrm{~mL} \text { (caps must be ordered separately) }\end{array}$ & $\begin{array}{l}D \\
D \\
D\end{array}$ & \multirow{3}{*}{$\begin{array}{l}\text { BGC } \\
\text { LCO440, LCO298, LC1199 } \\
\text { RU, FU, LC0050, } \\
\text { LCO068, LC0069 } \\
\text { FU, RU, RCB, LCO023, } \\
\text { LCO089, LC0880, LCO452 } \\
\text { FU, RU, LC0169 }\end{array}$} & $\begin{array}{l}12 / \text { case } \\
12 / \text { case } \\
550 / \text { case }\end{array}$ & $\begin{array}{l}35.50 \\
38.20 \\
83.00\end{array}$ \\
\hline Bottle, polyethylene, $250 \mathrm{~mL}$ (caps must be ordered separately) & $D$ & & $500 /$ case & 106.25 \\
\hline Bottle, polyethylene, $500 \mathrm{~mL}$ (caps must be ordered separately) & $D$ & & $256 /$ case & 73.15 \\
\hline $\begin{array}{l}\text { Bottle, polyethylene, wide mouth, sediment, } 500 \mathrm{~mL} \\
\text { Bottle, po lyethylene, I L (caps must be ordered separately) } \\
\text { Bottle, polyethylene, with handle, acid rinsed, } 2 \mathrm{~L} \\
\text { Bottle, polyethylene, acid rinsed, } 250 \mathrm{~mL} \\
\text { Bottle, polyethylene, acid rinsed, } 500 \mathrm{~mL}\end{array}$ & $\begin{array}{l}D \\
D \\
D \\
D \\
D\end{array}$ & $\begin{array}{l}\text { CC, CU } \\
\text { FU, RU } \\
\text { RUR, FAR } \\
\text { FA, RA, RAE, RAH } \\
\text { FA, RA }\end{array}$ & $\begin{array}{l}1 \text { each } \\
108 / \text { case } \\
4 / \text { case } \\
500 / \text { case } \\
256 / \text { case }\end{array}$ & $\begin{array}{r}2.10 \\
53.80 \\
12.10 \\
285.60 \\
170.60\end{array}$ \\
\hline $\begin{array}{l}\text { Bottle, polyethylene, acid rinsed, } 1 \mathrm{~L} \\
\text { Bottle, polyethylene, brown, } 250 \mathrm{~mL}\end{array}$ & $\begin{array}{l}D \\
D\end{array}$ & $\begin{array}{l}\text { FAR, RUR } \\
\text { FC, FCL, RC, RCL }\end{array}$ & $\begin{array}{l}108 / \text { case } \\
500 / \text { case }\end{array}$ & $\begin{array}{l}109.15 \\
115.25\end{array}$ \\
\hline
\end{tabular}

(Obtain from: D, Denver laboratory. $\emptyset$, QW Service Unit, Ocala, Florida. Cost: (1) cleaning and QA charge. Bottle to be returned to labora- 


\begin{tabular}{|c|c|c|c|c|}
\hline Container or supplied item & $\begin{array}{l}\text { Obtain } \\
\text { from }\end{array}$ & $\begin{array}{c}\text { Sample } \\
\text { designation }\end{array}$ & $\begin{array}{c}\text { Unit } \\
\text { supplied }\end{array}$ & $\begin{array}{c}\text { Price } \\
(\$)\end{array}$ \\
\hline $\begin{array}{l}\text { Bottle, polyethylene, brown, } 1 \mathrm{~L} \text { (caps must be ordered separately) } \\
\text { Bottle, teflon, acid rinsed, } 250 \mathrm{~mL} \\
\text { Bubbler, glass } \\
\text { Caps, plastic, size } 28-400 \text {, black } \\
\text { Filters, silver and/or biological }\end{array}$ & $\begin{array}{l}D \\
D \\
D \\
D \\
\emptyset\end{array}$ & $\begin{array}{l}-- \\
\text { FAB, RAB } \\
\text { LCO490 } \\
-- \\
--\end{array}$ & $\begin{array}{l}108 / \text { case } \\
1 \text { each } \\
1 \text { each } \\
800 / \text { cs }\end{array}$ & $\begin{array}{r}59.15 \\
15.00(1) \\
125.00 \\
17.15\end{array}$ \\
\hline $\begin{array}{l}\text { Kit, media, agar, fecal coliform } \\
\text { Kit, media, agar, fecal strep } \\
\text { Kit, media, agar, total coliform } \\
\text { Kit, periphyton, chlorophyll and biomass } \\
\text { Kit, phytoplankton, chlorophyll }\end{array}$ & $\begin{array}{l}\emptyset \\
\emptyset \\
\emptyset \\
\emptyset \\
\emptyset\end{array}$ & $\begin{array}{l}-- \\
-- \\
\overline{C H E} \\
\mathrm{CHY}\end{array}$ & $\begin{array}{l}15 / k i t \\
15 / k i t \\
15 / k i t \\
1 \text { kit } \\
1 \text { kit }\end{array}$ & $\begin{array}{l}(2) \\
(2) \\
(2) \\
(2) \\
(2)\end{array}$ \\
\hline 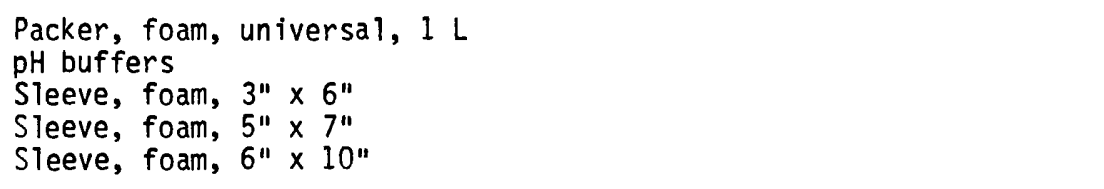 & $\begin{array}{l}D \\
\emptyset \\
D \\
D \\
D\end{array}$ & $\begin{array}{l}-- \\
\text { LCO051 } \\
-- \\
--\end{array}$ & $\begin{array}{l}1 \text { each } \\
1 \text { each } \\
1 \text { each } \\
1 \text { each } \\
1 \text { each }\end{array}$ & $\begin{array}{l}2.45 \\
(2) \\
0.10 \\
0.15 \\
0.17\end{array}$ \\
\hline 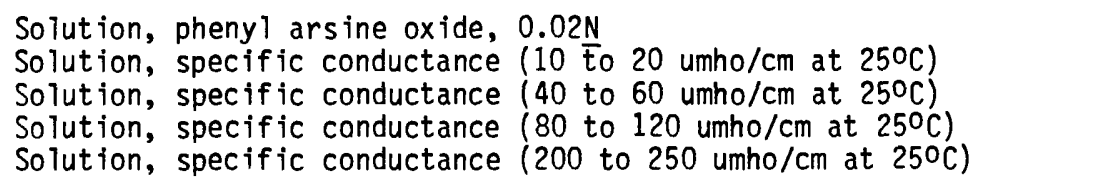 & $\begin{array}{l}\emptyset \\
H \\
H \\
H \\
H\end{array}$ & $\begin{array}{l}\text { LCO025 } \\
\text { LCO021 } \\
\text { LCO021 } \\
\text { LCO021 } \\
\text { LCO021 }\end{array}$ & $\begin{array}{l}1 \mathrm{~L} \\
4 \mathrm{~L} \\
4 \mathrm{~L} \\
4 \mathrm{~L} \\
4 \mathrm{~L}\end{array}$ & $\begin{array}{l}(2) \\
(3) \\
(3) \\
(3) \\
(3)\end{array}$ \\
\hline $\begin{array}{l}\text { Solution, specific conductance }(4,000 \text { to } 5,000 \text { umho/cm at } 250 \mathrm{C}) \\
\text { Solution, specific conductance }(7,500 \text { to } 8,500 \text { umho/cm at } 250 \mathrm{C}) \\
\text { Solution, spec if ic conductance }(10,500 \text { to } 11,500 \text { umho/cm at } 250 \mathrm{C} \text { ) } \\
\text { Solution, sulfuric acid,. } 0164 \mathrm{~N} \text { (approx.) } \\
\text { Tablet, } \mathrm{HgCl}_{2}-\mathrm{NaCl}(10 \mathrm{mg} \mathrm{Hg})\end{array}$ & $\begin{array}{l}H \\
H \\
H \\
\emptyset \\
D\end{array}$ & $\begin{array}{l}\text { LCO021 } \\
\text { LCOO21 } \\
\text { LCO021 } \\
\text { LCO002 } \\
\text { LCO300, LCO440 }\end{array}$ & $\begin{aligned} 4 \mathrm{~L} \\
4 \mathrm{~L} \\
4 \mathrm{~L} \\
1 \mathrm{~L} \\
100 / \text { card }\end{aligned}$ & $\begin{array}{c}(3) \\
(3) \\
(3) \\
(2) \\
131.00\end{array}$ \\
\hline $\begin{array}{l}\text { Vial, glass, amber septum, } 40 \mathrm{~mL} \\
\text { Water, di lution, buffered, sterile, bacteriological samples, } 99 \mathrm{~mL} \\
\text { Water, rinse, buffered, sterile, bacteriological samples, } 250 \mathrm{~mL} \\
\text { Zinc acetate, } 25 \mathrm{~g}\end{array}$ & $\begin{array}{l}D \\
\emptyset \\
\emptyset \\
\emptyset\end{array}$ & $\begin{array}{l}\text { GCV } \\
-- \\
\overline{L C}\end{array}$ & $\begin{array}{l}72 / \text { box } \\
12 / \text { box } \\
8 / \text { pack } \\
1 \text { jar }\end{array}$ & $\begin{array}{l}100.45 \\
(2) \\
(2) \\
(2)\end{array}$ \\
\hline
\end{tabular}

(Obtain from: D, Denver laboratory; H, Hydrologic Instrumentation Facility; $\emptyset$, QW Service Unit, Ocala, Florida. Cost: (1) cleaning and QA charge. Bottle to be returned to laboratory; (2) information available from Ocala; (3) information available from HIF on Computerized
Support System.) 
Part 3: Sample Processing 



\section{Introduction}

The quality of data produced by the NWQL is enhanced by proper sample collection, preservation, and expeditious shipment of samples to the laboratory. To insure the integrity of analyses, samples should be submitted to NWQL only using containers and preservatives supplied and quality-assured by NWQL.

Table 3.2 cross references the types of containers with sample treatment and preservation requirements. Most of the types of sample containers needed are listed in Table 2.2, "Containers, solutions, and supplies". The specific type of container for a particular determination is listed under the column heading "sample designation" in Tables 4.2, 4.3, and 4.4 .

Special attention is directed to the bottles used for submitting "total oil and grease" and "total phenol" samples. The bottles should be used only as labeled. Bottles for oil and grease and the bottles for phenol are baked at $350^{\circ} \mathrm{C}$ prior to shipment to the user. Samples for the total phenol determination (LCOO52) should be collected in glass bottles only and preserved by the addition of phosphoric acid and copper sulfate solution. To one liter of sample, add $2 \mathrm{~mL}$ of $8.5 \%$ phosphoric acid and mix. Determine $\mathrm{pH}$, and if above 4, add phosphoric acid until it is below 4. Add $10 \mathrm{~mL}$ of copper sulfate solution $(100 \mathrm{~g} / \mathrm{L})$ and mix. The sample should be protected from sunlight, chilled to $4^{\circ} \mathrm{C}$, and shipped without delay. Temperature control should be ensured during transit.

Bottom-material samples submitted to the laboratories should be presieved through a 2.0-mm sieve using a minimum of native water. A charge of $\$ 49.00$ will be made for samples requiring sieving by laboratory personnel. Samples will be sieved as time permits, and turnaround time will be longer than normal. 
3-2 


\begin{tabular}{|c|c|c|}
\hline \multicolumn{2}{|c|}{ Inorganic determinations: } & water and water-sediment sample \\
\hline $\mathrm{FA}$ & 250 or $500 \mathrm{~mL}$ & Poly bottle, acid rinsed \\
\hline$F A B$ & $250 \mathrm{~mL}$ & Teflon bottle, acid rinsed \\
\hline FAM & $250 \mathrm{~mL}$ & Glass bottle, acid rinsed \\
\hline FAR & 1 or $2 \mathrm{~L}$ & Poly bottle, acid rinsed \\
\hline FC & $250 \mathrm{~mL}$ & Brown poly bottle, field rinsed \\
\hline FU & 250 or $500 \mathrm{~mL}$ & Poly bottle, field rinsed \\
\hline RA & 250 or $500 \mathrm{~mL}$ & Poly bottle, acid rinsed \\
\hline RAB & $250 \mathrm{~mL}$ & Teflon bottle, acid rinsed \\
\hline RAE & $250 \mathrm{~mL}$ & Poly bottle, acid rinsed \\
\hline RAH & $250 \mathrm{~mL}$ & Poly bottle, acid rinsed \\
\hline RAM & $250 \mathrm{ml}$ & Glass bottle, acid rinsed \\
\hline $\mathrm{RC}$ & $250 \mathrm{~mL}$ & Brown poly bottle, field rinsed \\
\hline $\mathrm{RCB}$ & $250 \mathrm{~mL}$ & Poly bottle, field rinsed \\
\hline $\mathrm{RU}$ & 250 or $500 \mathrm{~mL}$ & Poly bottle, field rinsed \\
\hline RUR & 1 or $2 L$ & Poly bottle, acid rinsed \\
\hline LCO023 & $250 \mathrm{~mL}$ & Poly bottle, field rinsed \\
\hline LCO050 & $125 \mathrm{~mL}$ & Poly bottle \\
\hline LCO076 & $125 \mathrm{~mL}$ & Glass bottle, baked at $350^{\circ} \mathrm{C}$ \\
\hline LC0089 & $250 \mathrm{~mL}$ & Poly bottle, field rinsed \\
\hline LCO169 & $500 \mathrm{~mL}$ & Poly bottle, field rinsed \\
\hline LCO298 & $1 L$ & Glass bottle, field rinsed \\
\hline LCO300 & 125 & Glass bottle, field rinsed \\
\hline LCO440 & $500 \mathrm{~mL}$ & Glass bottle, field rinsed \\
\hline
\end{tabular}

Filter and acidify with $\mathrm{HNO}_{3}$ to $\mathrm{pH}<2$.

Filter and acidify with ultra pure $\mathrm{HNO}_{3}$ to $\mathrm{pH}<2$.

Filter and acidify with $1 \mathrm{HNO}_{3} / \mathrm{K}_{2} \mathrm{Cr}_{2} \mathrm{O}_{7}$ ampule

Filter and acidify with $\mathrm{HNO}_{3}$ to $\mathrm{pH}<2$.

Filter, add ampule $\mathrm{HgCl}_{2}$ sol'n,

chill and maintain at $4{ }^{\circ} \mathrm{C}$.

Filter.

Acidify with $\mathrm{HNO}_{3}$ to $\mathrm{pH}<2$.

Acidify with ultra pure $\mathrm{HNO}_{3}$ to $\mathrm{pH}<2$.

Acidify with $\mathrm{HNO}_{3}$ to $\mathrm{pH}<2$.

Acidify with $\mathrm{HNO}_{3}$ to $\mathrm{pH}<2$.

Add $1 \mathrm{HNO}_{3} / \mathrm{K}_{2} \mathrm{Cr}_{2} \mathrm{O}_{7}$ ampule

Add 1 ampule $\mathrm{HgCl}_{2}$ sol' $\mathrm{n}$, chill and maintain at $4^{\circ} \mathrm{C}$.

Chill and maintain at $4^{\circ} \mathrm{C}$.

Untreated.

Untreated.

Add $\mathrm{NaOH}$ to $\mathrm{pH}>12$, chill and maintain at $4^{\circ} \mathrm{C}$.

Untreated

- Add $\mathrm{H}_{2} \mathrm{SO}_{4}$ to $\mathrm{pH}<2$; chill and maintain at $4^{\circ} \mathrm{C}$.

Add $0.5 \mathrm{~g}$ zinc acetate.

Untreated.

Contact Denver laboratory.

Filter, add $1 \mathrm{HgCl}_{2}$ tablet, seal with wax or plastic tape.

Filter, add $1 \mathrm{HgCl}_{2}$ tablet, $50 \mathrm{~mL}$ ammoniacal $\mathrm{SrCl}_{2}$, use Teflon coated or polyseal cap.

(Remarks: A, Container size dependent on lab schedule; B, filter thru 0.45 micron filter). 
Sample

Designation

Container

Size and type

Treatment and preservation

Remarks

\section{Inorganic determinations: water and water-sediment samples--Continued}

LC0452 $250 \mathrm{~mL} \quad$ Poly bottle, field rinsed

LC0460 $1 \mathrm{~L} \quad$ Glass bottle, field rinsed

LC0489 $\quad 125 \mathrm{~mL} \quad$ Glass bottle, field rinsed

LC0490 $\quad 50 \mathrm{~mL}$ Glass bubbler

LC0880 $\quad 250 \mathrm{~mL} \quad$ Poly bottle, field rinsed

LC0995 1 L Glass bottle, field rinsed

LC1043 $1 \mathrm{~L}$ Glass bottle. field rinsed

LC1199 2 L Glass bottle, field rinsed

Untreated.

Untreated

Filter, add $1 \mathrm{HgCl}_{2}$ tablet, seal with wax or plastic tape.

Contact Denver laboratory.

Filter, add $\mathrm{NaOH}$ to $\mathrm{pH}>12$, chill and maintain

$$
\text { at } 4^{\circ} \mathrm{C} \text {. }
$$

Contact Denver laboratory.

Untreated

Contact Denver laboratory

Inorganic determinations: bottom material samples

CC $\quad 1 \mathrm{pt}$ Poly bottle, wide mouth

CU 1 pt Poly bottle, wide mouth

Organic determinations: water and water-sediment samples

$\begin{array}{lcl}\text { GCC } & 1 \mathrm{~L} & \text { Glass bottle } \\ \text { GCV } & 40 \mathrm{~mL} & \text { Glass septum vial } \\ & & \\ \text { RCB } & 250 \mathrm{~mL} & \text { Poly bottle } \\ \text { LC0019 } & 125 \mathrm{~mL} & \text { Glass bottle }\end{array}$

Bottle baked at $350^{\circ} \mathrm{C}$ by laboratory. Chill sample and maintain at $4^{\circ} \mathrm{C}$.

Exclude air bubbles by completely filling vial. If residual chlorine present, add sodium thiosulfate crystals. Protect sample from sunlight, chill and maintain at $4^{\circ} \mathrm{C}$.

Chill and maintain at $4^{\circ} \mathrm{C}$.

Bottle baked at $350^{\circ} \mathrm{C}$ by laboratory. Chill sample and maintain at $4^{\circ} \mathrm{C}$.

(Remarks: B, filter thru 0.45 micron filter.) 
Sample

designation

Container Size and type

Treatment and preservation

\section{Organic determinations: water and water-sediment samples--Cont inued}

LC0052 $1 \mathrm{~L}$ Glass bottle

LC0113 $\quad 125 \mathrm{~mL} \quad$ Glass bottle

$\begin{array}{lrl}\text { LC0114 } & 125 \mathrm{~mL} & \text { Glass bottle } \\ \text { LC0127 } & 1 \mathrm{~L} & 0>\text { G bottle }\end{array}$

LCO305 Petri dish

LC0306 $\quad 125 \mathrm{~mL} \quad$ Glass bottle

\section{Organic determinations: botton material samples}
$B G C$
$1 \mathrm{~L}$
Wide mouth glass bottle

\section{Biological determinations}

CHE

Glass jar, wide mouth

$\mathrm{CHY}$
Glass vial
Bottle baked at $350^{\circ} \mathrm{C}$ by laboratory. Leave small air space in bottle. Add $2 \mathrm{~mL} 8.5 \% \mathrm{H}_{3} \mathrm{PO}_{4}$ to $1 \mathrm{~L}$ (to $\mathrm{pH} 4$ ) and $10 \mathrm{~mL} \mathrm{CuSO} 4(100 \mathrm{~g} / \mathrm{L})$, or add one ampule $\mathrm{H}_{3} \mathrm{PO}_{4} / \mathrm{CuSO}_{4}$ Chill sample and maintain at $40 \mathrm{C}$.

Bottle baked at $350^{\circ} \mathrm{C}$ by laboratory. Filter sample using silver filter, chill and maintain at 40C. Filter may be retained for $\mathrm{LCO} 305$.

Bottle baked at $350^{\circ} \mathrm{C}$. Chill sample and maintain at $4{ }^{\circ} \mathrm{C}$. Bottle baked. Leave small air space. Add $2.0 \mathrm{~mL} \mathrm{H}_{2} \mathrm{SO}_{4}$ to $1 \mathrm{~L}$ (to $\mathrm{pH} 2$ ). Chill and maintain at $4^{\circ} \mathrm{C}$.

Retain sample on silver filter, chill and maintain at $4^{\circ} \mathrm{C}$. Record volume filtered on Log-Inv form, and on Petri dish. Bottle baked at $350^{\circ} \mathrm{C}$ by laboratory. Chill and maintain at $4^{\circ} \mathrm{C}$.

Bottle baked at $350^{\circ} \mathrm{C}$ by laboratory. Chill and maintain at $4{ }^{\circ} \mathrm{C}$.

Place strip in jar. Wrap jar in aluminum foil, freeze with dry ice, and ship expeditiously.

Collect on glass filter. Record volume filtered. Place filter in vial and wrap vial in aluminum foil. Freeze with dry ice and ship expeditiously. 


\section{Part 4: Analytical Services}





\section{Introduction}

Analytical Services available from the NWQL are presented in Table 4.2 which lists inorganic constituents, Table 4.3 which lists organic compounds and biological determinations. These tables contain information on sample classification (regular, limited, or special), cost, volume or weight of sample needed, sample designation, and detection level.

Quality assurance of organic substances data are enhanced by replicate analys is of approximately 10 percent of the samples submitted for analysis. Replicates are chosen at random from samples submitted for gross measures, polychlorinated biphenyls, reaeration constituents, and pesticides. In addition to providing assurance of values reported, replication provides the data necessary to establish analytical precision and recovery. The field effort is minimal, requiring only that a limited number of samples be submitted in duplicate.

Each analysis performed by GC/MS for the identification and quantification of purgeable, acid-extractable, base/neutral-extractable, and methylene chloride-extractable organic compounds includes the addition of four to six surrogates and a minimum of three internal standards. These efforts ensure compatibility of the NWQL data with protocols established by the U.S. Environmental Protection Agency for the analys is of "priority pollutants" and other substances that can be identified and quant itated by GC/MS. 


\section{Requests for Services}

All services available are listed so that when these services are needed they may be requested. However, not all services can be offered without limitations because of manpower constraints and availability of instrumentation.

Many "special" analyses are listed in the tables of determinations and schedules. If these analyses are requested, their availability must be discussed with the Organic or Inorganic Program Chief prior to submission of samples. The cost of special analyses may vary with the number of samples to be analyzed.

Procedures for acquiring "custom" analytical services are more formal than those required for other types of analytical services. Requests for these analyses require prior written approval of the Chief, Branch of Analytical Services. All "custom" analys is requests require the written acceptance of the necessary conditions by both the requestor and the NWQL before further programming is done or sample collection is started. Requestors of "custom" analyses must describe the need for the service, the intended use of the data, and specific needs for accuracy, precision and turnaround time. "Custom" analyses are applied research efforts and are more expensive due to equipment utilization or acquisition, and extra planning and analytical time required of laboratory personnel.

"Priority" analys is can be requested when circumstances warrant; however, a written request to the Organic or Inorganic Program Chief must be accepted and confirmed in writing to the requestor prior to collection and submission of samples. If agreement on conditions cannot be met, the Chief, Branch of Analytical Services will attempt to resolve the request, contacting the appropriate Regional Hydrologist if necessary. A surcharge of 50 percent or more will be added to the catalog price for these analyses if the work cannot be accomplished during regular work schedules. 
"Limited" analys is refers to analyses for which the ability to respond is constrained by manpower, instruments, or other considerations. Work in this category must be scheduled with the Organic or Inorganic Program Chief prior to submitting samples unless the requestor expects no definite time for completion of the work.

\section{Selection of analyses}

Analyses are requested by laboratory codes or schedules. The particular lab codes chosen should be selected based primarily on the detection levels desired. Laboratory personnel may opt to select a different analytical method than the one associated with the requested lab code if the detection limits are comparable. In other cases, an analyst may choose an alternate procedure in order to eliminate an interference or to measure a concentration higher than the upper limit of the method which was requested. Whenever an alternate procedure is selected, the laboratory codes on the laboratory analytical sheet will indicate the procedure actually used. However, if a procedure with a high detection level is requested and the concentration of the constituent being analyzed is below that detection level, the analyst will not select a more sensitive procedure without additional charge. The laboratory will assume responsibility for meeting any constraint specified in a schedule (e.g., detection level) and will select appropriate methodology.

The different classes of analyses, regular, limited, special, custom and priority should be considered when selecting an analysis. The glossary contains a definition of each of these classes which have been discussed on pages $4-2$ and $4-3$.

Precision should also be considered when choosing between two determinations. The precision data in Tables 5.2 and 5.3 .1 should be consulted before a final selection is made. Precision data are discussed in the Introduction to Part 5. 


\section{Laboratory Schedules}

Only a limited number of schedules (multiparameter combinations) are listed in the tables of determinations. Whenever possible, these schedules should be used rather than listing individual parameters. Some determinations, particularly organic, can be requested only by using a schedule. In such cases, the determinations are associated only with a SH (schedule) number and a LC (lab code) number is not provided in the Catalog.

All schedules containing lab codes for dissolved major cations or major anions or dissolved solids require that laboratory measurements of $\mathrm{pH}$ and specific conductance also be made. This requirement has been added to increase quality control within the analytical sections and should result in an overall decrease in the time needed for completion of the analyses. In order to meet this requirement, an "RU (raw untreated) bottle must be provided to the laboratory if major cations (dissolved) are requested. However, an "FU" (filtered, untreated) bottle will be substituted if an "RU" bottle is unavailable when major anions or dissolved solids are requested.

Different schedules can be created upon request; however, there are certain restrictions designed to speed the completion of analyses and insure that time-critical determinations are completed within the required time period. Generally, an individual schedule should contain parameters from only one category of sample. These categories are: water, inorganic (WI); water, major nutrient (WN); water, organic (WO); water, radiochemical (WR); bottom material, inorganic (BI); bottom material, organic (BO); and biological (BL). The inclusion of organic "gross measures" is permitted in both WI and WN schedules. Calculated parameters should not be requested separately unless listed in the catalog, because (with the exception of those listed in the catalog) all calculated values which can be produced from the data are automatically computed and printed in the analytical report. 
Priority Pollutants

The Federal Water Pollution Control Act Amendments of 1972 mandated the publication of a list of toxic pollutants. These substances (known as "priority pollutants", "consent decree pollutants", or "toxic pollutants") were selected on the basis of their presence in effluents, drinking water, and fish; their known or suspected carcinogenic and mutagenic properties; their toxicity to aquatic organisms and those (humans included) which could feed on those organisms.

Currently, there are 126 priority pollutants: 28 purgeable, 47 baseneutral extractable, 11 acid extractable, and 15 inorganic substances plus 25 pesticide residues. Of the 126 priority pollutants, the Central Laboratories System routinely determines 116 . The ten which are not included can be done upon request except, 2, 3, 7, 8-Tetrachlorodibenzop-dioxin and asbestos.

SH 1383 contains the base-neutral and acid extractable compounds (see page 4-23). SH 1390 contains the volatile organic compounds (see pages 428 and 4-29). SH 1324, SH 1364, LC 806, LC 807 and LC 808 contain the pesticide residues (see pages 4-27 and 4-33). SH 700 contains the inorganic substances. This schedule is not listed in the catalog, but contains lab codes 23, 80, 118, 147, 227, 236, 242, 250, 257, 267, 286, 288, and 296 (see pages 4-15, 4-16, and 4-17).

EPA List of 107 Organic Priority Pollutants

13 Acidic Compounds

4-Ch loro-3-methylpheno 1

Phenol

2-Nitropheno 1

4-Nitropheno 1

2,4-Dinitrophenol

Pentach lorophenol
2-Ch lorophenol

2,4-Dich lorophenol

2,4,6-Trich lorophenol

2,4-Dimethylpheno 1

4,6-Din itro-2-methy 1 pheno 1 
40 Neutral Compounds

\author{
1,2-Dich lorobenzene \\ 1,3-Dich lorobenzene \\ 1,4-Dich lorobenzene \\ Hexach loroethane \\ Hexachlorobutadiene \\ Hexach lorobenzene \\ 1,2,4-Trich lorobenzene \\ b is (2-Ch loroethoxy)methane \\ Naphthalene \\ 2-Ch loronaphtha lene \\ Isophorone \\ Nitrobenzene \\ 2,4-Din itrotoluene \\ 2,6-Dinitrotoluene \\ 4-Bromophenyl phenyl ether \\ bis(2-Ethylhexyl)phthalate \\ Di-n-octyl phthalate \\ Dimethyl phthalate \\ Diethyl phthalate \\ Di-n-butyl phthalate
}

6 Basic Compounds

3,3'-Dich lorobenzidine

Benzidine

1,2-Diphenylhydrazine
Acenaphthylene

Acenaphthene

Butyl benzyl phthalate

Fluorene

Fluoranthene

Chrysene

Pyrene

Phenanthrene

Anthracene

Benz (a) anthracene

Benzo(b)f luoranthene

Benzo(k)fluoranthene

Benzo(a)pyrene

Indeno $(1,2,3-c, d)$ pyrene

Dibenz $(a, h)$ anthracene

$\operatorname{Benzo}(g, h, i)$ perylene

4-Chloropheny 7 phenyl ether

bis(2-chloroethyl) ether

Hexach lorocyclopentadine

bis (2-Ch Tor isoprop 1)ether

28 Purgeable Compounds

Acrole in

Acrylonitrile

Benzene

Toluene

Ethylbenzene

Carbon tetrachloride

Ch lorobenzene

1,2-Dich loroethane

$1,1,1-$ Tr ich loroethane

1,1-Dich loroethane

1,1-Dich loroethylene

1,2,2-Trich loroethane

$1,1,2,2$-Tetrach loroethane

Chloroethane
2-Chloroethyl vinyl ether

Chloroform

1,2-Dich loropropane

1,3-Dich loropropene

Methylene chloride

Methyl chloride

Methy 1 bromide

Dich lorobromomethane

Ch lorod ibromomethane

Tetrach loroethylene

Trich lorethylene

Vinyl chloride

1,2-trans-Dich loroethylene

Bromoform 
20 Pesticides/PCBs/TCDD

\author{
Endosulfan \\ Endosulfan sulfate \\ Aldrin \\ Dieldrin \\ 4,4'-DDE \\ $4,4^{\prime}-$ DDD \\ Endrin \\ Endrin aldehyde \\ Heptachlor \\ Heptachlor epoxide \\ Chlordane
}

Toxaphene

Arochlor 1016

Arochlor 1221

Aroch lor 1232

Arochlor 1242

Arochlor 1248

Arochlor 1254

Arochlor 1260

2,3,7,8-Tetrachlorod ibenzop-diox in (TCDD)

\section{Computerized Schedule List}

In order to obtain the current list of schedules or recent changes in schedules, the following procedure may be used:

\section{SPN procedure}

A list of schedule numbers may be retrieved over PRIME and a search of schedules best suited to requestor needs can be made using menu driven program.

Retrievals can be obtained by login to LCOARV (National Water Quality Laboratory) and entering the command "SPN." A "user-id" will be established for anyone making a request by MAIL to DENADPOLCOARV.

Comments and questions may be addressed directly to DENADP 


\begin{tabular}{|c|c|c|c|c|c|c|c|}
\hline $\begin{array}{l}\text { Lab code } \\
\text { or } \\
\text { schedule }\end{array}$ & Class & $\begin{array}{l}\text { WATSTORE \& } \\
\text { method } \\
\text { code }\end{array}$ & $\begin{array}{c}\text { Price } \\
(\$)\end{array}$ & $\begin{array}{l}\text { Sample } \\
\text { volume }\end{array}$ & $\begin{array}{l}\text { Sample } \\
\text { desig- } \\
\text { nation }\end{array}$ & $\begin{array}{l}\text { Reporting } \\
\text { level }\end{array}$ & Remarks \\
\hline \multicolumn{8}{|c|}{ DISSOLVED } \\
\hline \multicolumn{8}{|c|}{ Inorganic constituents and physical properties } \\
\hline $\begin{array}{l}\text { LCO001 } \\
\text { LCOO70 } \\
\text { LC1284 } \\
\text { LCO077 } \\
\text { LCO112 }\end{array}$ & $\begin{array}{l}\text { Regular } \\
\text { Regular } \\
\text { Regular } \\
\text { Regular } \\
\text { Regular }\end{array}$ & $\begin{array}{l}71825 \text { A Acidity (mg/L as H) } \\
90410 \text { A Alkalinity (mg/L as } \mathrm{CaCO}_{3} \text { ) } \\
01106 \text { E Aluminum (ug/L as A1) } \\
01095 \text { A Antimony (ug/L as Sb) } \\
01000 \text { B Arsenic (ug/L as As) }\end{array}$ & $\begin{array}{r}10.07 \\
8.87 \\
15.84 \\
20.40 \\
20.40\end{array}$ & $\begin{array}{r}100 \mathrm{~mL} \\
100 \mathrm{~mL} \\
100 \mathrm{~mL} \\
50 \mathrm{~mL} \\
50 \mathrm{~mL}\end{array}$ & $\begin{array}{l}\text { RU } \\
\text { RU } \\
\text { FA } \\
\text { FA } \\
\text { FA }\end{array}$ & $\begin{array}{c}0.1 \\
1 \\
10 \\
1 \\
1\end{array}$ & \\
\hline $\begin{array}{l}\text { LCO007 } \\
\text { LCO170 } \\
\text { LC1183 } \\
\text { LC1246 } \\
\text { LC1258 }\end{array}$ & $\begin{array}{l}\text { Regular } \\
\text { Regular } \\
\text { Regular } \\
\text { Regular } \\
\text { Limited }\end{array}$ & $\begin{array}{l}01005 \text { B Barium (ug/L as Ba) } \\
01010 \text { A Bery11ium (ug/L as Be) } \\
01020 \text { B Boron (ug/L as B) } \\
71870 \text { B Bromide (mg/L as Br) } \\
71870 \text { F Bromide (mg/L as Br) }\end{array}$ & $\begin{array}{r}12.45 \\
12.45 \\
12.00 \\
8.75 \\
\text { SH1101 }\end{array}$ & $\begin{array}{l}25 \mathrm{~mL} \\
25 \mathrm{~mL} \\
25 \mathrm{~mL} \\
25 \mathrm{~mL} \\
50 \mathrm{~mL}\end{array}$ & $\begin{array}{l}\text { FA } \\
\text { FA } \\
F A, F U \\
\text { FU } \\
\text { FCU }\end{array}$ & $\begin{array}{l}100 \\
10 \\
10 \\
.01 \\
.01\end{array}$ & $\mathrm{~J}$ \\
\hline $\begin{array}{l}\text { LC1554 } \\
\text { LCO126 } \\
\text { LC1250 } \\
\text { LCO012 } \\
\text { LCO831 }\end{array}$ & $\begin{array}{l}\text { Regular } \\
\text { Regular } \\
\text { Limited } \\
\text { Regular } \\
\text { Limited }\end{array}$ & $\begin{array}{l}01025 \text { F Cadmium (ug/L as Cd) } \\
01025 \text { A Cadmium (ug/L as Cd) } \\
01025 \text { E Cadmium (ug/L as Cd) } \\
00915 \text { C Calcium (mg/L as Ca) } \\
00915 \text { B Calcium (mg/L as Ca) }\end{array}$ & $\begin{array}{r}18.54 \\
9.52 \\
27.00 \\
6.22 \\
10.89\end{array}$ & $\begin{array}{l}50 \mathrm{~mL} \\
25 \mathrm{~mL} \\
25 \mathrm{~mL} \\
50 \mathrm{~mL} \\
50 \mathrm{~mL}\end{array}$ & $\begin{array}{l}F A \\
F A \\
F A B \\
F A \\
F A\end{array}$ & $\begin{array}{l}1 \\
10 \\
.1 \\
.1 \\
.01\end{array}$ & A \\
\hline $\begin{array}{l}\text { LCO015 } \\
\text { LC1259 } \\
\text { LCO727 } \\
\text { LC1251 } \\
\text { LCO016 }\end{array}$ & $\begin{array}{l}\text { Regular } \\
\text { Limited } \\
\text { Regular } \\
\text { Limited } \\
\text { Regular }\end{array}$ & $\begin{array}{l}00940 \text { E Chloride (mg/L as Cl) } \\
00940 \text { I Chloride (mg/L as Cl) } \\
01030 \text { F Chromium (ug/L as Cr) } \\
01030 \text { D Chromium (ug/L as Cr) } \\
01032 \text { A Chromium, hexavalent (ug/L as Cr) }\end{array}$ & $\begin{array}{r}6.35 \\
\text { SH1101 } \\
12.00 \\
27.00 \\
20.08\end{array}$ & $\begin{array}{r}25 \mathrm{~mL} \\
50 \mathrm{~mL} \\
25 \mathrm{~mL} \\
25 \mathrm{~mL} \\
200 \mathrm{~mL}\end{array}$ & $\begin{array}{l}\text { FU } \\
\text { FCU } \\
\text { FA } \\
\text { FAB } \\
\text { FA }\end{array}$ & $1_{1}^{.01}$ & J \\
\hline $\begin{array}{l}\text { LC1556 } \\
\text { LCO148 } \\
\text { LC1252 } \\
\text { LC1558 } \\
\text { LCO151 }\end{array}$ & $\begin{array}{l}\text { Regular } \\
\text { Regular } \\
\text { Limited } \\
\text { Regular } \\
\text { Regular }\end{array}$ & $\begin{array}{l}01035 \mathrm{~F} \text { Cobalt (ug/L as Co) } \\
01035 \text { A Cobalt (ug/L as Co) } \\
01035 \mathrm{E} \text { Cobalt (ug/L as Co) } \\
01040 \mathrm{~F} \text { Copper (ug/L as Cu) } \\
01040 \text { A Copper (ug/L as Cu) }\end{array}$ & $\begin{array}{r}18.54 \\
9.52 \\
27.00 \\
18.54 \\
9.52\end{array}$ & $\begin{array}{l}50 \mathrm{~mL} \\
25 \mathrm{~mL} \\
25 \mathrm{~mL} \\
50 \mathrm{~mL} \\
25 \mathrm{~mL}\end{array}$ & $\begin{array}{l}\text { FA } \\
\text { FA } \\
\text { FAB } \\
\text { FA } \\
\text { FA }\end{array}$ & ${ }_{10}^{1.5}$ & A \\
\hline $\begin{array}{l}\text { LC1253 } \\
\text { LCO880 } \\
\text { LCO024 } \\
\text { LCO031 }\end{array}$ & $\begin{array}{l}\text { Limited } \\
\text { Regular } \\
\text { Regular } \\
\text { Regular }\end{array}$ & $\begin{array}{l}01040 \text { E Copper (ug/L as Cu) } \\
00723 \text { A Cyanide (mg/L as CN) } \\
71820 \text { A Density (g/mL at } 200 \mathrm{C}) \\
00950 \text { B Fluoride }(\mathrm{mg} / \mathrm{L} \text { as } \mathrm{F})\end{array}$ & $\begin{array}{r}27.00 \\
23.05 \\
13.70 \\
8.09\end{array}$ & $\begin{array}{r}25 \mathrm{~mL} \\
50 \mathrm{~mL} \\
100 \mathrm{~mL} \\
50 \mathrm{~mL}\end{array}$ & $\begin{array}{l}\text { FAB } \\
\text { LCO880 } \\
\text { FU } \\
\text { FU }\end{array}$ & $\begin{array}{l}.5 \\
.01 \\
.990 \\
.1\end{array}$ & \\
\hline
\end{tabular}

(Remarks: A, atomic absorption graphite furnace procedure replaces chelation-extraction procedure providing the same minimum reporting level with better precision. J, determined by ion chromatography, a single charge is made for the six 1 ab codes.) 
Table 4.2.--Inorganic Analyses--Continued

\begin{tabular}{|c|c|c|c|c|c|c|c|}
\hline $\begin{array}{l}\text { Lab code } \\
\text { or } \\
\text { scheduie }\end{array}$ & Class & $\begin{array}{l}\text { WATSTORE \& } \\
\text { method Parameter name and unit of measurement } \\
\text { code }\end{array}$ & $\begin{array}{l}\text { Price } \\
(\$)\end{array}$ & $\begin{array}{l}\text { Samp le } \\
\text { volume }\end{array}$ & $\begin{array}{l}\text { Sample } \\
\text { desig- } \\
\text { nation }\end{array}$ & $\begin{array}{l}\text { Report ing } \\
\text { leve } 1\end{array}$ & Remarks \\
\hline \multicolumn{8}{|c|}{ DISSOLVED--Continued } \\
\hline \multicolumn{8}{|c|}{ Inorganic constituents and physical properties--Continued } \\
\hline $\begin{array}{l}\text { LC1260 } \\
\text { LC1202 } \\
\text { LCO172 } \\
\text { LC1560 } \\
\text { LCO191 }\end{array}$ & $\begin{array}{l}\text { Limited } \\
\text { Regular } \\
\text { Regular } \\
\text { Regular } \\
\text { Regular }\end{array}$ & $\begin{array}{l}00950 \text { D Fluoride (mg/L as F) } \\
71865 \text { D Iodide (mg/L as I) } \\
01046 \text { C Iron (ug/L as Fe) } \\
01049 \text { F Lead (ug/L as Pb) } \\
01049 \text { A Lead (ug/L as Pb) }\end{array}$ & $\begin{array}{r}\text { SH1101 } \\
21.78 \\
5.17 \\
18.54 \\
9.52\end{array}$ & $\begin{array}{l}50 \mathrm{~mL} \\
50 \mathrm{~mL} \\
25 \mathrm{~mL} \\
50 \mathrm{~mL} \\
25 \mathrm{~mL}\end{array}$ & $\begin{array}{l}\text { FCU } \\
\text { FU } \\
\text { FA } \\
\text { FA } \\
\text { FA }\end{array}$ & $\begin{array}{l}.01 \\
10 \\
5 \\
100\end{array}$ & J \\
\hline $\begin{array}{l}\text { LC1254 } \\
\text { LCO039 } \\
\text { LCO040 } \\
\text { LC0832 } \\
\text { LC0042 }\end{array}$ & $\begin{array}{l}\text { Limited } \\
\text { Regular } \\
\text { Regular } \\
\text { Regular } \\
\text { Regular }\end{array}$ & $\begin{array}{l}01049 \text { E Lead (ug/L as } \mathrm{Pb} \text { ) } \\
01130 \text { A Lithium (ug/L as Li) } \\
00925 \text { B Magnesium (mg/L as Mg) } \\
00925 \text { A Magnesium (mg/L as Mg) } \\
01056 \text { A Manganese (ug/L as } \mathrm{Mn})\end{array}$ & $\begin{array}{r}27.00 \\
5.78 \\
6.93 \\
10.89 \\
5.17\end{array}$ & $\begin{array}{l}25 \mathrm{~mL} \\
25 \mathrm{~mL} \\
50 \mathrm{~mL} \\
50 \mathrm{~mL} \\
25 \mathrm{~mL}\end{array}$ & $\begin{array}{l}\text { FAB } \\
\text { FA } \\
\text { FA } \\
\text { FA } \\
\text { FA }\end{array}$ & $10^{.5} .1$ & \\
\hline $\begin{array}{l}\text { LC1255 } \\
\text { LCO226 } \\
\text { LCO110 } \\
\text { LC1562 } \\
\text { LCO197 }\end{array}$ & $\begin{array}{l}\text { Limited } \\
\text { Regular } \\
\text { Regular } \\
\text { Regular } \\
\text { Regular }\end{array}$ & $\begin{array}{l}01056 \text { D Manganese (ug/L as Mn) } \\
71890 \text { B Mercury (ug/L as Hg) } \\
01060 \text { B Molybdenum (ug/L as Mo) } \\
01065 \text { F Nickel (ug/L as Ni) } \\
01065 \text { A Nickel (ug/L as Ni) }\end{array}$ & $\begin{array}{r}27.00 \\
20.40 \\
19.35 \\
18.54 \\
9.52\end{array}$ & $\begin{array}{r}25 \mathrm{~mL} \\
200 \mathrm{~mL} \\
200 \mathrm{~mL} \\
50 \mathrm{~mL} \\
25 \mathrm{~mL}\end{array}$ & $\begin{array}{l}\text { FAB } \\
\text { FAM } \\
\text { FA } \\
\text { FA } \\
\text { FA }\end{array}$ & $\stackrel{1}{1}_{100}^{.2}$ & A \\
\hline $\begin{array}{l}\text { LC1256 } \\
\text { LCO301 } \\
\text { LCO830 } \\
\text { LC0268 } \\
\text { LC1261 }\end{array}$ & $\begin{array}{l}\text { Limited } \\
\text { Regular } \\
\text { Regular } \\
\text { Regular } \\
\text { Limited }\end{array}$ & $\begin{array}{l}01065 \text { D Nicke } 1 \text { (ug/L as } N i) \\
00608 \text { B Nitrogen, ammonia (mg/L as } N) \\
00608 \text { A Nitrogen, ammonia (mg/L as } N) \\
00623 \text { A Nitrogen, ammonia plus organic (mg/L as } N \text { ) } \\
00618 \text { D Nitrogen, nitrate (mg/L as } N \text { ) }\end{array}$ & $\begin{array}{r}27.00 \\
4.73 \\
7.37 \\
12.49 \\
\text { SH1 } 101\end{array}$ & $\begin{array}{r}25 \mathrm{~mL} \\
250 \mathrm{~mL} \\
250 \mathrm{~mL} \\
250 \mathrm{~mL} \\
50 \mathrm{~mL}\end{array}$ & $\begin{array}{l}F A B \\
F C \\
F C \\
F C \\
\text { FCU }\end{array}$ & $\begin{array}{l}.01 \\
.002 \\
.2 \\
.01\end{array}$ & $\mathrm{~J}$ \\
\hline $\begin{array}{l}L C 0160 \\
\text { LCO827 } \\
\text { LCO228 } \\
\text { LCO826 } \\
\text { LCO128 }\end{array}$ & $\begin{array}{l}\text { Regular } \\
\text { Regular } \\
\text { Regular } \\
\text { Regular } \\
\text { Regular }\end{array}$ & $\begin{array}{l}00613 \text { B Nitrogen, nitrite (mg/L as } N) \\
00613 \text { A Nitrogen, nitrite (mg/L as } N) \\
00631 \text { B Nitrogen, nitrite plus nitrate (mg/L as } N) \\
00631 \text { A Nitrogen, nitrite plus nitrate (mg/L as } N) \\
00666 \text { B Phosphorus (mg/L as P) }\end{array}$ & $\begin{array}{r}4.73 \\
7.37 \\
4.73 \\
7.37 \\
13.25\end{array}$ & $\begin{array}{l}250 \mathrm{~mL} \\
250 \mathrm{~mL} \\
250 \mathrm{~mL} \\
250 \mathrm{~mL} \\
250 \mathrm{~mL}\end{array}$ & $\begin{array}{l}F C \\
F C \\
F C \\
F C \\
F C\end{array}$ & $\begin{array}{l}.01 \\
.001 \\
.1 \\
.01 \\
.01\end{array}$ & \\
\hline $\begin{array}{l}\text { LCO829 } \\
\text { LC0279 } \\
\text { LCO162 }\end{array}$ & $\begin{array}{l}\text { Regular } \\
\text { Regular } \\
\text { Regular }\end{array}$ & $\begin{array}{l}00666 \text { A Phosphorus (mg/L as P) } \\
00677 \text { A Phosphorus, hydrolyzable plus orthophosphate (mg/L as P) } \\
00671 \text { B Phosphorus, orthophosphate (mg/L as P) }\end{array}$ & $\begin{array}{r}20.79 \\
12.05 \\
4.73\end{array}$ & $\begin{array}{l}250 \mathrm{~mL} \\
250 \mathrm{~mL} \\
250 \mathrm{~mL}\end{array}$ & $\begin{array}{l}\text { FC } \\
\text { FC } \\
\text { FC }\end{array}$ & $\begin{array}{l}.001 \\
.01 \\
.01\end{array}$ & \\
\hline
\end{tabular}

(Remarks: A, atomic absorption graphite furnace procedure replaces chelation-extraction procedure providing the same minimum reporting level with better precision. J, determined by ion chromatography, a single charge is made for the six lab codes.) 
Table 4.2.--Inganic Analyses--Continued

\begin{tabular}{|c|c|c|c|c|c|c|c|c|}
\hline $\begin{array}{l}\text { Lab code } \\
\text { or } \\
\text { schedule }\end{array}$ & Class & $\begin{array}{l}\text { WATSTORE \& } \\
\text { method } \\
\text { code }\end{array}$ & Parameter name and unit of measurement & $\begin{array}{c}\text { Price } \\
(\$)\end{array}$ & $\begin{array}{l}\text { Sample } \\
\text { volume }\end{array}$ & $\begin{array}{l}\text { Sample } \\
\text { desig- } \\
\text { nation }\end{array}$ & $\begin{array}{l}\text { Reporting } \\
\text { leve } 1\end{array}$ & Remarks \\
\hline
\end{tabular}

\section{DISSOLVED--Continued}

Inorganic constituents and physical properties--Continued

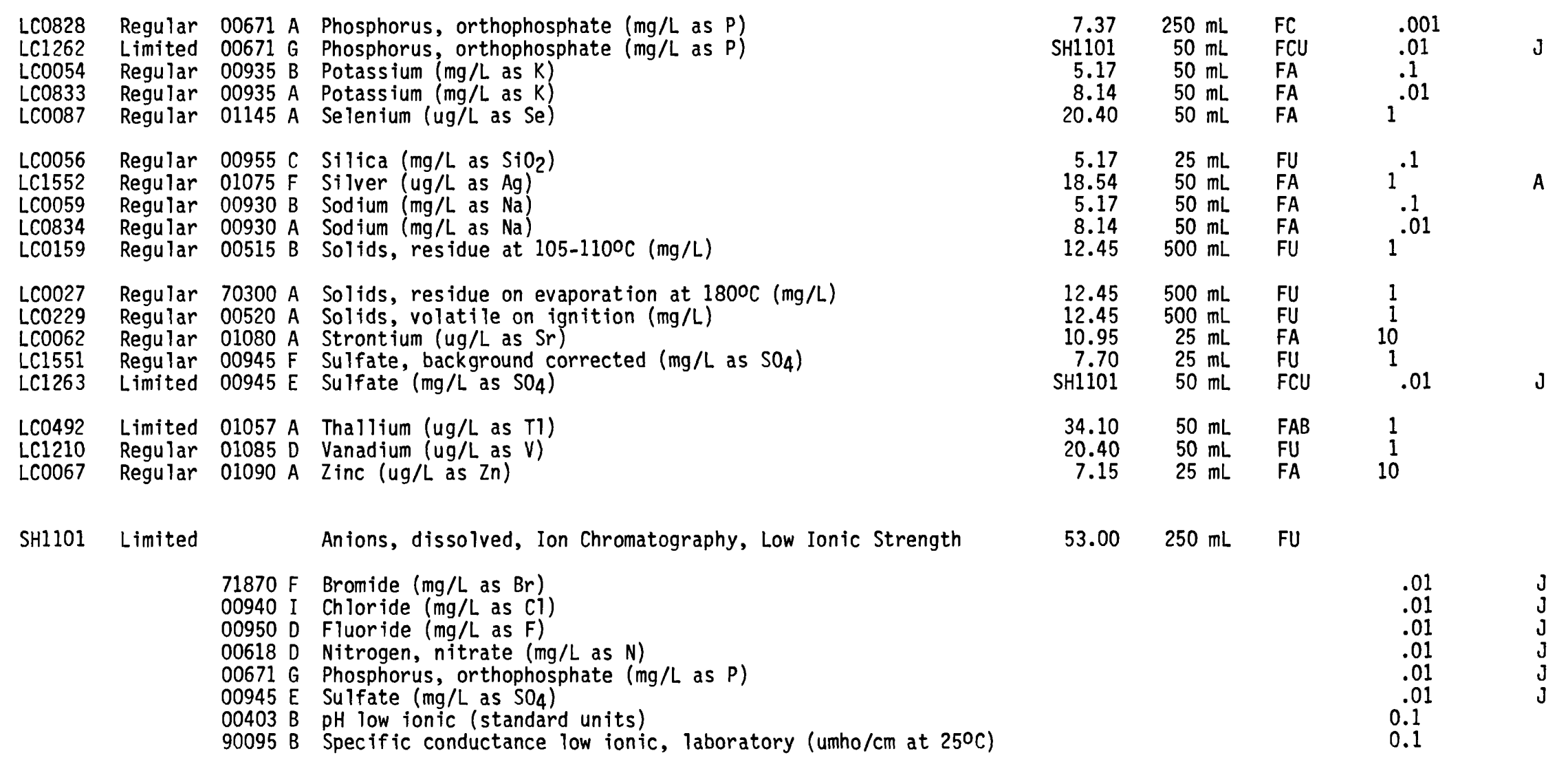

\footnotetext{
(Remarks: A, atomic absorption graphite furnace procedure replaces chelation-extraction procedure providing the same minimum reporting level with better precision. J, determined by ion chromatography, a single charge is made for the six lab codes. Specific conductance must 
Table 4.2.--Inorganic Analyses--Continued

\begin{tabular}{|c|c|c|c|c|c|c|c|c|}
\hline $\begin{array}{l}\text { Lab code } \\
\text { or } \\
\text { schedule }\end{array}$ & Class & $\begin{array}{l}\text { WATSTORE \& } \\
\text { method } \\
\text { code }\end{array}$ & Parameter name and unit of measurement & $\begin{array}{c}\text { Price } \\
(\mu)\end{array}$ & $\begin{array}{l}\text { Sample } \\
\text { volume }\end{array}$ & $\begin{array}{l}\text { Sample } \\
\text { desig- } \\
\text { nation }\end{array}$ & $\begin{array}{l}\text { Reporting } \\
\text { level }\end{array}$ & Remarks \\
\hline
\end{tabular}

\section{DISSOLVED--Continued}

Inorganic constituents and physical properties--Continued

SH1102 Regular

Cations, dissolved, Inductively Coupled Plasma, Low Ionic Strength

$35.00 \quad 250 \mathrm{~mL} \quad \mathrm{FA}$

00915 E Calcium (mg/L as Ca)

01046 E Iron, LL (ug/L as Fe)

00925 D Magnesium ( $\mathrm{mg} / \mathrm{L}$ as $\mathrm{Mg}$ )

01056 E Manganese (ug/L as Mn)

$00403 \mathrm{~A} \mathrm{pH}$, laboratory, reported to the nearest unit (standard units)

$00955 \mathrm{E} \mathrm{Silica} \mathrm{(mg/L} \mathrm{as} \mathrm{SiO}_{2}$ )

$00930 \mathrm{D}$ Sodium (mg/L as $\mathrm{Na}$ )

90095 B. Specific conductance, laboratory (umho/cm at $25^{\circ} \mathrm{C}$ )

35.00 $250 \mathrm{~mL}$
SH1106 Regular Nutrients, dissolved, Low Ionic Strength samples only
00631 A Nitrogen, nitrite plus nitrate (mg/L as N)
SH1106 Regular Nutrients, dissolved, Low Ionic Strength samples on
00631 A Nitrogen, nitrite plus nitrate (mg/L as N)
00613 A Nitrogen, nitrite ( $\mathrm{mg} / \mathrm{L}$ as $\mathrm{N}$ )
00671 A Phosphorus, orthophosphate $(\mathrm{mg} / \mathrm{L}$ as $\mathrm{P})$
00608 A Nitrogen, ammonia (mg/L as N)

SH0146 Regular Trace metals, dissolved, Inductively Coupled Plasma

Detection levels are improved if the specific conductance is low. The specific conductance of the sample must be less than 6,000 umho/cm if this schedule is requested. Reporting levels at 2,000 and 6,000 umho/cm are 1 isted.

\begin{tabular}{|c|c|}
\hline $\begin{array}{l}\text { Below } \\
2,000 \\
\end{array}$ & $\begin{array}{c}2,000 \text { to } \\
6,000\end{array}$ \\
\hline .02 & .06 \\
\hline 3 & 9 \\
\hline $1^{.01}$ & $3^{.03}$ \\
\hline 0.1 & 0.1 \\
\hline $\begin{array}{l}.01 \\
.2\end{array}$ & $\begin{array}{r}.03 \\
.6\end{array}$ \\
\hline 1 & 1 \\
\hline
\end{tabular}

00915 D Calcium (mg/L as Ca)

01046 D Iron (ug/L as Fe)

00925 C Magnesium (mg/L as $\mathrm{Mg}$ )

01056 C Manganese (ug/L as Mn)

$00403 \mathrm{~A} \mathrm{pH}$, laboratory, reported to the nearest 0.1 unit (standard units)

00955 D Silica (mg/L as $\mathrm{SiO}_{2}$ )

$00930 \mathrm{C}$ Sodium (mg/L as $\mathrm{Na}$ )

90095 A Specific conductance, laboratory (umho/cm at $25^{\circ} \mathrm{C}$ )
$5.00 \quad 250 \mathrm{~mL} \quad F C$

$$
\begin{aligned}
& { }^{0.02} \\
& 3^{.01} \\
& 0.1 \\
& 0.1 \\
& .2 \\
& 0.1
\end{aligned}
$$

$$
\begin{aligned}
& .001 \\
& .001 \\
& .001 \\
& .002
\end{aligned}
$$

$29.92 \quad 100 \mathrm{~mL} \quad \mathrm{FA}$


Table 4.2.--Inorganic Analyses--Continued

\begin{tabular}{|c|c|c|c|c|c|c|c|c|}
\hline $\begin{array}{l}\text { Lab code } \\
\text { or } \\
\text { schedule }\end{array}$ & Class & $\begin{array}{l}\text { WATSTORE \& } \\
\text { method } \\
\text { code }\end{array}$ & Parameter name and unit of measurement & $\begin{array}{c}\text { Price } \\
(\$)\end{array}$ & $\begin{array}{l}\text { Sample } \\
\text { volume }\end{array}$ & $\begin{array}{l}\text { Sample } \\
\text { desig- } \\
\text { nation }\end{array}$ & $\begin{array}{l}\text { Reporting } \\
\text { level }\end{array}$ & Remarks \\
\hline
\end{tabular}

\section{DISSOLVED--Continued}

\section{Inorganic constituents and physical properties--Continued}

SH1043 Regular Trace metals, dissolved, Inductively Coupled Plasma

$78.82 \quad 100 \mathrm{~mL} \quad F A$

Detection levels are improved if the specific conductance is low. The specific conductance of the sample must be less than 6,000 umho/cm if this schedule is requested. Reporting levels at 2,000 and 6,000 umho/cm are listed.

01005 C Barium (ug/L as Ba)

01010 B Beryllium (ug/L as Be)

01025 D Cadmium (ug/L as Cd)

00915 D Calcium (mg/L as $\mathrm{Ca})$

01035 C Cobalt (ug/L as Co)

01030 E Chromium (ug/L as $\mathrm{Cr}$ )

01040 C Copper (ug/L as Cu)

01046 D Iron (ug/L as Fe)

$01049 \mathrm{C}$ Lead (ug/L as $\mathrm{Pb}$ )

01130 B Lithium (ug/L as Li)

\begin{tabular}{|c|c|c|}
\hline & $\begin{array}{l}\text { Be low } \\
2,000 \\
\end{array}$ & $\begin{array}{l}2,000 \\
6,000 \\
\end{array}$ \\
\hline & $3_{3}^{2} .02$ & $\begin{array}{l}6 \\
1.5 \\
3 \\
9^{.06}\end{array}$ \\
\hline & $\begin{array}{r}5 \\
10 \\
3 \\
10 \\
4\end{array}$ & $\begin{array}{r}15 \\
30 \\
9 \\
30 \\
12\end{array}$ \\
\hline & $\begin{array}{c}10^{.01} \\
1 \\
10 \\
1\end{array}$ & $\begin{array}{c}30^{.03} \\
3 \\
30 \\
1\end{array}$ \\
\hline nho $/ \mathrm{cm}$ at $25^{\circ} \mathrm{C}$ ) & $\begin{array}{l}.^{.01} \\
1_{1}^{.2} \\
0.5\end{array}$ & $\begin{array}{l}.03 \\
3^{.6} \\
1 \\
1.5\end{array}$ \\
\hline & $\begin{array}{l}6 \\
3\end{array}$ & $\begin{array}{r}18 \\
9\end{array}$ \\
\hline
\end{tabular}

$00925 \mathrm{C}$ Magnesium (mg/ $\mathrm{L}$ as $\mathrm{Mg}$ )

$01065 \mathrm{E} \mathrm{Nickel} \mathrm{(ug/L}$ as Ni)

01056 C Manganese (ug/L as Mn)

01060 A Molybdenum ( $\mathrm{ug} / \mathrm{L}$ as Mo)

$00403 \mathrm{~A} \mathrm{pH}$, laboratory (standard units)

$00955 \mathrm{D}$ Silica (mg/L as $\mathrm{SiO}_{2}$ )

00930 C Sodium (mg/L as $\mathrm{Na}$ )

01075 C Silver (ug/L as $\mathrm{Ag}$ )

90095 A Specific conductance, laboratory (umho/cm at $25^{\circ} \mathrm{C}$ )

01080 B Strontium (ug/L as Sr)

01085 B Vanadium (ug/L as V)

$01090 \mathrm{~B}$ Zinc (ug/L as $\mathrm{Zn}$ ) 
Table 4.2.--Inorganic Analyses--Continued

\begin{tabular}{|c|c|c|c|c|c|c|c|}
\hline $\begin{array}{l}\text { Lab code } \\
\text { or } \\
\text { schedule }\end{array}$ & Class & Parameter name and unit of measurement & $\begin{array}{l}\text { Price } \\
(\$)\end{array}$ & $\begin{array}{l}\text { Sample } \\
\text { volume }\end{array}$ & $\begin{array}{l}\text { Sample } \\
\text { desig- } \\
\text { nation }\end{array}$ & $\begin{array}{l}\text { Reporting } \\
\text { leve } 1\end{array}$ & Remarks \\
\hline \multicolumn{8}{|c|}{ SUSPENDED } \\
\hline \multicolumn{8}{|c|}{ Inorganic constituents and physical properties--Continued } \\
\hline $\begin{array}{l}\text { LCO169 } \\
\text { LCO049 }\end{array}$ & $\begin{array}{l}\text { Regular } \\
\text { Regular }\end{array}$ & $\begin{array}{l}00530 \text { B Solids, residue at } 105-1100 \mathrm{C}(\mathrm{mg} / \mathrm{L}) \\
00535 \text { A Solids, volatile on ignition (mg/L) }\end{array}$ & $\begin{array}{l}13.70 \\
13.64\end{array}$ & $\begin{array}{l}500 \mathrm{~mL} \\
500 \mathrm{~mL}\end{array}$ & $\begin{array}{l}\text { LC0169 } \\
\text { LC0169 }\end{array}$ & $\frac{1}{1}$ & \\
\hline \multicolumn{8}{|c|}{ TOTAL RECOVERABLE } \\
\hline \multicolumn{8}{|c|}{ Inorganic constituents and physical properties } \\
\hline $\begin{array}{l}\text { LCO654 } \\
\text { LCO124 } \\
\text { LC1283 }\end{array}$ & $\begin{array}{l}\text { Regular } \\
\text { Regular } \\
\text { Regular }\end{array}$ & $\begin{array}{l}00000 \text { A Digestion procedure, } \mathrm{HCl} \text { water } \\
00000 \text { A Digestion procedure, EPA } \\
01105 \text { C Aluminum (ug/L as Ai) }\end{array}$ & $\begin{array}{l}18.60 \\
32.15 \\
15.84\end{array}$ & $\begin{array}{l}50 \mathrm{~mL} \\
100 \mathrm{~mL} \\
200 \mathrm{~mL}\end{array}$ & $\begin{array}{l}\text { RA } \\
\text { RAE } \\
\text { RA }\end{array}$ & $\begin{array}{l}-- \\
\overline{10}\end{array}$ & $\begin{array}{l}B \\
C \\
B\end{array}$ \\
\hline $\begin{array}{l}\text { LCO234 } \\
\text { LCO236 } \\
\text { LC1286 } \\
\text { LC0131 } \\
\text { LC1555 }\end{array}$ & $\begin{array}{l}\text { Regular } \\
\text { Regular } \\
\text { Regular } \\
\text { Regular } \\
\text { Regular }\end{array}$ & $\begin{array}{l}01007 \text { A Barium (ug/L as Ba) } \\
01012 \text { A Bery 1 lium (ug/L as Be) } \\
01022 \text { B Boron (ug/L as B) } \\
01027 \text { A Cadmium (ug/L as Cd) } \\
01027 \text { F Cadmium (ug/L as Cd) }\end{array}$ & $\begin{array}{r}12.45 \\
12.45 \\
12.00 \\
9.52 \\
18.54\end{array}$ & $\begin{array}{l}50 \mathrm{~mL} \\
50 \mathrm{~mL} \\
50 \mathrm{~mL} \\
50 \mathrm{~mL} \\
50 \mathrm{~mL}\end{array}$ & $\begin{array}{l}\text { RA } \\
\text { RA } \\
\text { RA } \\
\text { RA } \\
\text { RA }\end{array}$ & $\begin{array}{r}100 \\
10 \\
10 \\
10 \\
1\end{array}$ & $\begin{array}{l}B \\
B \\
E \\
E \\
A, B\end{array}$ \\
\hline $\begin{array}{l}\text { LCO244 } \\
\text { LCO324 } \\
\text { LC0726 } \\
\text { LC0149 } \\
\text { LC1557 }\end{array}$ & $\begin{array}{l}\text { Regular } \\
\text { Regular } \\
\text { Regular } \\
\text { Regular } \\
\text { Regular }\end{array}$ & $\begin{array}{l}00916 \text { B Calcium, USGS digestion procedure (mg/L as Ca) } \\
00916 \text { A Calcium, EPA digestion procedure (mg/L as Ca) } \\
01034 \text { D Chromium (ug/L as Cr) } \\
01037 \text { A Cobalt (ug/L as Co) } \\
01037 \text { F Cobalt (ug/L as Co) }\end{array}$ & $\begin{array}{r}7.15 \\
7.15 \\
12.00 \\
9.52 \\
18.54\end{array}$ & $\begin{array}{l}50 \mathrm{~mL} \\
50 \mathrm{~mL} \\
50 \mathrm{~mL} \\
50 \mathrm{~mL} \\
50 \mathrm{~mL}\end{array}$ & $\begin{array}{l}\text { RA } \\
\text { RAE } \\
\text { RA } \\
\text { RA } \\
\text { RA }\end{array}$ & $1^{.1}$ & $\begin{array}{l}B \\
C \\
B \\
B \\
A, B\end{array}$ \\
\hline $\begin{array}{l}\text { LCO156 } \\
\text { LC1559 } \\
\text { LCO023 } \\
\text { LCO189 } \\
\text { LCO192 }\end{array}$ & $\begin{array}{l}\text { Regular } \\
\text { Regular } \\
\text { Regular } \\
\text { Regular } \\
\text { Regular }\end{array}$ & $\begin{array}{l}01042 \text { A Copper (ug/L as Cu) } \\
01042 \text { F Copper (ug/L as Cu) } \\
00720 \text { A Cyanide (mg/L as CN) } \\
01045 \text { B Iron (ug/L as Fe) } \\
01051 \text { A Lead (ug/L as Pb) }\end{array}$ & $\begin{array}{r}9.52 \\
18.54 \\
23.05 \\
5.17 \\
9.52\end{array}$ & $\begin{array}{l}50 \mathrm{~mL} \\
50 \mathrm{~mL} \\
50 \mathrm{~mL} \\
50 \mathrm{~mL} \\
50 \mathrm{~mL}\end{array}$ & $\begin{array}{l}\text { RA } \\
\text { RA } \\
\text { LCO023 } \\
\text { RA } \\
\text { RA }\end{array}$ & ${ }_{10}^{10} 101$ & $\begin{array}{l}B \\
A, B \\
B \\
B\end{array}$ \\
\hline $\begin{array}{l}\text { LC1561 } \\
\text { LCO277 } \\
\text { LC0261 } \\
\text { LCO325 }\end{array}$ & $\begin{array}{l}\text { Regular } \\
\text { Regular } \\
\text { Regular } \\
\text { Regular }\end{array}$ & $\begin{array}{l}01051 \text { F Lead (ug/L as } \mathrm{Pb} \text { ) } \\
01132 \text { A Lithium (ug/L as Li) } \\
00927 \text { B Magnesium, USGS digestion procedure (mg/L as } \mathrm{Mg}) \\
00927 \text { A Magnesium, EPA digestion procedure (mg/L as } \mathrm{Mg})\end{array}$ & $\begin{array}{r}18.54 \\
5.17 \\
7.15 \\
7.15\end{array}$ & $\begin{array}{l}50 \mathrm{~mL} \\
50 \mathrm{~mL} \\
50 \mathrm{~mL} \\
50 \mathrm{~mL}\end{array}$ & $\begin{array}{l}\text { RA } \\
\text { RA } \\
\text { RA } \\
\text { RAE }\end{array}$ & $\begin{array}{r}5 \\
10 \\
.1 \\
.1\end{array}$ & $\begin{array}{l}A, B \\
B \\
B \\
C\end{array}$ \\
\hline
\end{tabular}

(Remarks: A, atomic absorption graphite furnace procedure replaces chelation-extraction procedure providing the same minimum reporting level with better precision. B, LCO654 is automatically called in when any combination of total recoverable lab codes (except LCO323, 325, 327, and 929) is requested, and this one-time charge is added. C, LCO124 is automatically called in when any combination of EPA procedure 
Table 4.2.--Inorganic Analyses--Continued

\begin{tabular}{|c|c|c|c|c|c|c|c|c|}
\hline $\begin{array}{l}\text { Lab code } \\
\text { or } \\
\text { schedu }\end{array}$ & Class & $\begin{array}{l}\text { WATSTORE \& } \\
\text { method } \\
\text { code }\end{array}$ & Parameter name and unit of measurement & $\begin{array}{c}\text { Price } \\
(\$)\end{array}$ & $\begin{array}{l}\text { Sample } \\
\text { vo lume }\end{array}$ & $\begin{array}{l}\text { Sample } \\
\text { desig- } \\
\text { nation }\end{array}$ & $\begin{array}{l}\text { Reporting } \\
\text { leve } 1\end{array}$ & Remarks \\
\hline
\end{tabular}

TOTAL RECOVERABLE--Continued

\section{Inorganic constituents and physical properties--Contimed}

\begin{tabular}{|c|c|c|c|c|c|c|c|}
\hline $\begin{array}{l}\text { LCO041 } \\
\text { LC0227 } \\
\text { LC0265 } \\
\text { LC0198 } \\
\text { LC1563 }\end{array}$ & $\begin{array}{l}\text { Regular } \\
\text { Regular } \\
\text { Regular } \\
\text { Regular } \\
\text { Regular }\end{array}$ & $\begin{array}{l}01055 \text { A Manganese (ug/L as Mm) } \\
71900 \text { B Mercury (ug/L as Hg) } \\
01062 \text { A Molybdenum (ug/L as Mo) } \\
01067 \text { A Nickel (ug/L as Ni) } \\
01067 \text { F Nicket (ug/L as Ni) }\end{array}$ & $\begin{array}{r}5.17 \\
27.50 \\
19.35 \\
9.52 \\
18.54\end{array}$ & $\begin{array}{r}50 \mathrm{~mL} \\
200 \mathrm{~mL} \\
200 \mathrm{~mL} \\
50 \mathrm{~mL} \\
50 \mathrm{~mL}\end{array}$ & $\begin{array}{l}\text { RA } \\
\text { RAM } \\
\text { RA } \\
\text { RA } \\
\text { RA }\end{array}$ & $\stackrel{1}{10}_{100}^{.1}$ & $\begin{array}{l}B \\
B \\
A, B\end{array}$ \\
\hline $\begin{array}{l}\text { LCO321 } \\
\text { LCO327 } \\
\text { LC1553 } \\
\text { LC0320 } \\
\text { LCO326 }\end{array}$ & $\begin{array}{l}\text { Regular } \\
\text { Regular } \\
\text { Regular } \\
\text { Regular } \\
\text { Regular }\end{array}$ & $\begin{array}{l}00937 \text { B Potassium, USGS digestion procedure (mg/L as } \mathrm{K} \text { ) } \\
00937 \text { A Potassium, EPA digestion procedure (mg/L as } \mathrm{K} \text { ) } \\
01077 \text { F Si lver (ug/L as Ag) } \\
00929 \text { B Sodium, USGS digestion procedure (mg/L as } \mathrm{Na}) \\
00929 \text { A Sodium, EPA digestion procedure (mg/L as } \mathrm{Na})\end{array}$ & $\begin{array}{r}5.17 \\
5.17 \\
18.54 \\
5.17 \\
5.17\end{array}$ & $\begin{array}{l}50 \mathrm{~mL} \\
50 \mathrm{~mL} \\
50 \mathrm{~mL} \\
50 \mathrm{~mL} \\
50 \mathrm{~mL}\end{array}$ & $\begin{array}{l}\text { RA } \\
\text { RAE } \\
\text { RA } \\
\text { RA } \\
\text { RAE }\end{array}$ & $1_{1}^{.1}$ & $\begin{array}{l}B \\
C \\
A, B \\
B \\
C\end{array}$ \\
\hline $\begin{array}{l}\text { LCO290 } \\
\text { LCO296 }\end{array}$ & $\begin{array}{l}\text { Regular } \\
\text { Regular }\end{array}$ & $\begin{array}{l}01082 \text { A Strontium (ug/L as Sr) } \\
01092 \text { A Zinc (ug/L as } \mathrm{Zn} \text { ) }\end{array}$ & $\begin{array}{r}10.95 \\
7.15\end{array}$ & $\begin{array}{l}50 \mathrm{~mL} \\
50 \mathrm{~mL}\end{array}$ & $\begin{array}{l}\text { RA } \\
\text { RA }\end{array}$ & $\begin{array}{l}10 \\
10\end{array}$ & $\begin{array}{l}\text { B } \\
\text { B }\end{array}$ \\
\hline \multicolumn{8}{|l|}{ TOTAL } \\
\hline \multicolumn{8}{|c|}{ Inorganic constituents and physical properties } \\
\hline $\begin{array}{l}\text { LCO001 } \\
\text { LC1266 } \\
\text { LCO070 } \\
\text { LC1270 } \\
\text { LCO080 }\end{array}$ & $\begin{array}{l}\text { Regular } \\
\text { Regular } \\
\text { Regular } \\
\text { Regular } \\
\text { Regular }\end{array}$ & $\begin{array}{l}71825 \text { A Acidity (mg/L as H) } \\
71825 \text { B Acidity, 2nd deriv., (mg/L as H) } \\
90410 \text { A Alkalinity (mg/L as CaCO3/) } \\
90410 \text { B Alkalinity, 2nd deriv., (mg/L as } \mathrm{CaCO}_{3} \text { ) } \\
01097 \text { A Antimony (ug/L as Sb) }\end{array}$ & $\begin{array}{r}10.07 \\
26.86 \\
8.87 \\
26.86 \\
21.20\end{array}$ & $\begin{array}{r}100 \mathrm{~mL} \\
75 \mathrm{~mL} \\
100 \mathrm{~mL} \\
75 \mathrm{~mL} \\
200 \mathrm{~mL}\end{array}$ & $\begin{array}{l}\text { RU } \\
\text { RU } \\
\text { RU } \\
\text { RU } \\
\text { RAH }\end{array}$ & $\begin{array}{l}0.1 \\
0.01 \\
1 \\
0.5 \\
1\end{array}$ & $\begin{array}{l}L \\
L\end{array}$ \\
\hline $\begin{array}{l}\text { LCO118 } \\
\text { LCO020 } \\
\text { LCO123 } \\
\text { LCO836 } \\
\text { LCO084 }\end{array}$ & $\begin{array}{l}\text { Regular } \\
\text { Regular } \\
\text { Regular } \\
\text { Regular } \\
\text { Regular }\end{array}$ & $\begin{array}{l}01002 \text { B Arsenic (ug/L as As) } \\
00080 \text { A Color (platinum-cobalt units) } \\
00610 \text { B Nitrogen, ammonia (mg/L as } N \text { ) } \\
00610 \text { A Nitrogen, ammonia (mg/L as } N \text { ) } \\
00625 \text { A Nitrogen, ammonia plus organic (mg/L as } N \text { ) }\end{array}$ & $\begin{array}{r}21.20 \\
5.34 \\
4.73 \\
7.37 \\
12.49\end{array}$ & $\begin{array}{l}50 \mathrm{~mL} \\
100 \mathrm{~mL} \\
250 \mathrm{~mL} \\
250 \mathrm{~mL} \\
250 \mathrm{~mL}\end{array}$ & $\begin{array}{l}\text { RAH } \\
\mathrm{RCB} \\
\mathrm{RC} \\
\mathrm{RC} \\
\mathrm{RC}\end{array}$ & $\begin{array}{l}1 \\
.01 \\
.002 \\
.2\end{array}$ & \\
\hline $\begin{array}{l}\text { LCO302 } \\
\text { LCO840 } \\
\text { LCO304 } \\
\text { LCO839 } \\
\text { LCO076 }\end{array}$ & $\begin{array}{l}\text { Regular } \\
\text { Regular } \\
\text { Regular } \\
\text { Regular } \\
\text { Regular }\end{array}$ & $\begin{array}{l}00615 \text { B Nitrogen, nitrite (mg/L as } \mathrm{N}) \\
00615 \text { A Nitrogen, nitrite (mg/L as } \mathrm{N}) \\
00630 \text { B Nitrogen, nitrite plus nitrate (mg/L as } \mathrm{N}) \\
00630 \text { A Nitrogen, nitrite plus nitrate }(\mathrm{mg} / \mathrm{L} \text { as } \mathrm{N}) \\
00340 \text { B Oxygen demand, chemical, .25N } \mathrm{K}_{2} \mathrm{Cr}_{207}(\mathrm{mg} / \mathrm{L})\end{array}$ & $\begin{array}{r}4.73 \\
7.37 \\
4.73 \\
7.37 \\
14.58\end{array}$ & $\begin{array}{l}250 \mathrm{~mL} \\
250 \mathrm{~mL} \\
250 \mathrm{~mL} \\
250 \mathrm{~mL} \\
100 \mathrm{~mL}\end{array}$ & $\begin{array}{l}\mathrm{RC} \\
\mathrm{RC} \\
\mathrm{RC} \\
\mathrm{RC} \\
\mathrm{LCOOO}\end{array}$ & $0_{10}^{.01} .001$ & \\
\hline
\end{tabular}

Remarks: A, atomic absorption graphite furnace procedure replaces chelation-extraction procedure providing the same minimum reporting (Remarks: A, atomic absorption graphite furnace procedure replaces chelation-extraction procedure providing the same minimum reporting
level with better precision. B, LCO654 is automatically called in when any combination of total recoverable lab codes (except LC0323, 325 ,

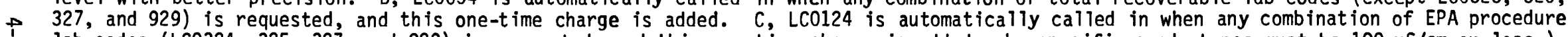
$\stackrel{i}{\mathrm{r}}$ lab codes (LCO324, 325, 327, and 929) is requested, and this one-time charge is added. $L$, specific conductance must be 100 uS/cm or less.) 
Table 4.2.--Inorganic Analyses--Continued

\begin{tabular}{|c|c|c|c|c|c|c|c|c|}
\hline $\begin{array}{l}\text { Lab code } \\
\text { or } \\
\text { schedule }\end{array}$ & Class & $\begin{array}{l}\text { WATSTORE \& } \\
\text { method } \\
\text { code }\end{array}$ & Parameter name and unit of measurement & $\begin{array}{c}\text { Price } \\
(\$)\end{array}$ & $\begin{array}{l}\text { Sample } \\
\text { volume }\end{array}$ & $\begin{array}{l}\text { Sample } \\
\text { desig- } \\
\text { nation }\end{array}$ & $\begin{array}{l}\text { Reporting } \\
\text { level }\end{array}$ & Remarks \\
\hline
\end{tabular}

\section{TOTAL--Continued}

Inorganic constituents and physical properties--Continued

\begin{tabular}{|c|c|c|c|c|c|c|c|c|}
\hline $\begin{array}{l}\text { LCO068 } \\
\text { LC1286 } \\
\text { LCO129 } \\
\text { LCO837 } \\
\text { LC0282 }\end{array}$ & $\begin{array}{l}\text { Regular } \\
\text { Regular } \\
\text { Regular } \\
\text { Regular } \\
\text { Regular }\end{array}$ & $\begin{array}{ll}00403 & \text { A } \\
00403 & B \\
00665 & B \\
00665 & A \\
00678 & \text { A }\end{array}$ & $\begin{array}{l}\text { pH, laboratory (standard units) } \\
\text { pH, laboratory, low ionic strength (standard units) } \\
\text { Phosphorus (mg/L as P) } \\
\text { Phosphorus (mg/L as P) } \\
\text { Phosphorus, hydrolyzable plus orthophosphate (mg/L as P) }\end{array}$ & $\begin{array}{r}2.92 \\
5.50 \\
12.05 \\
20.79 \\
12.05\end{array}$ & $\begin{array}{r}25 \mathrm{~mL} \\
75 \mathrm{~mL} \\
250 \mathrm{~mL} \\
250 \mathrm{~mL} \\
250 \mathrm{~mL}\end{array}$ & $\begin{array}{l}\mathrm{RU} \\
\mathrm{RU} \\
\mathrm{RC} \\
\mathrm{RC} \\
\mathrm{RC}\end{array}$ & $\begin{array}{l}.1 \\
.1 \\
.01 \\
.001 \\
.01\end{array}$ & \\
\hline $\begin{array}{l}\text { LC0297 } \\
\text { LC0838 } \\
\text { LC0286 } \\
\text { LCO165 } \\
\text { LCO085 }\end{array}$ & $\begin{array}{l}\text { Regular } \\
\text { Regular } \\
\text { Regular } \\
\text { Regular } \\
\text { Regular }\end{array}$ & $\begin{array}{l}70507 \text { A } \\
70507 \text { B } \\
01147 \text { A } \\
00500 \text { A } \\
00505 \text { A }\end{array}$ & $\begin{array}{l}\text { Phosphorus, orthophosphate (mg/L as P) } \\
\text { Phosphorus, orthophosphate (mg/L as P) } \\
\text { Selenium (ug/L as Se) } \\
\text { Solids, residue at } 105-110^{\circ} \mathrm{C}(\mathrm{mg} / \mathrm{L}) \\
\text { Solids, volatile on ignition (mg/L) }\end{array}$ & $\begin{array}{r}4.73 \\
7.37 \\
21.20 \\
12.45 \\
13.69 \\
5.50\end{array}$ & $\begin{array}{r}250 \mathrm{~mL} \\
250 \mathrm{~mL} \\
100 \mathrm{~mL} \\
500 \mathrm{~mL} \\
500 \mathrm{~mL} \\
50 \mathrm{~mL}\end{array}$ & $\begin{array}{l}\mathrm{RC} \\
\mathrm{RC} \\
\mathrm{RAH} \\
\mathrm{RU} \\
\mathrm{RU} \\
\mathrm{R}\end{array}$ & $\begin{array}{l}.01 \\
.001 \\
1 \\
1 \\
.1\end{array}$ & \\
\hline $\begin{array}{l}\text { LCO069 } \\
\text { LC1269 }\end{array}$ & $\begin{array}{l}\text { Regular } \\
\text { Regular }\end{array}$ & $\begin{array}{l}90095 \text { A } \\
90095 \text { B }\end{array}$ & $\begin{array}{l}\text { Specific conductance, laboratory (umho/cm at } 25^{\circ} \mathrm{C} \text { ) } \\
\text { Specific conductance, laboratory, low ionic strength } \\
\text { (umho/cm at } 25^{\circ} \mathrm{C} \text { ) }\end{array}$ & $\begin{array}{l}2.92 \\
5.50\end{array}$ & $\begin{array}{l}50 \mathrm{~mL} \\
50 \mathrm{~mL}\end{array}$ & $\begin{array}{l}\text { RU } \\
\text { RU }\end{array}$ & 1.1 & \\
\hline $\begin{array}{l}\text { LCO089 } \\
\text { LCO050 }\end{array}$ & $\begin{array}{l}\text { Regular } \\
\text { Regular }\end{array}$ & $\begin{array}{l}00745 \mathrm{~A} \\
00076 \mathrm{~A}\end{array}$ & $\begin{array}{l}\text { Sulfide (mg/L as S) } \\
\text { Turbidity (nephelometric-turbidity units) }\end{array}$ & $\begin{array}{r}12.45 \\
5.34\end{array}$ & $\begin{array}{r}250 \mathrm{~mL} \\
50 \mathrm{~mL}\end{array}$ & $\begin{array}{l}\text { LCO089 } \\
\text { LCO050 }\end{array}$ & .5 & \\
\hline SH1108 & Regular & $\begin{array}{l}\text { Nutrients } \\
00610 \text { A } \\
70507 \text { B } \\
00630 \text { A } \\
00615 \text { A }\end{array}$ & $\begin{array}{l}\text {, total, Low Ionic Strength samples only } \\
\text { Nitrogen, ammonia (mg/L as } N \text { ) } \\
\text { Phosphorus, orthophosphate (mg/L as } P \text { ) } \\
\text { Nitrogen, nitrite plus nitrate (mg/L as } N) \\
\text { Nitrogen, nitrite (mg/L as } N \text { ) }\end{array}$ & 25.00 & $250 \mathrm{~mL}$ & RC & $\begin{array}{l}.002 \\
.001 \\
.01 \\
.001\end{array}$ & \\
\hline \multicolumn{9}{|c|}{ BOTTOM MATERIAL-RECOVERABLE } \\
\hline \multicolumn{9}{|c|}{ Inorganic constituents and physical properties } \\
\hline $\begin{array}{l}\text { LC1184 } \\
\text { LC0647 } \\
\text { LC1282 } \\
\text { LC0521 } \\
\text { LC0522 }\end{array}$ & $\begin{array}{l}\text { Regular } \\
\text { Regular } \\
\text { Regular } \\
\text { Regular } \\
\text { Regular }\end{array}$ & $\begin{array}{l}00000 \text { A } \\
00000 \text { A } \\
01108 \text { C } \\
01008 \text { A } \\
01013 \text { A }\end{array}$ & $\begin{array}{l}\text { Preparation of bottom material } \\
\text { Digestion procedure for bottom material } \\
\text { Aluminum, dry wt. (ug/g as } A 1 \text { ) } \\
\text { Barium, dry wt. (ug/g as } \mathrm{Ba} \text { ) } \\
\text { Beryllium, dry wt. (ug/g as Be) }\end{array}$ & $\begin{array}{l}18.46 \\
36.80 \\
15.84 \\
19.80 \\
19.80\end{array}$ & $\begin{array}{ll}10 & \mathrm{~g} \\
10 & \mathrm{~g} \\
10 \mathrm{~g} \\
10 \mathrm{~g} \\
10 \mathrm{~g}\end{array}$ & $\begin{array}{l}C U \\
C U \\
C U \\
C U\end{array}$ & $\begin{array}{r}-- \\
10 \\
10\end{array}$ & $\begin{array}{l}D \\
E \\
E \\
E \\
E\end{array}$ \\
\hline $\begin{array}{l}\text { LC1285 } \\
\text { LC0502 } \\
\text { LC0696 } \\
\text { LCO505 } \\
\text { LC0506 }\end{array}$ & $\begin{array}{l}\text { Regular } \\
\text { Regular } \\
\text { Regular } \\
\text { Regular } \\
\text { Regular }\end{array}$ & $\begin{array}{ll}01023 & \text { C } \\
01028 & \text { B } \\
00917 & \text { A } \\
01029 & \text { B } \\
01038 & \text { B }\end{array}$ & $\begin{array}{l}\text { Boron, dry wt. (ug/g as B) } \\
\text { Cadmium, dry wt. (ug/g as Cd) } \\
\text { Calcium, dry wt. (mg/kg as Ca) } \\
\text { Chromium, dry wt. (ug/g as Cr) } \\
\text { Cobalt, dry wt. (ug/g as Co) }\end{array}$ & $\begin{array}{l}12.00 \\
15.35 \\
18.42 \\
19.80 \\
15.35\end{array}$ & $\begin{array}{ll}10 & \mathrm{~g} \\
10 & \mathrm{~g} \\
10 & \mathrm{~g} \\
10 & \mathrm{~g} \\
10 & \mathrm{~g}\end{array}$ & $\begin{array}{l}C U \\
C U \\
C U \\
C U\end{array}$ & $\begin{array}{r}10 \\
1 \\
10 \\
1 \\
5\end{array}$ & $\begin{array}{l}E \\
E \\
E \\
E \\
E\end{array}$ \\
\hline
\end{tabular}

(Remarks: D, LC1184 is automatically called in for any combination of the following 1ab codes: LC0511, 515, 517, and 597, and this one$512,518,519,521,522,523,530,541,696,697,698,699,1282$, and 1285 , and this one-time charge is added.) 
Table 4.2.---Inorganic Analyses--Continued

\begin{tabular}{|c|c|c|c|c|c|c|c|c|}
\hline $\begin{array}{l}\text { Lab code } \\
\text { or } \\
\text { schedule }\end{array}$ & Class & $\begin{array}{l}\text { WATSTORE \& } \\
\text { method } \\
\text { code }\end{array}$ & Parameter name and unit of measurement & $\begin{array}{c}\text { Price } \\
(\$)\end{array}$ & $\begin{array}{l}\text { Sample } \\
\text { volume }\end{array}$ & $\begin{array}{l}\text { Sample } \\
\text { desig- } \\
\text { nation }\end{array}$ & $\begin{array}{c}\text { Reporting } \\
\text { leve } 1\end{array}$ & Remarks \\
\hline
\end{tabular}

\section{BOTTOM MATERIAL-RECOVERABLE--Cont inued}

\section{Inorganic constituents and physical properties--continued}

$\begin{array}{llll}\text { LC0507 } & \text { Regular } & 01043 \text { B Copper, dry wt. (ug/g as Cu) } \\ \text { LC0190 } & \text { Regular } & 01170 \text { B Iron, dry wt. (ug/g as Fe) } \\ \text { LC0510 } & \text { Regular } & 01052 \text { B Lead, dry wt. (ug/g as Pb) } \\ \text { LC0541 } & \text { Regular } & 01133 \text { A Lithium, dry wt. (ug/g as Li) } \\ \text { LC0697 } & \text { Regular } & 00924 \text { A Magnesium, dry wt. (mg/kg as Mg) } \\ & & & \\ \text { LC0512 } & \text { Regular } & 01053 \text { A Manganese, dry wt. (ug/g as Mn) } \\ \text { LC0511 } & \text { Regular } & 71921 \text { A Mercury, dry wt. (ug/g as Hg) } \\ \text { LC0523 } & \text { Regular } & 01063 \text { A Molybdenum, dry wt. (ug/g as Mo) } \\ \text { LC0519 } & \text { Regular } & 01068 \text { B Nickel, dry wt. (ug/g as Ni) } \\ \text { LC0698 } & \text { Regular } & 00938 \text { A Potassium, dry wt. (mg/kg as K) } \\ & & \\ \text { LC0699 } & \text { Regular } & 00934 \text { A Sodium, dry wt. (mg/kg as Na) } \\ \text { LC0530 } & \text { Regular } & 01083 \text { A Strontium, dry wt. (ug/g as Sr) } \\ \text { LC0518 } & \text { Regular } & 01093 \text { A Zinc, dry wt. (ug/g as Zn) }\end{array}$

\begin{tabular}{|c|c|c|c|}
\hline $\begin{array}{l}15.35 \\
15.35 \\
15.35 \\
15.35 \\
18.42\end{array}$ & $\begin{array}{l}10 \mathrm{~g} \\
10 \mathrm{~g} \\
10 \mathrm{~g} \\
10 \mathrm{~g} \\
10 \mathrm{~g}\end{array}$ & $\begin{array}{l}C U \\
C U \\
C U \\
C U \\
C U\end{array}$ & $\begin{array}{r}1 \\
1 \\
10 \\
1 \\
10\end{array}$ \\
\hline $\begin{array}{l}15.35 \\
34.76 \\
20.46 \\
15.35 \\
15.35\end{array}$ & $\begin{array}{ll}10 & \mathrm{~g} \\
10 & \mathrm{~g} \\
10 & \mathrm{~g} \\
10 & \mathrm{~g} \\
10 & \mathrm{~g}\end{array}$ & $\begin{array}{l}\mathrm{CU} \\
\mathrm{CU} \\
\mathrm{CU} \\
\mathrm{CU} \\
\mathrm{CU}\end{array}$ & $\begin{array}{c}1 \\
.01 \\
10 \\
10\end{array}$ \\
\hline $\begin{array}{l}15.35 \\
18.42 \\
15.35\end{array}$ & $\begin{array}{l}10 \mathrm{~g} \\
10 \mathrm{~g} \\
10 \mathrm{~g}\end{array}$ & $\begin{array}{l}\mathrm{CU} \\
\mathrm{CU} \\
\mathrm{CU}\end{array}$ & $\begin{array}{r}10 \\
1 \\
1\end{array}$ \\
\hline
\end{tabular}

\section{BOTTOM MATERIAL-TOTAL}

\section{Inorganic constituents and physical properties}

\begin{tabular}{|c|c|c|c|c|c|c|}
\hline $\begin{array}{l}\text { LCO534 } \\
\text { LCO597 } \\
\text { LCO904 } \\
\text { LCO524 } \\
\text { LCO513 }\end{array}$ & $\begin{array}{l}\text { Regular } \\
\text { Regular } \\
\text { Regular } \\
\text { Regular } \\
\text { Regular }\end{array}$ & $\begin{array}{l}01098 \text { A Antimony, dry wt. (ug/g as Sb) } \\
01003 \text { C Arsenic, dry wt. (ug/g as As) } \\
00611 \text { A Nitrogen, ammonia, dry wt. (mg/kg as } \mathrm{N} \text { ) } \\
00633 \text { A Nitrogen, nitrite plus nitrate, dry wt. (mg/kg as N) }\end{array}$ & $\begin{array}{l}34.76 \\
34.76 \\
16.72 \\
21.89 \\
21.89\end{array}$ & $\begin{array}{ll}10 \mathrm{~g} \\
10 \mathrm{~g} \\
10 \mathrm{~g} \\
10 \mathrm{~g} \\
10 \mathrm{~g}\end{array}$ & $\begin{array}{l}C U \\
C U \\
C U \\
C C\end{array}$ & $D$ \\
\hline $\begin{array}{l}\text { LC0532 } \\
\text { LCO515 } \\
\text { LCO517 } \\
\text { LCO516 }\end{array}$ & $\begin{array}{l}\text { Regular } \\
\text { Regular } \\
\text { Regular } \\
\text { Regular }\end{array}$ & $\begin{array}{l}00339 \text { A Oxygen demand, chemical, dry wt. (mg/kg) } \\
00668 \text { B Phosphorus, dry wt. (mg/kg as P) } \\
01148 \text { A Selenium, dry wt. (ug/g as Se) } \\
00496 \text { A Solids, volatile on ignition, dry wt. (mg/kg) }\end{array}$ & $\begin{array}{l}32.18 \\
19.30 \\
34.54 \\
23.00\end{array}$ & $\begin{array}{ll}10 & \mathrm{~g} \\
10 & \mathrm{~g} \\
10 \mathrm{~g} \\
10 & \mathrm{~g}\end{array}$ & 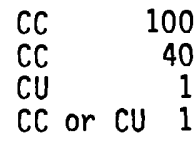 & $\begin{array}{l}D \\
D\end{array}$ \\
\hline
\end{tabular}

(Remarks: D, LC1184 is automatically called in for any combination of the following lab codes: LC0511, 515, 517, and 597, and this one-time charge is added. $E$, LCO647 is automatically called in for any combination of the following codes: LCO190, 502, 505, 506, 507, 510, 512, $518,519,521,522,523,530,541,696,697,698,699,1282$, and 1285, and this one-time charge is added. 
Table 4.2.--Radiochemical analysis

\begin{tabular}{|c|c|c|c|c|c|c|c|c|}
\hline Schedule & $\begin{array}{l}\text { Lab } \\
\text { code }\end{array}$ & $\begin{array}{l}\text { WATSTORE } \\
\text { and Method } \\
\text { code }\end{array}$ & Parameter name and unit of measurement & $\begin{array}{l}\text { Price } \\
(\$)\end{array}$ & $\begin{array}{l}\text { Sample } \\
\text { volume }\end{array}$ & $\begin{array}{l}\text { Sample } \\
\text { desig- } \\
\text { nation }\end{array}$ & $\begin{array}{l}\text { Reporting } \\
\text { level }\end{array}$ & $\begin{array}{l}2 \text { SPE } \\
\text { code }\end{array}$ \\
\hline \multicolumn{9}{|c|}{ Gross alpha and gross beta } \\
\hline SH0606 & $\begin{array}{l}\text { LCO444 } \\
\text { LC1393 } \\
\text { LCO445 } \\
\text { LCO455 } \\
\text { LCO446 } \\
\text { LC1395 } \\
\text { LCO447 } \\
\text { LCO456 }\end{array}$ & $\begin{array}{l}80030 \text { A } \\
80050 \text { A } \\
03515 \text { A } \\
80040 \text { A } \\
80060 \text { A } \\
03516 \text { A }\end{array}$ & 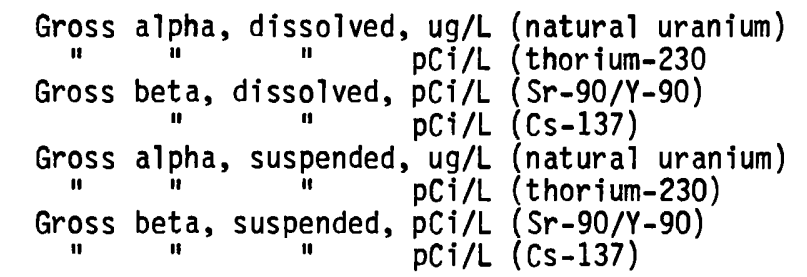 & 98.75 & $2 \mathrm{~L}$ & RUR & $\begin{array}{l}0.4 \\
0.4 \\
0.4 \\
0.4 \\
0.4 \\
0.4 \\
0.4 \\
0.4\end{array}$ & $\begin{array}{r}852 \\
1394 \\
858 \\
856 \\
859 \\
1396 \\
857 \\
860\end{array}$ \\
\hline SH0609 & $\begin{array}{l}\text { This sc } \\
\text { LC1355 } \\
\text { LC1399 } \\
\text { LC1356 } \\
\text { LC1357 } \\
\text { LCO446 } \\
\text { LC1395 } \\
\text { LC0447 } \\
\text { LC0456 }\end{array}$ & $\begin{array}{l}\text { edule is to } \\
80030 \mathrm{C} \\
80050 \mathrm{C} \\
03515 \mathrm{C} \\
80040 \mathrm{~A} \\
80060 \mathrm{~A} \\
03516 \mathrm{~A}\end{array}$ & 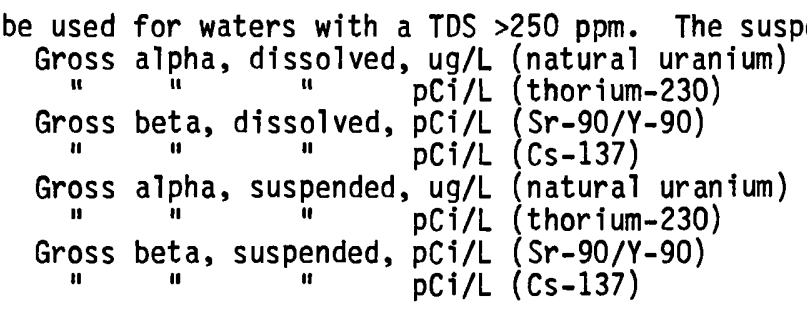 & $\begin{array}{c}d \text { analysis } \\
122.50\end{array}$ & $\begin{array}{l}\text { is the } \\
2 \mathrm{~L}\end{array}$ & $\begin{array}{l}\text { same regardless } \\
\text { RUR }\end{array}$ & $\begin{array}{l}\text { of TDS. } \\
0.4 \\
0.4 \\
0.4 \\
0.4 \\
0.4 \\
0.4 \\
0.4 \\
0.4\end{array}$ & $\begin{array}{r}1370 \\
1400 \\
1371 \\
1372 \\
859 \\
1396 \\
857 \\
860\end{array}$ \\
\hline SH0456 & $\begin{array}{l}\text { LC0800 } \\
\text { LC1397 } \\
\text { LC0793 } \\
\text { LC0798 }\end{array}$ & $\begin{array}{l}80030 \text { B } \\
80050 \text { B } \\
03515 \text { B }\end{array}$ & 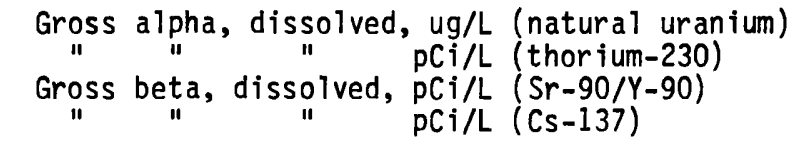 & 60.00 & $2 \mathrm{~L}$ & FAR & $\begin{array}{l}0.4 \\
0.4 \\
0.4 \\
0.4\end{array}$ & $\begin{array}{r}853 \\
1398 \\
855 \\
854\end{array}$ \\
\hline SHO458 & $\begin{array}{l}\text { The fol } \\
\text { LC1358 } \\
\text { LC1445 } \\
\text { LC1359 } \\
\text { LC1360 }\end{array}$ & $\begin{array}{l}\text { owing are to } \\
80030 \mathrm{D} \\
80050 \mathrm{D} \\
03515 \mathrm{D}\end{array}$ & 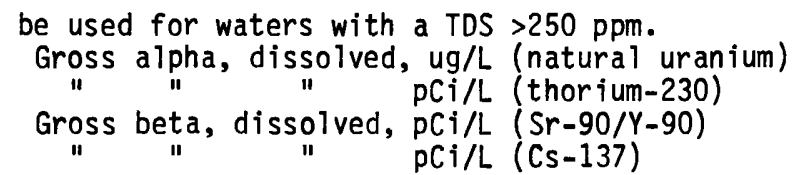 & 75.00 & $2 \mathrm{~L}$ & FAR & $\begin{array}{l}0.4 \\
0.4 \\
0.4 \\
0.4\end{array}$ & $\begin{array}{l}1373 \\
1446 \\
1374 \\
1375\end{array}$ \\
\hline
\end{tabular}

Bottles - Acid rinsed polyethylene.

For samples requiring filtration and acidification, use 0.45 um filter and acidify to $\mathrm{pH}<2$ using concentrated nitric acid (usually $3 \mathrm{~mL}$ of concentrated $\mathrm{HNO}_{3} / \mathrm{L}$ are sufficient). 
Table 4.2.--Radiochenical analysis--Continued

‡్

\begin{tabular}{|c|c|c|c|c|c|c|c|c|}
\hline Schedule & $\begin{array}{l}\text { Lab } \\
\text { code }\end{array}$ & $\begin{array}{l}\text { WATSTORE } \\
\text { and Method } \\
\text { code }\end{array}$ & Parameter name and unit of measurement & $\begin{array}{c}\text { Price } \\
(\$)\end{array}$ & $\begin{array}{l}\text { Sample } \\
\text { volume }\end{array}$ & $\begin{array}{l}\text { Sample } \\
\text { desig- } \\
\text { nation }\end{array}$ & $\begin{array}{l}\text { Reporting } \\
\text { level }\end{array}$ & $\begin{array}{l}2 \text { SPE } \\
\text { code }\end{array}$ \\
\hline
\end{tabular}

\section{Gross alpha and gross beta--Continued}

SH1131

LC1518
LC1520
LC1522
LC1524

Gross alpha, bottom materia1, $\mathrm{pCi} / \mathrm{g}$

Gross alpha, bottom material, $\mathrm{pCi} / \mathrm{g}$ (thorium-230)

Gross beta, bottom material, $\mathrm{pCi} / \mathrm{g}$ ( $\mathrm{Cs}-137)$

Gross beta, bottom material, $\mathrm{pCi} / \mathrm{g}(\mathrm{Sr}-90)$

Ganma

LC0211 99450 A Gross gamma scan, suspended, PCi/L

LC0443 99452 A Gross gamma scan, dissolved, $\mathrm{pCi} / \mathrm{L}$

LC0212 99451 A Gross gamma scan, bottom material,

total, dry wt., $\mathrm{pCi} / \mathrm{g}$

Lead-210

LC1503 17503 B

LC1549 17507 C

Polonium-210

LC1505 19503 A Polonium-210, dissolved, PCi/L

LC1543 -.-- Polonium-210, suspended, $\mathrm{pCi} / \mathrm{g}$

LC1545 19507 A Polonium-210, bottom material, pCi/g

Radium and radon

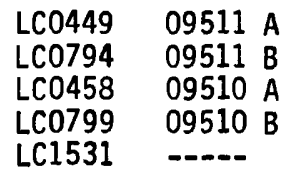

Lead-210, by gamma, bottom material, $\mathrm{pCi} / \mathrm{g}$

Lead-210 (dating) by gamma, dry wt., $\mathrm{pCi} / \mathrm{g}$

Cs -137 is also reported as $p C i / g$ dry weight with

$0.02 \mathrm{pCi} / \mathrm{g}$.

Lead-210, dissolved, $\mathrm{PCi} / \mathrm{L}$

Radium-226 by de-emanation, dissolved, $\mathrm{pCi} / \mathrm{L}$

Radium-226 by de-emanation, dissolved, $\mathrm{DCi} / \mathrm{L}$

Radium-226 by precipitation, dissolved, $\mathrm{pCi} / \mathrm{L}$

Radium-226 by precipitation, dissolved, $\mathrm{pCi} / \mathrm{L}$

Radium-226, suspended, $\mathrm{PC} i / g$
68.75

CU

$\begin{array}{ll}6.0 & 1519 \\ 6.0 & 1521 \\ 3.0 & 1523 \\ 3.0 & 1525\end{array}$

100.00
87.50

100.00

$\begin{array}{rl}7 & 1 \\ 7 & L \\ 100 & 9\end{array}$

RUR Varies with nuclides 874

FAR Varies with nuclides 877

$100 \mathrm{~g}$

CU Varies with nuclides 875

$\begin{array}{rrlll}197.50 & 100 \mathrm{~g} & \text { CU } & 0.1 & 876 \\ & & & & \\ 98.75 & 1 \mathrm{~L} & \text { FAR } & 1.5 & 1504 \\ 111.25 & 1 \mathrm{~g} & \text { SU } & -- & 1548 \\ 87.50 & 100 \mathrm{~g} & \text { CU } & 2.0 & 1550\end{array}$

$\begin{array}{rrlll}110.00 & 1 \mathrm{~L} & \text { FAR } & 1 & 1506 \\ 122.50 & 1 \mathrm{~g} & \text { SU } & 0.1 & 1544 \\ 131.25 & 10 \mathrm{~g} & \text { CU } & 0.1 & 1546\end{array}$

Bottles - Acid rinsed polyethylene.

166.25

166.25
153.75

123.75

111.25

157.50

RUR
FAR
RUR
FAR
SU

$\begin{array}{lr}0.02 & 862 \\ 0.02 & 861 \\ 0.4 & 863 \\ 0.4 & 864 \\ 0.1 & 1532\end{array}$

For samples requiring filtration and acidification, use 0.45 um filter and acidify to pH $<2$ using concentrated nitric acid (usually 3 mL of concentrated $\mathrm{HCl} / \mathrm{L}$ are sufficient).

Remark: 2 SPE code is the 2 standard deviation value reported for the corresponding parameter. 


\begin{tabular}{|c|c|c|c|c|c|c|c|c|}
\hline Schedule & $\begin{array}{l}\text { Lab } \\
\text { code }\end{array}$ & $\begin{array}{l}\text { WATSTORE } \\
\text { and Method } \\
\text { code }\end{array}$ & Parameter name and unit of measurement & $\begin{array}{c}\text { Price } \\
(\$)\end{array}$ & $\begin{array}{l}\text { Sample } \\
\text { volume }\end{array}$ & $\begin{array}{l}\text { Sample } \\
\text { desig- } \\
\text { nation }\end{array}$ & $\begin{array}{l}\text { Reporting } \\
\text { leve } 1\end{array}$ & $\begin{array}{r}2 \text { SPE } \\
\text { code }\end{array}$ \\
\hline
\end{tabular}

Radium and radon--Cont inued

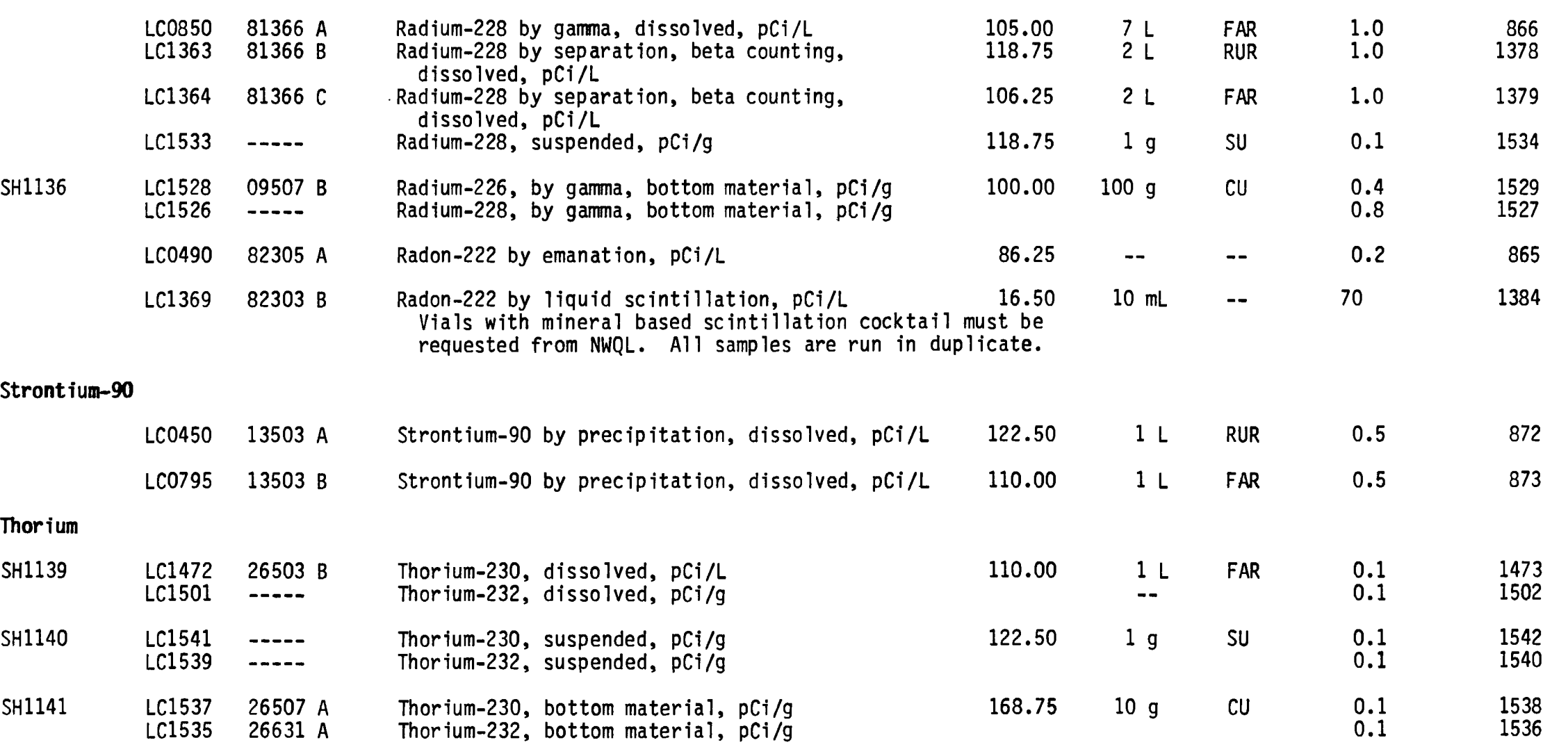

Bottles - Acid rinsed polyethylene.

For samples requiring filtration and acidification, use 0.45 um filter and acidify to $\mathrm{pH}<2$ using concentrated nitric acid (usually $3 \mathrm{~mL}$ of concentrated $\mathrm{HNO}_{3} / \mathrm{L}$ are sufficient).

Remark: 2 SPE code is the 2 standard deviation value reported for the corresponding parameter. 


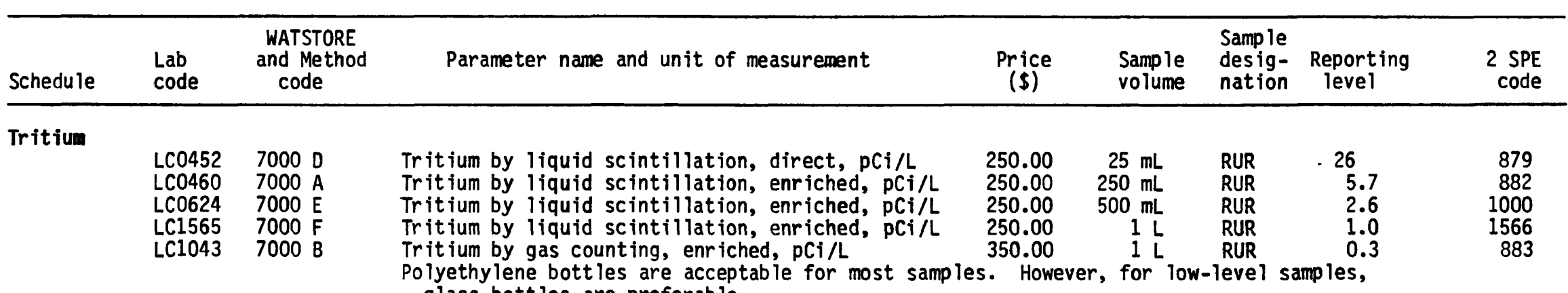

Uraniun

glass bottles are preferable.

\begin{tabular}{|c|c|c|c|c|c|c|c|c|}
\hline & $\begin{array}{l}\text { LC1365 } \\
\text { LC1004 } \\
\text { LC1006 } \\
\text { LC1388 }\end{array}$ & $\begin{array}{l}28011 \mathrm{~B} \\
22703 \mathrm{G} \\
22703 \mathrm{H} \\
22703 \mathrm{~F}\end{array}$ & $\begin{array}{l}\text { Uranium by fluorometric (total) ug/L } \\
\text { Uranium by fluorometric, dissolved, ug/L } \\
\text { Uranium by fluorometric, dissolved, ug/L } \\
\text { Uranium by laser-induced phosphorimetry, extracted, }\end{array}$ & $\begin{array}{l}37.50 \\
56.25 \\
43.75 \\
68.75\end{array}$ & 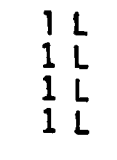 & $\begin{array}{l}\text { RAR } \\
\text { RUR } \\
\text { FAR } \\
\text { RUR }\end{array}$ & $\begin{array}{l}1.0 \\
1.0 \\
1.0 \\
0.01\end{array}$ & $\begin{array}{l}1447 \\
1005 \\
1007 \\
1392\end{array}$ \\
\hline & LC1386 & $22703 \mathrm{E}$ & $\begin{array}{l}\text { Uranium by laser-induced phosphorimetry, extracted } \\
\text { dissolved, ug/L }\end{array}$ & 56.25 & $1 \mathrm{~L}$ & FAR & 0.01 & 1390 \\
\hline & LC1387 & 227030 & Uranium by laser-induced phosphorimetry, direct, & 61.25 & $1 \mathrm{~L}$ & RUR & 0.4 & 1391 \\
\hline & LC1385 & $22703 \mathrm{C}$ & $\begin{array}{l}\text { Uranium by iaser-induced phosphorimetry, direct, } \\
\text { dissolved, ug/L }\end{array}$ & 48.75 & $1 \mathrm{~L}$ & FAR & 0.4 & 1389 \\
\hline SH1130 & $\begin{array}{l}\text { LC1366 } \\
\text { LC1367 } \\
\text { LC1368 }\end{array}$ & $\begin{array}{l}22610 \mathrm{~A} \\
22620 \mathrm{~A} \\
22603 \mathrm{~A}\end{array}$ & $\begin{array}{l}\text { Uranium-234 (by alpha spec) dissolved, } \mathrm{pCi} / \mathrm{L} \\
\text { Uranium-235 " " " " " } \\
\text { Uranium-238 " } \\
\text { Please note that these results are in } \mathrm{pCi} / \mathrm{L} \\
\mathrm{pCi} / \mathrm{L} \text {. }\end{array}$ & 80.50 & $1 \mathrm{~L}$ & FAR & $\begin{array}{l}0.1 \\
0.1 \\
0.1\end{array}$ & $\begin{array}{l}1381 \\
1382 \\
1383\end{array}$ \\
\hline SH1137 & $\begin{array}{l}\text { LC1474 } \\
\text { LC1476 } \\
\text { LC1507 }\end{array}$ & --- & $\begin{array}{l}\text { Uranium-234, suspended, } \mathrm{pCi} / \mathrm{g} \\
\text { Uran ium-235, suspended, } \mathrm{pCi} / \mathrm{g} \\
\text { Uranium-238, suspended, } \mathrm{pCi} / \mathrm{g}\end{array}$ & 128.75 & $1 \mathrm{~g}$ & SU & $\begin{array}{l}0.1 \\
0.1 \\
0.1\end{array}$ & $\begin{array}{l}1475 \\
1450 \\
1508\end{array}$ \\
\hline SH1138 & $\begin{array}{l}\text { LC1509 } \\
\text { LC1515 } \\
\text { LC1511 }\end{array}$ & $\begin{array}{l}28014 \text { A } \\
22612 \text { A } \\
28016 \text { A }\end{array}$ & $\begin{array}{l}\text { Uranium-234, by garma, bottom material, } \mathrm{pCi} / \mathrm{g} \\
\text { Uranium-235, by gamma, bottom material, } \mathrm{pCi} / \mathrm{g} \\
\text { Uranium-238, by gamma, bottom material, } \mathrm{pCi} / \mathrm{g}\end{array}$ & 168.75 & $100 \mathrm{~g}$ & CU & $\begin{array}{l}1.0 \\
1.0 \\
1.0\end{array}$ & $\begin{array}{l}1510 \\
1516 \\
1517\end{array}$ \\
\hline
\end{tabular}

Bottles - Acid rinsed polyethylene.

For samples requiring filtration and acidification, use 0.45 um filter and acidify to $\mathrm{pH}<2$ using concentrated nitric acid (usually $3 \mathrm{~mL}$ of concentrated $\mathrm{HNO}_{3} / \mathrm{L}$ are sufficient).

Remark: 2 SPE code is the 2 standard deviation value reported for the corresponding parameter. 
Table 4.2.--Stable Isotopes

$\stackrel{f}{\stackrel{i}{N}}$

\begin{tabular}{|c|c|c|c|c|c|c|}
\hline $\begin{array}{l}\text { Lab } \\
\text { code }\end{array}$ & $\begin{array}{l}\text { WATSTORE } \\
\text { and method } \\
\text { code }\end{array}$ & Parameter name and unit of measurement & $\begin{array}{c}\text { Price } \\
(\$)\end{array}$ & $\frac{\text { Sample } r}{\text { Preferred }}$ & $\frac{\text { requirements }}{\text { Absolute Minimum }}$ & Precision \\
\hline LC1137 & $82337 \mathrm{~A}$ & Oxygen-18/oxygen-16, carbonate rock, permil relative to SMOW* & 56.40 & $\begin{array}{l}1 \text { g pure } \\
\text { calcite }\end{array}$ & $\begin{array}{l}4 \text { mg pure } \\
\text { calc ite }\end{array}$ & $+/-0.2$ \\
\hline LC1243 & $99481 \mathrm{~A}$ & $\begin{array}{l}\text { Oxygen-18/0xyen-16, high purity } \mathrm{CO}_{2} \text {, aqueous, permil relative to SMOW } \\
\text { Use } 6 \text { or } 9 \mathrm{~mm} 0.0 \text {. pyrex tube }\end{array}$ & 19.20 & 100 u moles & 40 u moles & $+/-0.2$ \\
\hline LCO489 & 82085 A & $\begin{array}{l}\text { Oxygen-18/oxygen-16, aqueous, permil relative to SMOW } \\
\text { Add one } \mathrm{HgCl}_{2} \text { tablet, if possible. Do not add aqueous } \mathrm{HgCL}_{2} \text {. }\end{array}$ & 44.40 & $60 \mathrm{~mL}$ & mL (no headspace) & $+/-0.15$ \\
\hline LCO300 & $82082 \mathrm{~A}$ & $\begin{array}{l}\text { Deuter ium/protium, aqueous, permil relative SMOW } \\
\text { Add one } \mathrm{HgCl}_{2} \text { tablet, if possible. Do not add aqueous } \mathrm{HgCL}_{2} \text {. }\end{array}$ & 81.60 & $60 \mathrm{~mL}$ & m1 (no headspace) & $+1-1.5$ \\
\hline SH1142 & $\begin{array}{l}82085 \text { A } \\
82082 \mathrm{~A}\end{array}$ & $\begin{array}{l}\text { Oxygen and hydrogen isotope ratios } \\
\text { 0xygen-18/oxygen-16, aqueous, permil relative to SMOW } \\
\text { Deuterium/protium, aqueous, permil relative to SMOW } \\
\text { Add one } \mathrm{HgCL}_{2} \text { tablet, possible. Do not add aqueous } \mathrm{HgCl}_{2} \text {. }\end{array}$ & 126.00 & $60 \mathrm{~mL}$ & & \\
\hline LC1204 & $-\ldots-$ & Nitrogen-15/nitrogen-14, solid organic, permil relative to air & 126.00 & $1 \mathrm{~g} \mathrm{~N}$ & $1 \mathrm{mg} \mathrm{N}$ & $+/-0.2$ \\
\hline LCo995 & $82084 \mathrm{~A}$ & $\begin{array}{l}\text { Nitrogen- } 15 / n \text { itrogen }-14 \text {, aqueous, permil relative to air } \\
\text { Filter through } 0.45 \text { um filter. } \\
\text { Preserve with bactericide (mercuric chloride). } \\
\text { Keep cool - Do not freeze. } \\
\text { Please provide concentration if possible. }\end{array}$ & 240.00 & $\begin{array}{l}>5 \mathrm{mg} \mathrm{N} \text { in } \\
\text { a } 1-\mathrm{L} \text { bottle }\end{array}$ & $\begin{array}{l}0.1 \mathrm{mg} N / L \text { in } \\
\max \text { vol of } 2 \mathrm{~L}\end{array}$ & $+/-0.2$ \\
\hline LC1138 & $82336 \mathrm{~A}$ & $\begin{array}{l}\text { Sulfur-34/sulfur-32, solid samples, permil relative to CDT } \\
\text { Organic sulfur, sulf ide rocks, total sulfur }\end{array}$ & 110.00 & $1 \mathrm{~g} \mathrm{~S}$ & $0.7 \mathrm{mg} \mathrm{s}$ & $+/-0.3$ \\
\hline LC0535 & ----- & $\begin{array}{l}\text { Sulfur-34/sulfur-32, aqueous (sulfide precipitate), permil } \\
\text { relative to CDT } \\
\text { Filter through } 0.45 \text { um filter. } \\
\text { Preserve with bactericide (mercuric chloride). } \\
\text { Please provide concentration if available. }\end{array}$ & 110.00 & $\begin{array}{l}>10 \mathrm{mg} S \text { in } \\
\text { a } 1-L \text { bottle }\end{array}$ & $\begin{array}{l}0.5 \mathrm{mg} S / L \text { in } \\
\max \text { vol of } 2 L\end{array}$ & $+/-0.3$ \\
\hline
\end{tabular}

Bottles - Gastight, inert polyethylene or glass with leak-free teflon or polyseal caps. Tape caps. For solids - any spill-proof container.

$\vec{*}$ *If requested in conjunction with LC 1135 , only one sample is required. Separate analyses can be performed on both the calcite and dolomite fractions of a carbonate rock (please provide percentages of each). 


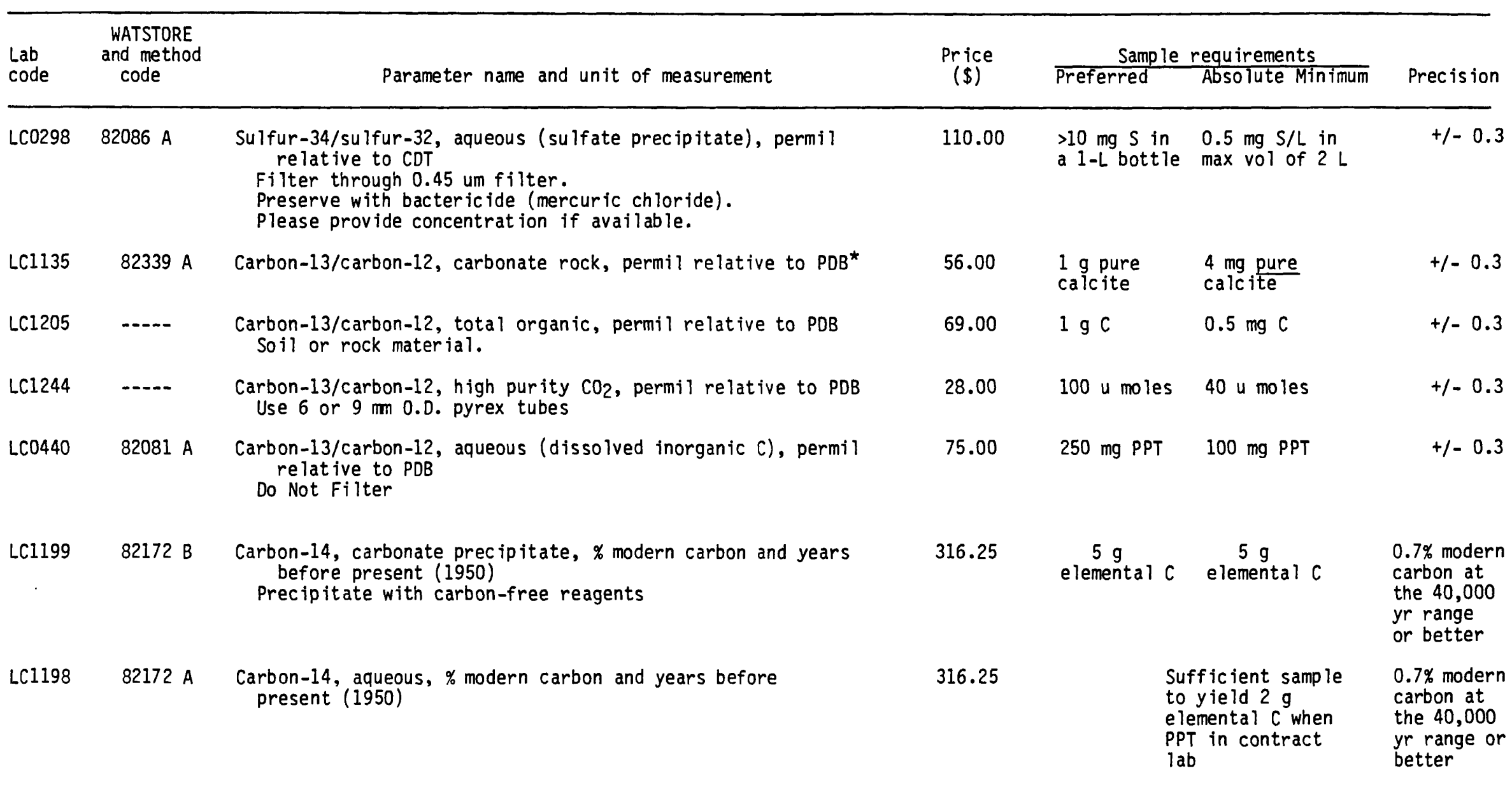

LC0640 99454 A Carbon-14, percent error, given with both LC 1199 and LC $1198 \quad$ No cost 


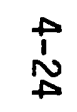

్ㅗㅀ 


\begin{tabular}{llll}
\hline $\begin{array}{l}\text { Lab code } \\
\text { or } \\
\text { schedule }\end{array}$ & Class & $\begin{array}{c}\text { WATSTORE \& } \\
\text { method } \\
\text { code }\end{array}$ & Parameter name and unit of measurement \\
\hline
\end{tabular}

\section{Biological compounds}

Periphyton

\begin{tabular}{|c|c|c|c|c|c|c|}
\hline \multirow[t]{2}{*}{ SH1507 } & Limited & Chlorophy11, periphyton & 32.37 & -- & CHE & .1 \\
\hline & & $\begin{array}{l}70957 \text { A Chlorophyll-a }\left(\mathrm{mg} / \mathrm{m}^{2}\right) \\
70958 \text { A Chlorophy11-b }\left(\mathrm{mg} / \mathrm{m}^{2}\right)\end{array}$ & & & & \\
\hline \multirow[t]{2}{*}{ SH0671 } & Limited & Periphyton, biomass & 28.58 & -- & CHE & .001 \\
\hline & & $\begin{array}{l}00573 \text { A Periphyton, dry weight }\left(\mathrm{g} / \mathrm{m}^{2}\right) \\
00572 \text { A Periphyton, ash weight }\left(\mathrm{g} / \mathrm{m}^{2}\right)\end{array}$ & & & & \\
\hline \multicolumn{7}{|c|}{ Phytoplankton } \\
\hline \multirow[t]{2}{*}{ SH1508 } & Limited & Chlorophyl1, phytoplankton & 32.37 & -- & $\mathrm{CHY}$ & .1 \\
\hline & & $\begin{array}{l}70953 \text { A Chlorophyl1-a, phytoplankton (ug/L) } \\
70954 \text { A Chlorophyl1-b, phytoplankton (ug/L) }\end{array}$ & & & & \\
\hline \multirow[t]{2}{*}{ SH0666 } & Limited & Phytoplankton, biomass & 28.58 & -- & CHY & 1 \\
\hline & & $\begin{array}{l}81354 \text { A Phytoplankton, dry weight (mg/L) } \\
81353 \text { A Phytoplankton, ash weight (mg/L) }\end{array}$ & & & & \\
\hline
\end{tabular}




\begin{tabular}{|c|c|c|c|c|c|c|c|c|}
\hline $\begin{array}{l}\text { Lab code } \\
\text { or } \\
\text { schedule }\end{array}$ & Class & $\begin{array}{l}\text { WATSTORE \& } \\
\text { method } \\
\text { code }\end{array}$ & Parameter name and unit of measurement & $\begin{array}{l}\text { Price } \\
(\$)\end{array}$ & $\begin{array}{l}\text { Sample } \\
\text { volume }\end{array}$ & $\begin{array}{l}\text { Sample } \\
\text { desig- } \\
\text { nation }\end{array}$ & $\begin{array}{l}\text { Reporting } \\
\text { leve } 1\end{array}$ & Remarks \\
\hline
\end{tabular}

\section{Gross measures}

LC0306 Regular 00691 A Carbon, inorganic, dissolved (mg/L as C)

LC0113 Regular 00681 A Carbon, organic, dissolved (mg/L as C)

LC0305 Regular 00689 A Carbon, organic, suspended (mg/L as C)

LCO019 Regular 00685 A Carbon, inorganic, total (mg/L as C)

LCO114 Regular 00680 A Carbon, organic, total (mg/L as C)

LC0503 Regular 00686 C Carbon, inorganic, total in bottom material, dry wt. (g/kg as C)

LC0133 Regular 00693 A Carbon, inorganic plus organic, total in bottom material, dry wt. ( $\mathrm{g} / \mathrm{kg}$ as $\mathrm{C}$ )

LC0096 Regular 38260 A Methylene blue active substances, total recoverable (mg/L as MBAS)

LC0127 Regular $00556 \mathrm{~A} 0 \mathrm{il}$ and grease, total recoverable (mg/L)

LC0531 Regular $00557 \mathrm{~A} \mathrm{Oil}$ and grease, rec from bottom material, dry wt. $(\mathrm{mg} / \mathrm{kg})$

LC0052 Regular 32730 A Phenols, total recoverable (ug/L as phenol)

LC0138 Regular $32240 \mathrm{~A}$ Tannin and lignin, total recoverable (mg/L as tannic acid)

\section{Industrial compounds}

\section{Methylene chloride-extractable compounds}

\section{SH1383 Limited \\ GC/MS analys is of semi-volatile priority pollutants, base/neutral plus acid-extractable, total recoverable, total recoverable from water and suspended sediment. (ug/L)}

34452 A 4-Chloro-3-methylphenol (ug/L)

34586 A 2-Chlorophenol (ug/L)

34601 A 2,4-Dichlorophenol (ug/L)

34606 A 2,4-Dimethylpheno1 (ug/L)

34616 A 2,4-Dinitrophenol (ug/L)

34657 A 4,6-Dinitro-2-methylphenol (ug/L)

34591 A 2-Nitrophenol (ug/L)

34646 A 4-Nitrophenol (ug/L)

39032 A Pentachlorophenol (ug/L)

34694 A Phenol (ug/L)

34621 A 2,4,6-Trichlorophenol (ug/L)

$\begin{array}{lllc}22.08 & 100 \mathrm{~mL} & \text { LCO306 } & .1 \\ 22.08 & 100 \mathrm{~mL} & \text { LCO113 } & .1 \\ 22.08 & -- & \text { LCO305 } & .1 \\ 22.08 & 100 \mathrm{~mL} & \text { LCO019 } & .1 \\ 22.08 & 100 \mathrm{~mL} & \text { LCO114 } & .1 \\ 38.06 & 10 \mathrm{~g} & \text { CC } & .1 \\ 38.06 & 10 \mathrm{~g} & \text { CC } & .1 \\ 27.83 & 250 \mathrm{~mL} & \text { RCB } & .01 \\ 39.33 & 1 \mathrm{~L} & \text { LCO127 } & 1 \\ 55.78 & 10 \mathrm{~g} & \text { CC } & 1000 \\ 33.00 & 1 \mathrm{~L} & \text { LCO052 } & 1 \\ 26.00 & 100 \mathrm{~mL} & \text { RCB } & .1\end{array}$

$405.001 \mathrm{~L} \quad$ GCC 


\begin{tabular}{|c|c|c|c|c|c|c|c|c|}
\hline $\begin{array}{l}\text { Lab code } \\
\text { or } \\
\text { schedule }\end{array}$ & Class & $\begin{array}{l}\text { WATSTORE \& } \\
\text { method } \\
\text { code }\end{array}$ & Parameter name and unit of measurement & $\begin{array}{l}\text { Price } \\
(\$)\end{array}$ & $\begin{array}{l}\text { Sample } \\
\text { volume }\end{array}$ & $\begin{array}{l}\text { Sample } \\
\text { desig- } \\
\text { nation }\end{array}$ & $\begin{array}{l}\text { Reporting } \\
\text { leve } 1\end{array}$ & Remarks \\
\hline
\end{tabular}

\section{Industrial compounds--Continued}

Methylene chloride-extractable compounds--Continued

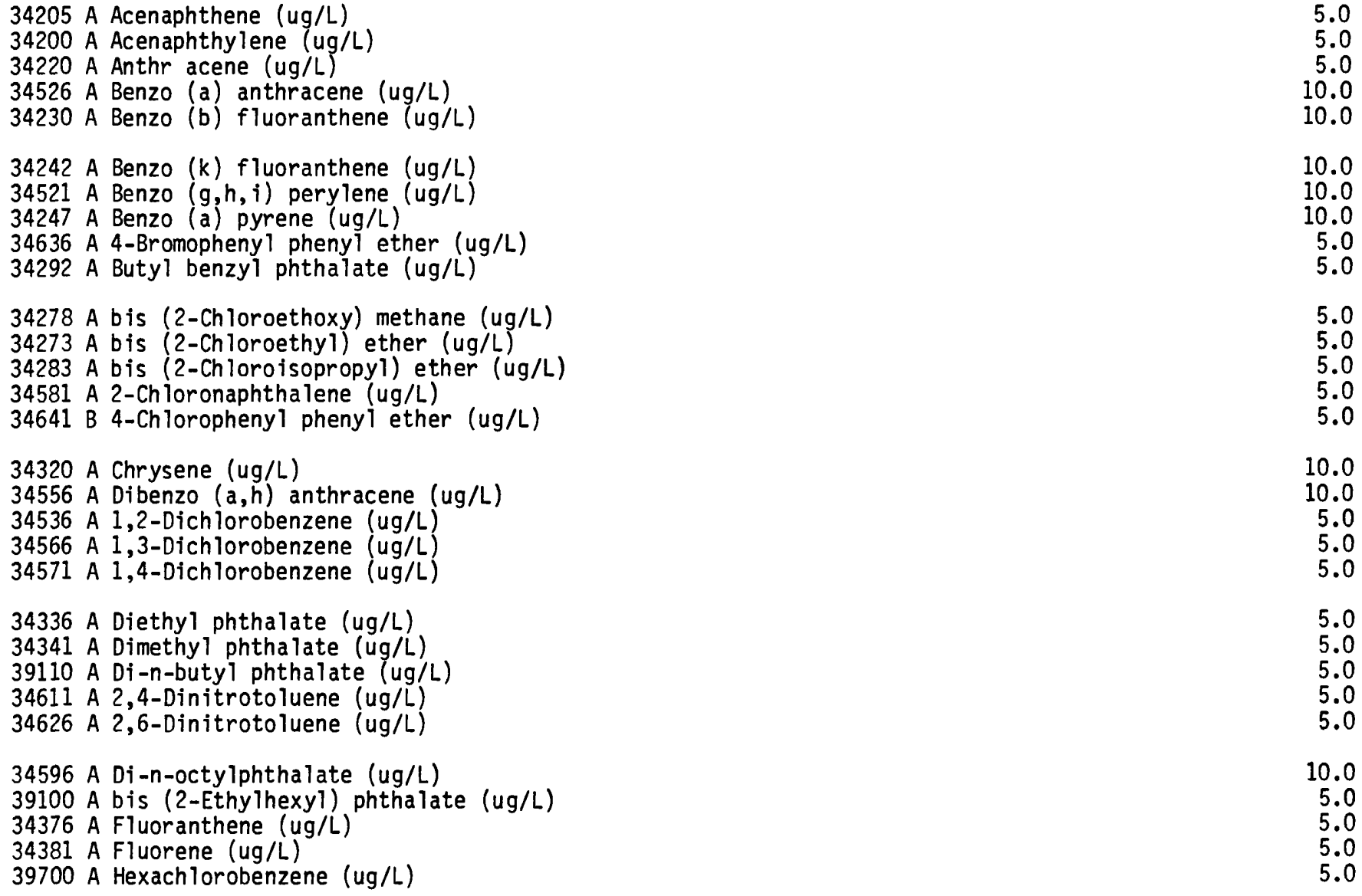




\begin{tabular}{|c|c|c|c|c|c|c|c|c|}
\hline $\begin{array}{l}\text { Lab code } \\
\text { or } \\
\text { schedule }\end{array}$ & Class & $\begin{array}{l}\text { WATSTORE \& } \\
\text { method } \\
\text { code }\end{array}$ & Parameter name and unit of measurement & $\begin{array}{l}\text { Price } \\
(\$)\end{array}$ & $\begin{array}{l}\text { Sample } \\
\text { volume }\end{array}$ & $\begin{array}{l}\text { Sample } \\
\text { desig- } \\
\text { nation }\end{array}$ & $\begin{array}{l}\text { Reporting } \\
\text { level }\end{array}$ & Remarks \\
\hline
\end{tabular}

\section{Industrial compounds--Continued}

Methylene chloride-extractable compounds--Continued

SH1383

39702 A Hexachlorobutadiene (ug/L)

34386 A Hexachlorocyclopentadiene (ug/L)

34396 A Hexachloroethane (ug/L)

34403 A Indeno $(1,2,3-c d)$ pyrene (ug/L)

34408 A Isophorone (ug/L)

34696 A Naphthalene (ug/L)

34447 A Nitrobenzene (ug/L)

34438 A n-Nitrosodimethylamine (ug/L)

34428 A $n$-Nitrosodi-n-propylamine (ug/L)

34461 A Phenanthrene (ug/L)

34469 A Pyrene (ug/L)

34551 A 1,2,4-Trichiorobenzene (ug/L)
34433 A $n$-Nitrosodiphenylamine (ug/L)

5.0

5.0

5.0

10.0
5.0

5.0

5.0

5.0

5.0

5.0

5.0

SH1381 Limited

Organic compounds, methylene chloride-extractable, GC/FID scan, total recoverable from water and water-suspended sediment. Chromatogram and Data Summary are mailed to requestor. (ug/L)

SH1382 Limited

Organic compounds, methylene chloride-extractable, GC/FID scan, recoverable from bottom material. Chromatogram and Data Summary are mailed to requestor. ( $\mathrm{ug} / \mathrm{kg}$ )
$114.00 \quad 1 \mathrm{~L} \quad$ GCC $\quad .1-100$

$152.00200 \mathrm{~g} \quad \mathrm{BGC} \quad 4.0-4,000$ 


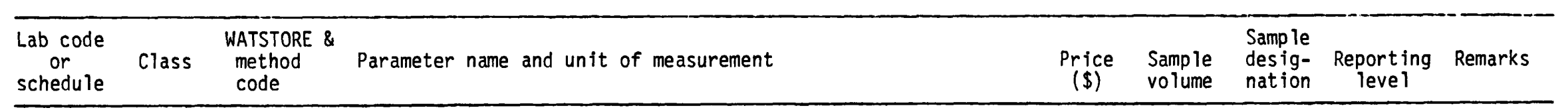

\section{Industrial compounds--Continued}

Methylene chloride-extractable compounds--Cont inued

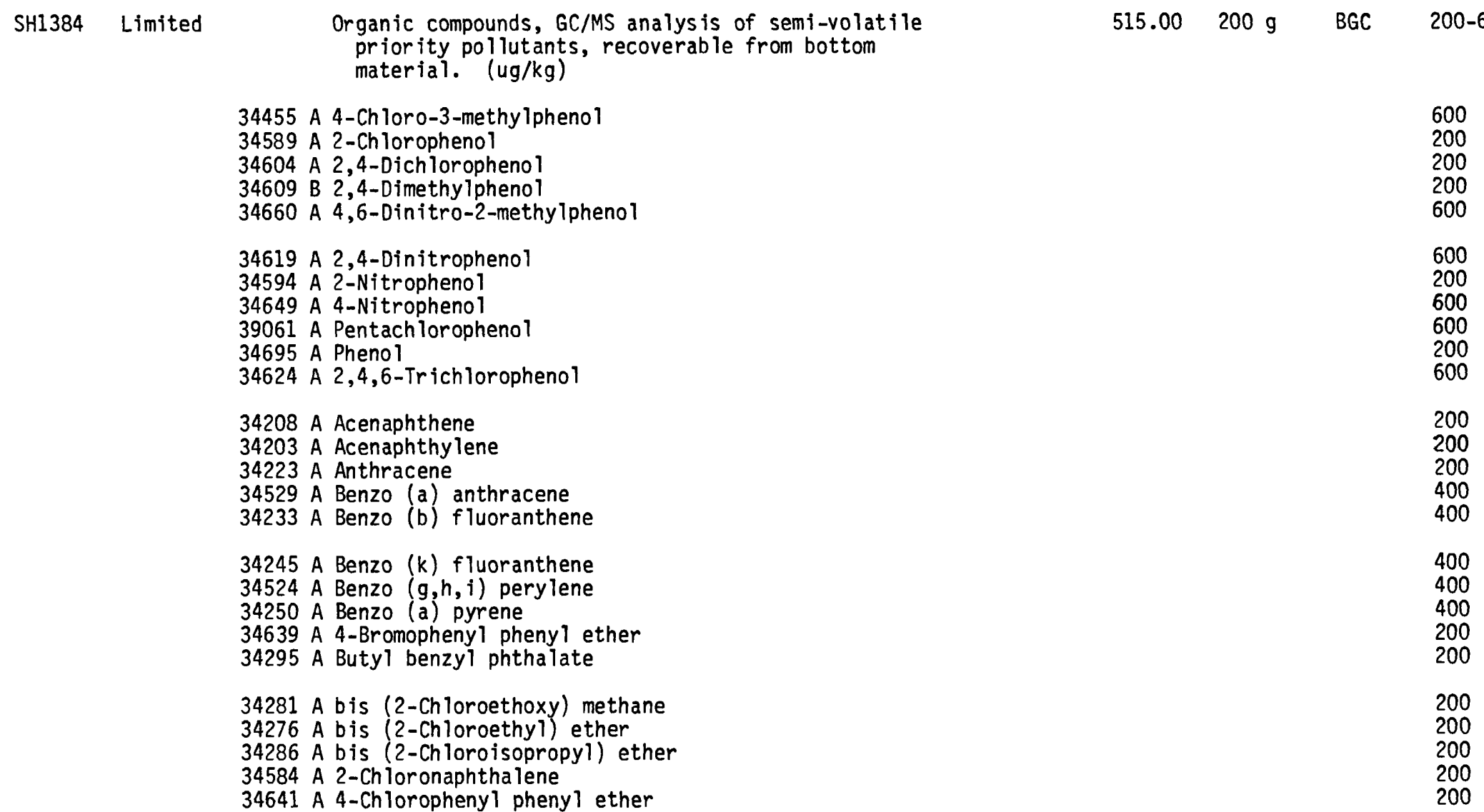


Table 4.3.--Organic Analyses--Continued

\begin{tabular}{|c|c|c|c|c|c|c|c|c|}
\hline $\begin{array}{l}\text { Lab code } \\
\text { or } \\
\text { schedule }\end{array}$ & Class & $\begin{array}{l}\text { WATSTORE \& } \\
\text { method } \\
\text { code }\end{array}$ & Parameter name and unit of measurement & $\begin{array}{c}\operatorname{Price} \\
(\$)\end{array}$ & $\begin{array}{l}\text { Sample } \\
\text { volume }\end{array}$ & $\begin{array}{l}\text { Sample } \\
\text { desig- } \\
\text { nation }\end{array}$ & $\begin{array}{l}\text { Reporting } \\
\text { level }\end{array}$ & Remarks \\
\hline
\end{tabular}

Industrial compounds--Continued

Methylene chloride-extractable compounds--Continued

SH1384

34323 A Chrysene 400

34559 A Dibenzo (a,h) anthracene 400

34539 A 1,2-Dichlorobenzene 200

34569 A 1,3-Dichlorobenzene 200

34574 A 1,4-Dichlorobenzene 200

34339 A Diethyl phthalate 200

34344 A Dimethyl phthalate 200

39112 A Di-n-butyl phthalate 200

34614 A 2,4-Dinitrotoluene 200

34629 A 2,6-Dinitrotoluene

34599 A Di-n-octylphthalate 400

39102 A bis (2-Ethylhexyl) phthalate 200

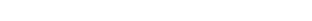

39701 A Hexachlorobenzene 200

39705 A Hexachlorobutadiene 200

39389 A Hexachlorocyclopentadiene 200

200

34406 A Indeno $(1,2,3-c d)$ pyrene 400

34411 A Isophorone 200

34445 A Naphthalene 200

34450 A Nitrobenzene 200

34441 A n-Nitrosodimethyla

200

34436 A n-Nitrosodiphenylamine 200

34464 A Phenanthrene 200

34472 A Pyrene 200 


\begin{tabular}{|c|c|c|c|c|c|c|c|c|}
\hline $\begin{array}{l}\text { Lab code } \\
\text { or } \\
\text { schedule }\end{array}$ & Class & $\begin{array}{l}\text { WATSTORE \& } \\
\text { method } \\
\text { code }\end{array}$ & Parameter name and unit of measurement & $\begin{array}{l}\text { Price } \\
(\$)\end{array}$ & $\begin{array}{l}\text { Sample } \\
\text { volume }\end{array}$ & $\begin{array}{l}\text { Sample } \\
\text { desig- } \\
\text { nation }\end{array}$ & $\begin{array}{c}\text { Reporting } \\
\text { leve } 1\end{array}$ & Remarks \\
\hline
\end{tabular}

Industrial compounds--Continued

Methylene chloride-extractable compounds--Continued

SH1385 Limited

SH1386 Limited

\section{Munition products}

Organic compounds, base/neutral plus acid-extractable, semi-quantitative GC/MS analys is of semi-volatile, methylene chloride-extractable organic compounds, total

recoverable from water and water-suspended sediment mixtures. Includes specific analys is for compounds

listed in SHI383 and tentative identification

of all other compounds possible with quantitation

relative to the internal standard. Letter report sent

to requestor. (ug/L)

Organic compounds, recoverable from bottom material. Semiquantitative GC/MS analys is of semi-volatile, methylene chloride extractable organic compounds. Includes spec if ic analys is for compounds listed in SH1384 and tentative identification of all other compounds possible with quantitation relative to the internal standard. Letter report sent to requestor. (ug/ $\mathrm{kg}$ )
Munition products, with picric acid, total recoverable
584.00

$1 L$

GCC

$5-30$

$658.00 \quad 100 \mathrm{~g} \quad$ BGC $\quad 200-600$

SH1300 Limited

82340 A Picric acid (ug/L)

81364 B RDX (ug/L)

$81360 \mathrm{C}$ TNT (ug/L)
$448.00 \quad 800 \mathrm{~mL} \quad$ GCC

(Remarks: $D$, this schedule is available only through a contract laboratory.) 


\begin{tabular}{|c|c|c|c|c|c|c|c|c|}
\hline $\begin{array}{l}\text { Lab code } \\
\text { or } \\
\text { schedule }\end{array}$ & Class & $\begin{array}{l}\text { WATSTORE \& } \\
\text { method } \\
\text { code }\end{array}$ & Parameter name and unit of measurement & $\begin{array}{c}\text { Price } \\
(\$)\end{array}$ & $\begin{array}{l}\text { Sample } \\
\text { volume }\end{array}$ & $\begin{array}{l}\text { Sample } \\
\text { desig- } \\
\text { nation }\end{array}$ & $\begin{array}{l}\text { Reporting } \\
\text { level }\end{array}$ & Remarks \\
\hline
\end{tabular}

\section{Industrial compounds--Continued}

Polychlorinated biphenyls

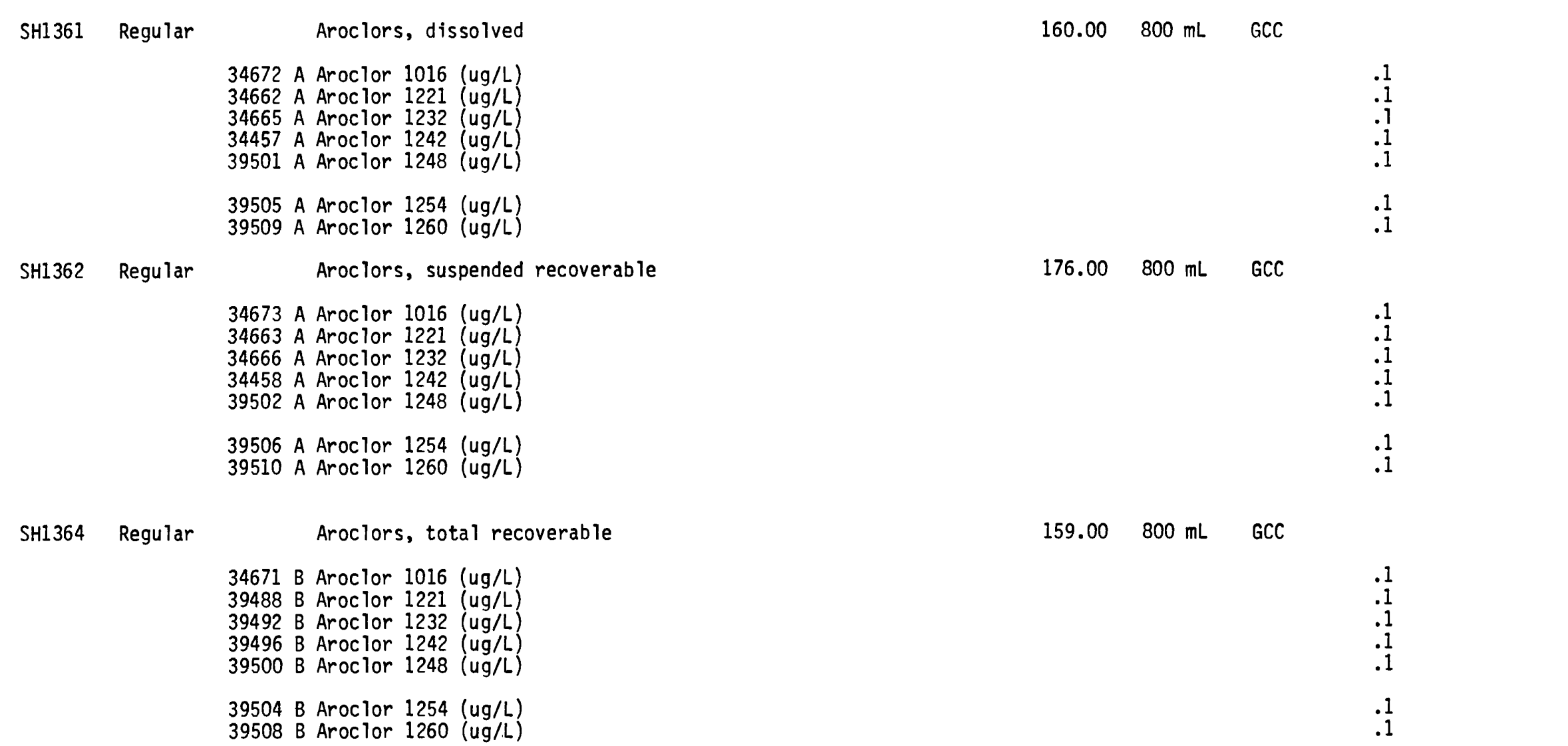




\begin{tabular}{|c|c|c|c|c|c|c|c|c|}
\hline $\begin{array}{l}\text { Lab code } \\
\text { or } \\
\text { schedule }\end{array}$ & Class & $\begin{array}{l}\text { WATSTORE \& } \\
\text { method } \\
\text { code }\end{array}$ & Parameter name and unit of measurement & $\begin{array}{c}\text { Price } \\
(\$)\end{array}$ & $\begin{array}{l}\text { Sample } \\
\text { volume }\end{array}$ & $\begin{array}{l}\text { Sample } \\
\text { desig- } \\
\text { nation }\end{array}$ & $\begin{array}{l}\text { Reporting } \\
\text { level }\end{array}$ & Remarks \\
\hline
\end{tabular}

Industrial compounds--Continued

Polychlorinated biphenyls--Continued

$\begin{array}{ccc}\text { SH1397 Regular } & \text { Aroclors, recoverable from bottom material, dry wt. } & 343.00 \\ & & 200 \mathrm{~g} \\ & 39514 \text { A Aroclor } 1016(\mathrm{ug} / \mathrm{kg}) & \text { BGC } \\ 39491 \text { A Aroclor } 1221(\mathrm{ug} / \mathrm{kg}) & 1.0 \\ 39495 \text { A Aroclor } 1232(\mathrm{ug} / \mathrm{kg}) & 1.0 \\ 39499 \text { A Aroclor } 1242(\mathrm{ug} / \mathrm{kg}) & 1.0 \\ 39503 \text { A Aroclor } 1248(\mathrm{ug} / \mathrm{kg}) & 1.0 \\ 39507 \text { A Aroclor } 1254(\mathrm{ug} / \mathrm{kg}) & 1.0 \\ 39511 \text { A Aroclor } 1260(\mathrm{ug} / \mathrm{kg}) & 1.0\end{array}$

Reaeration

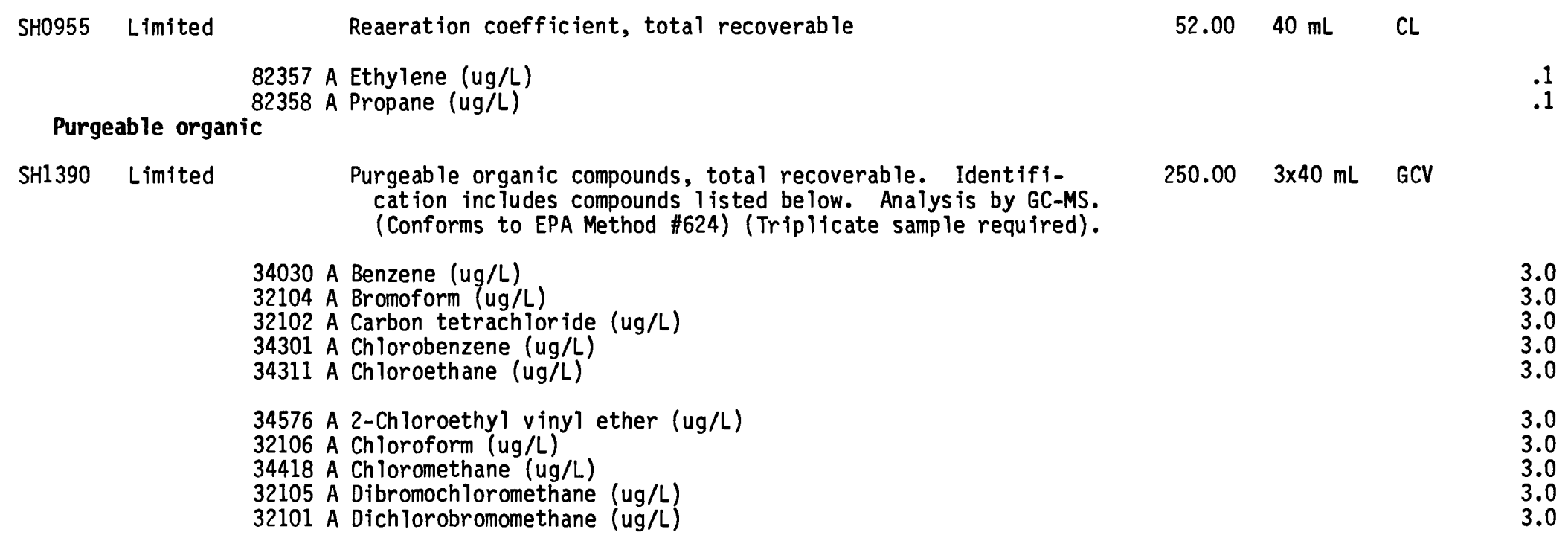

(Schedule continued on the next page)

(Remarks: C, analys is performed by 0cala Laboratory, contact Ocala for all arrangements.) 


\begin{tabular}{|c|c|c|c|c|c|c|c|c|}
\hline $\begin{array}{l}\text { Lab code } \\
\text { or } \\
\text { schedule }\end{array}$ & Class & $\begin{array}{l}\text { WATSTORE \& } \\
\text { method } \\
\text { code }\end{array}$ & Parameter name and unit of measurement & $\begin{array}{l}\text { Price } \\
(\$)\end{array}$ & $\begin{array}{l}\text { Sample } \\
\text { volume }\end{array}$ & $\begin{array}{l}\text { Sample } \\
\text { desig- } \\
\text { nation }\end{array}$ & $\begin{array}{c}\text { Reporting } \\
\text { level }\end{array}$ & Remarks \\
\hline
\end{tabular}

\section{Industrial compounds--Continued}

\section{Purgeable organic--Cont inued}

SH1390

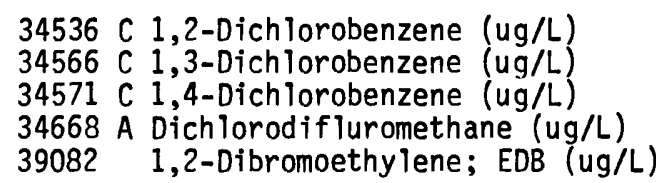

34496 A 1,1-Dichloroethane (ug/L)

32103 A 1,2-Dichloroethane (ug/L)

34501 A 1,1-Dichloroethylene (ug/L)

34546 A 1,2-trans-Dichloroethylene (ug/L)

34541 A 1,2 -Dichloropropane (ug/L)

$\begin{array}{rr} & 3.0 \\ & 3.0 \\ & 3.0 \\ 3.0 \\ 3.0 \\ \\ \\ \\ \\ \\ \\ \\ \\ \\ \\ \\ \\ \\ \\ \\ \\ \\ \\ \\ \\ \\ \\ \\ \\ \end{array}$

34704 A Cis-1,3-Dichloropropene

34699 A Trans-1,3-Dichloropropene

34561 A 1,3-Dichloropropene (ug/L)

34371 A Ethylbenzene (ug/L)

34413 A Methyl bromide (ug/L)

3.0

77128 A Styrene (ug/L)

34423 A Methylene chloride (ug/L)

34516 A 1,1,2,2-Tetrach loroethane (ug/L)

3.0

34475 A Tetrachloroethylene; PCE (ug/L)

34506 A 1,1,1-Trichloroethane (ug/L)

34511 A 1,1,2-Trichloroethane (ug/L)

39180 A Trichloroethylene; TCE (ug/L)

3.0

39175 A Vinyl chloride (ug/L)

81551 A xylenes, mixed (ug/L)

SH1391 Limited

GC/MS analys is of purgeable organic compounds. Conforms

to EPA Method \#524. Includes all compounds listed in

SH 1390. Triplicate sample required. (ug/L)

SH1392 Limited
GC/MS analys is of purgeable organ ic compounds. Conforms to EPA Method \#524. Includes all compounds listed in SH 1390 and tentative identification of all other compounds. Quantitation relative to internal standard. Triplicate sample required. (ug/L) 


\begin{tabular}{|c|c|c|c|c|c|c|c|c|}
\hline $\begin{array}{l}\text { Lab code } \\
\text { or } \\
\text { schedu te }\end{array}$ & Class & $\begin{array}{l}\text { WATSTORE \& } \\
\text { method } \\
\text { code }\end{array}$ & Parameter name and unit of measurement & $\begin{array}{l}\text { Price } \\
(\$)\end{array}$ & $\begin{array}{l}\text { Sample } \\
\text { volume }\end{array}$ & $\begin{array}{l}\text { Sample } \\
\text { desig- } \\
\text { nation }\end{array}$ & $\begin{array}{l}\text { Reporting } \\
\text { leve } 1\end{array}$ & Remarks \\
\hline
\end{tabular}

\section{Pesticides}

Carbamate insecticides

SH1359 Limited Carbamate insecticides, total recoverable

-...- C Aldicarb (ug/L)

-.- C Aldicarb sulfoxide (ug/L)

-..- C Aldicarb sulfone (ug/L)

-..- C Carbofuran (ug/L)

-... A 3-Hydroxycarbofuran (ug/L)

39051 A Methomy1 (ug/L)

-..- A 1-Naphthol (ug/L)

-...- C Oxamyl (ug/L)

39052 A Propham (ug/L)

39750 A Carbaryl (ug/L)

\section{Chlorophenoxy acid herbicides}

SH1301 Regular

Chlorophenoxy acid herbicides, dissolved

39732 A 2,4-D (ug/L)

82356 A 2,4-DP (ug/L)

39762 A Silvex (ug/L)

39742 A 2,4,5-T (ug/L)

SH1302 Regular Chlorophenoxy acid herbicides, suspended recoverable

39733 A 2,4-D (ug/L)

34608 A 2,4-DP (ug/L)

39763 A Silvex (ug/L)

39743 A $2,4,5-T(\mathrm{ug} / \mathrm{L})$

SH1304 Regular Chlorophenoxy acid herbicides, total recoverable

39730 B 2,4-D (ug/L)

82183 A 2,4-DP $(\mathrm{ug} / \mathrm{L})$

39760 B Silvex (ug/L)

39740 B 2,4,5-T (ug/L)
$201.00 \quad 800 \mathrm{~mL} \quad$ GCC

0.5

0.5

0.5

0.5

0.5

0.5

0.5
0.5

0.5

$268.00 \quad 800 \mathrm{~mL} \quad$ GCC

.01

.01

$300.00 \quad 800 \mathrm{~mL} \quad$ GCC

.01

.01

.01

$251.00 \quad 800 \mathrm{~mL} \quad$ GCC 


\begin{tabular}{|c|c|c|c|c|c|c|c|}
\hline $\begin{array}{l}\text { Lab code } \\
\text { or } \\
\text { schedule }\end{array}$ & Class $\begin{array}{l}\text { WATSTORE \& } \\
\text { method } \\
\text { code }\end{array}$ & Parameter name and unit of measurement & $\begin{array}{l}\text { Price } \\
(\$)\end{array}$ & $\begin{array}{l}\text { Sample } \\
\text { volume }\end{array}$ & $\begin{array}{l}\text { Sample } \\
\text { desig- } \\
\text { nation }\end{array}$ & $\begin{array}{l}\text { Reporting } \\
\text { level }\end{array}$ & Remarks \\
\hline
\end{tabular}

\section{Pesticides--Continued}

\section{SH0079 Limited}

Chlorophenoxy acid herbicides with dicamba and picloram, total recoverable

$273.00 \quad 800 \mathrm{~mL} \quad$ GCC

$$
\begin{aligned}
& 39730 \text { B } 2,4-D(u g / L) \\
& 82052 \text { A Dicamba (ug/L) } \\
& 82183 \text { A 2,4-DP (ug/L) } \\
& 39720 \text { A Picloram (ug/L) } \\
& 39760 \text { B SiTvex (ug/L) } \\
& 39740 \text { B } 2,4,5-T(u g / L)
\end{aligned}
$$

SH1305 Regular

$$
\text { Chlorophenoxy }
$$$$
\text { dry wt. }
$$

$$
\begin{aligned}
& 39731 \text { A } 2,4-D(u g / k g) \\
& 34609 \text { A } 2,4-D P(u g / k g) \\
& 39761 \text { A Si Tvex (ug/kg) } \\
& 39741 \text { A } 2,4,5-T(u g / k g)
\end{aligned}
$$

SH0080 Limited

Chlorophenoxy acid herbicides with dicamba and picloram, recoverable from bottom material, dry wt.

39731 A 2,4-D (ug/ $/ \mathrm{kg})$

38931 A Dicamba (ug/kg)

34609 A 2,4-DP (ug/kg)

38930 A Picloram (ug/kg)

39761 A Silvex (ug/kg)

39741 A 2,4,5-T (ug/kg)

Organochlorine compounds

SH1321 Regular Organochlorine insecticides with gross PCB, dissolved

39331 A Aldrin (ug/L)

39352 A Chiordane (ug/L)

39361 A DDD (ug/L)

39366 A DDE (ug/L)

39371 A DDT $(u g / L)$
.01

.01

.01

.01

.01

$200 \mathrm{~g} \quad \mathrm{BGC}$

$$
\begin{aligned}
& .1 \\
& .1 \\
& .1 \\
& .1
\end{aligned}
$$

$438.00 \quad 200 \mathrm{~g} \quad$ BGC

$$
\begin{aligned}
& .1 \\
& .1 \\
& .1 \\
& .1 \\
& .1 \\
& .1
\end{aligned}
$$

$160.00 \quad 800 \mathrm{~mL} \quad$ GCC 


\begin{tabular}{|c|c|c|c|c|c|c|c|}
\hline $\begin{array}{l}\text { Lab code } \\
\text { or } \\
\text { schedule }\end{array}$ & Class $\begin{array}{l}\text { WATSTORE \& } \\
\text { method } \\
\text { code }\end{array}$ & Parameter name and unit of measurement & $\begin{array}{c}\text { Price } \\
(\$)\end{array}$ & $\begin{array}{l}\text { Sample } \\
\text { volume }\end{array}$ & $\begin{array}{l}\text { Sample } \\
\text { desig- } \\
\text { nation }\end{array}$ & $\begin{array}{c}\text { Reporting } \\
\text { level }\end{array}$ & Remarks \\
\hline
\end{tabular}

\section{Pesticides--Continued}

Organochlorine compounds--Cont inued

SH1321

SH1322 Regular
39381 A Dieldrin (ug/L)

82354 A Endosulfan (ug/L)

39391 A Endrin (ug/L)

39517 A Gross polychlorinated biphenyls (ug/L as PCB)

82360 A Gross polychlorinated naphthalenes (ug/L as PCN)

39411 A Heptachlor (ug/L)

39421 A Heptachlor epoxide (ug/L)

39341 A Lindane (ug/L)

82350 A Methoxychlor (ug/L)

39756 A Mirex (ug/L)

82348 A Perthane (ug/L)

39401 A Toxaphene $(\mathrm{ug} / \mathrm{L})$

(\$) volume nation
Organochlorine insecticides with gross $\mathrm{PCB}$ and gross $\mathrm{PCN}$, suspended recoverable.

39332 A Aldrin (ug/L)

39353 A Chlordane (ug/L)

39362 A DDD (ug/L)

39367 A DDE (ug/L

39372 A DDT (ug/L)

39382 A Dieldrin (ug/L)

82355 A Endosulfan (ug/L

39392 A Endrin (ug/L)

39518 A Gross polychlorinated biphenyls (ug/L as PCB)

82361 A Gross polychlorinated naphthalenes (ug/L as PCN)

39412 A Heptachlor (ug/L)

39422 A Heptachlor epoxide (ug/L)

39342 A Lindane (ug/L)

82351 A Methoxychlor (ug/L)

39757 A Mirex (ug/L)

82349 A Perthane (ug/L)
.01
.01
.01
.1
.1
.01
.01
.01
.01
.01
.1
1.0

$176.00 \quad 800 \mathrm{~mL} \quad$ GCC

.01

.01

.01

.01

.01

.1

.01

.01

.01

.01

.1
1.0 


\begin{tabular}{llll}
\hline $\begin{array}{l}\text { Lab code } \\
\text { or } \\
\text { schedule }\end{array}$ Class & \begin{tabular}{l} 
WATSTORE \& $\begin{array}{l}\text { method } \\
\text { code }\end{array}$ \\
\hline
\end{tabular}
\end{tabular}

\section{Pesticides--Continued}

Organochlorine compounds--Continued

\begin{tabular}{|c|c|c|c|c|c|c|c|}
\hline $\begin{array}{l}\text { LCO806 } \\
\text { LC0807 } \\
\text { LCO808 }\end{array}$ & $\begin{array}{l}\text { Limited } \\
\text { Limited } \\
\text { Limited }\end{array}$ & $\begin{array}{l}39337 \text { A alpha-BHC, total recoverable (ug/L) } \\
39338 \text { A beta-BHC, total recoverable (ug/L) } \\
34259 \text { A delta-BHC, total recoverable (ug/L) }\end{array}$ & $\begin{array}{l}25.00 \\
25.00 \\
25.00\end{array}$ & $\begin{array}{l}800 \mathrm{~mL} \\
800 \mathrm{~mL} \\
800 \mathrm{~mL}\end{array}$ & $\begin{array}{l}\text { GCC } \\
\text { GCC } \\
\text { GCC }\end{array}$ & $\begin{array}{l}.01 \\
.01 \\
.01\end{array}$ & $\begin{array}{l}A \\
A \\
A\end{array}$ \\
\hline \multirow[t]{2}{*}{ SH1324 } & Regular & $\begin{array}{l}\text { Organochlorine insecticides with gross } \mathrm{PCB} \text { and } \mathrm{PCN} \text {, total } \\
\text { recoverable. }\end{array}$ & 159.00 & $800 \mathrm{~mL}$ & GCC & & \\
\hline & & $\begin{array}{l}39410 \text { C Heptachlor (ug/L) } \\
39420 \text { C Heptachlor epoxide (ug/L) } \\
39340 \text { C Lindane (ug/L) } \\
39480 \text { B Methoxychlor (ug/L) } \\
39755 \text { B Mirex (ug/L) }\end{array}$ & & & & $\begin{array}{l}.01 \\
.01 \\
.01 \\
.01 \\
.01\end{array}$ & \\
\hline \multirow{2}{*}{ SH1325 } & & $\begin{array}{l}39333 \text { A Aldrin (ug } / \mathrm{kg}) \\
39351 \text { A Chlordane (ug/kg) } \\
39363 \text { A DDD (ug/ } / \mathrm{kg}) \\
39368 \text { A DDE (ug/kg) } \\
39373 \text { A DDT (ug/kg) }\end{array}$ & & & & $\begin{array}{r}.1 \\
1.0 \\
.1 \\
.1 \\
.1\end{array}$ & \\
\hline & & (Schedule continued on next page) & & & & & \\
\hline
\end{tabular}

(Remarks: A, must be requested with appropriate schedule, e.g. SH1324.) 


\begin{tabular}{|c|c|c|c|c|c|c|c|c|}
\hline $\begin{array}{l}\text { Lab code } \\
\text { or } \\
\text { schedule }\end{array}$ & Class & $\begin{array}{l}\text { WATSTORE \& } \\
\text { method } \\
\text { code }\end{array}$ & Parameter name and unit of measurement & $\begin{array}{c}\text { Price } \\
(\$)\end{array}$ & $\begin{array}{l}\text { Sample } \\
\text { volume }\end{array}$ & $\begin{array}{l}\text { Sample } \\
\text { desig- } \\
\text { nation }\end{array}$ & $\begin{array}{l}\text { Reporting } \\
\text { level }\end{array}$ & Remarks \\
\hline
\end{tabular}

\section{Pesticides--Continued}

Organoch Torine compounds--Continued

SH1325

39383 A Dieldrin (ug/kg)

39389 A Endosulfan $(\mathrm{ug} / \mathrm{kg}$ )

39393 A Endrin ( $u g / k g)$

39519 A Gross polychlorinated biphenyls (ug/kg as PCB)

39251 A Gross polychlorinated naphthalenes (ug/kg as PCN)

39413 A Heptachlor (ug/kg)

39423 A Heptachlor epoxide (ug/kg)

39343 A Lindane (ug/kg)

39481 A Methoxychlor (ug/kg)

39758 A Mirex (ug/kg)

81886 A Perthane $(\mathrm{ug} / \mathrm{kg}$ )

39403 A Toxaphene (ug/kg)

Organophosphorus insecticides

SH1316 Regular
Organophosphorus insecticides, dissolved

-..-. Chlorpyrifos (ug/L)

39572 A Diazinon (ug/L)

- 2346 A A Eulfoton (ug/L)

... Fonofos (ug/L)

39532 A Malathion (ug/L)

39602 A Methyl parathion (ug/L)

82344 A Methyl trithion (ug/L)

39542 A Parathion (ug/L)

...- Phorate (ug/L)

82342 A Trithion (ug/L)
$150.00 \quad 800 \mathrm{~mL} \quad \mathrm{GCC}$ 
Table 4.3.--Organic Analyses--Cont inued

\begin{tabular}{cccc}
\hline $\begin{array}{c}\text { Lab code } \\
\text { or } \\
\text { schedule }\end{array}$ & Class & $\begin{array}{l}\text { WATSTORE \& } \\
\text { method } \\
\text { code }\end{array}$ & Parameter name and unit of measurement \\
\hline
\end{tabular}

Pesticides--Continued

Organophosphorus insecticides--Continued

SH1317 Regular

Organophosphorus insecticides, suspended recoverable

$164.00 \quad 800 \mathrm{~mL} \quad$ GCC

--- Chlorpyrifos; Dursban (ug/L)

39573 A Diazinon (ug/L)

----- Disulfoton (ug/L)

82347 A Ethion (ug/L)

Fonofos (ug/L)

39533 A Malathion (ug/L)

39603 A Methyl parathion (ug/L)

82345 A Methyl trithion (ug/L)

39543 A Parathion (ug/L)

-...- Phorate (ug/L)

82343 A Trithion (ug/L)

LC0802 Limited 39040 DEF, total recoverable (ug/L)

LC0805 Limited 39580 Azinphos-methyl, total recoverable (ug/L)

SH1319 Regular

Organophosphorus insecticides, total recoverable

$$
\begin{aligned}
& \text {-..-Chlorpyrifos (ug/L) } \\
& 39570 \text { B Diazinon (ug/L) } \\
& \text {-.--- Disulfoton (ug/L) } \\
& 39398 \text { B Ethion (ug/L) } \\
& \text { Fonofos (ug/L) }
\end{aligned}
$$

.01
.01
.01
.01
.01
.01
.01
.01
.01

39786 B Trithion (ug/L) 
홍

Table 4.3.---Organic Analyses---Continued

\begin{tabular}{|c|c|c|c|c|c|c|c|}
\hline $\begin{array}{l}\text { Lab code } \\
\text { or } \\
\text { schedule }\end{array}$ & Class & $\begin{array}{l}\text { WATSTORE \& Parameter name and unit of measurement } \\
\text { method } \\
\text { code }\end{array}$ & $\begin{array}{c}\text { Price } \\
(\$)\end{array}$ & $\begin{array}{l}\text { Sample } \\
\text { volume }\end{array}$ & $\begin{array}{l}\text { Sample } \\
\text { desig- } \\
\text { nation }\end{array}$ & $\begin{array}{l}\text { Reporting } \\
\text { level }\end{array}$ & Remarks \\
\hline \multicolumn{8}{|c|}{ Pesticides--Continued } \\
\hline \multirow[t]{4}{*}{ SH1320 } & Regular & $\begin{array}{l}\text { Organophosphorus insecticides, recoverable from bottom } \\
\text { material, dry wt. }\end{array}$ & 236.00 & $200 \mathrm{~g}$ & BGC & & \\
\hline & & \begin{tabular}{l} 
Ch lorpyrifos; Dursban (ug/L) \\
39571 A Diazinon (ug/kg) \\
\hdashline$\quad$ Disulfoton (ug/L) \\
39399 A Ethion (ug/ $/ \mathrm{kg})$
\end{tabular} & & & & $\begin{array}{l}.1 \\
.1 \\
.01 \\
.1\end{array}$ & \\
\hline & & $\begin{array}{l}39531 \text { A Malathion (ug/kg) } \\
39601 \text { A Methyl parathion }(\mathrm{ug} / \mathrm{kg}) \\
39791 \text { A Methy trithion (ug/kg) } \\
39541 \text { A Parathion (ug/kg) } \\
\end{array}$ & & & & $\begin{array}{l}.1 \\
.1 \\
.1 \\
.1\end{array}$ & \\
\hline & & 39787 A Trithion (ug/kg) & & & & .1 & \\
\hline \multicolumn{8}{|c|}{ Organochlorine compounds and organophosphorus insecticides } \\
\hline \multirow[t]{4}{*}{ SH1331 } & Regular & $\begin{array}{l}\text { Organochlorine compounds and organophosphorus insecticides } \\
\text { with gross PCB and gross PCN, dissolved }\end{array}$ & 243.00 & $800 \mathrm{~mL}$ & GCC & & \\
\hline & & $\begin{array}{l}39331 \text { A Aldrin (ug/L) } \\
39352 \text { A Ch lordane (ug/L) } \\
39361 \text { A DDD (ug/L) } \\
39366 \text { A DDE (ug/L) }\end{array}$ & & & & $\begin{array}{l}.01 \\
.1 \\
.01 \\
.01 \\
.01\end{array}$ & \\
\hline & & $\begin{array}{l}39371 \text { A DDT (ug/L) } \\
39572 \text { A Diazinon (ug/L) } \\
39381 \text { A Dieldrin (ug/L) } \\
32354 \text { A Endosulfan (ug/L) }\end{array}$ & & & & $\begin{array}{l}.01 \\
.01 \\
.01 \\
.01 \\
.01\end{array}$ & \\
\hline & & $\begin{array}{l}39391 \text { A Endrin (ug/L) } \\
82346 \text { A Ethion (ug/L) } \\
\text { 39517 A Grofos (ug/L) } \\
82360 \text { A Gross polychlorinated biphenyls (ug/L as PCB) } \\
\text { Fated naphthalenes (ug/L as PCN) }\end{array}$ & & & & $\begin{array}{l}.01 \\
.01 \\
.01 \\
.1 \\
.1\end{array}$ & \\
\hline
\end{tabular}




\begin{tabular}{|c|c|c|c|c|c|c|c|c|}
\hline $\begin{array}{l}\text { Lab code } \\
\text { or } \\
\text { schedule }\end{array}$ & Class & $\begin{array}{l}\text { WATSTORE \& } \\
\text { method } \\
\text { code }\end{array}$ & Parameter name and unit of measurement & $\begin{array}{l}\text { Price } \\
(\$)\end{array}$ & $\begin{array}{l}\text { Sample } \\
\text { volume }\end{array}$ & $\begin{array}{l}\text { Sample } \\
\text { desig- } \\
\text { nation }\end{array}$ & $\begin{array}{l}\text { Reporting } \\
\text { level }\end{array}$ & Remarks \\
\hline
\end{tabular}

\section{Pesticides--Continued}

volume nation

level

SH1331 39411 A Heptachlor (ug/L)

39421 A Heptachlor epoxide (ug/L)

39341 A Lindane (ug/L)

39532 A Malathion (ug/L)

82350 A Methoxychlor (ug/L)

39602 A Methyl parathion (ug/L)

82344 A Methyl trithion (ug/L)

39756 A Mirex (ug/L)

39542 A Parathion (ug/L)

82348 A Perthane (ug/L)

\section{-..-- Phorate (ug/L)}

39401 A Toxaphene (ug/L)

82342 A Trithion (ug/L)

.01

.01

.01

.01

.01

.01

.01

.01

1.01

.01

SH1332 Regular

Organochlorine compounds and organophosphorus insecticides with gross PCB and gross PCN, suspended recoverable

$260.00 \quad 800 \mathrm{~mL}$

GCC

39332 A Aldrin (ug/L)

39353 A Chlordane (ug/L)

-. Chlorpyrifos; Dursban (ug/L)

39362 A DDD (ug/L)

39367 A DDE (ug/L)

39372 A DDT (ug/L)

39573 A Diazinon (ug/L)

39382 A Dieldrin (ug/L)

---- Disulfoton (ug/L)

82355 A Endosulfan (ug/L)

39392 A Endrin (ug/L)

82347 A Ethion (ug/L)

-..- Fonofos (ug/L)

39518 A Gross polychlorinated biphenyls (ug/L as PCB)

82361 A Gross polychlorinated naphthalenes (ug/L as PCN)

(Schedule continued on next page) 


\begin{tabular}{|c|c|c|c|c|c|c|c|}
\hline $\begin{array}{l}\text { Lab code } \\
\text { or } \\
\text { schedule }\end{array}$ & $\begin{array}{l}\text { WATSTORE \& } \\
\text { Class } \begin{array}{l}\text { method } \\
\text { code }\end{array}\end{array}$ & Parameter name and unit of measurement & $\begin{array}{l}\text { Price } \\
(\$)\end{array}$ & $\begin{array}{l}\text { Sample } \\
\text { volume }\end{array}$ & $\begin{array}{l}\text { Sample } \\
\text { desig- } \\
\text { nation }\end{array}$ & $\begin{array}{l}\text { Reporting } \\
\text { leve } 1\end{array}$ & Remarks \\
\hline
\end{tabular}

\section{Pesticides--Continued}

SH1332

39412 A Heptachlor (ug/L)

39422 A Heptachlor epoxide (ug/L)

39342 A Lindane (ug/L)

39533 A Malathion (ug/L)

82351 A Methoxychlor (ug/L)

39603 A Methyl parathion (ug/L)

82345 A Methyl trithion (ug/L)

39757 A Mirex (ug/L)

39543 A Parathion (ug/L)

82349 A Perthane (ug/L)

----- Phorate (ug/L)

39402 A Toxaphene (ug/L)

82343 A Trithion (ug/L)

SH1334 Regular

Organochlorine compounds and organophosphorus insecticides with gross $\mathrm{PCB}$, gross $\mathrm{PCN}$, and methoxychlor, total recoverable

39330 C Aldrin (ug/L)

39350 B Chlordane (ug/L)

-..-- Ch Torpyrifos; Dursban (ug/L)

39360 C DDD (ug/L)

39365 C DDE (ug/L)

39370 C DDT (ug/L)

39570 B Diazinon (ug/L)

39380 C Dieldrin (ug/L)

-.-- Disulfoton (ug/L)

39388 C Endosulfan (ug/L)

39390 C Endrin (ug/L)

39398 B Ethion (ug/L)

-..- Fonofos (ug/L)

39516 B Gross polychlorinated biphenyls (ug/L as PCB)

39250 B Gross polychlorinated naphthalenes (ug/L as PCN) 
Table 4.3.--Organic Analyses--Cont inued

$\stackrel{t}{b}$

\begin{tabular}{|c|c|c|c|c|c|c|c|c|}
\hline $\begin{array}{l}\text { Lab code } \\
\text { or } \\
\text { schedu le }\end{array}$ & Class & $\begin{array}{l}\text { WATSTORE \& } \\
\text { method } \\
\text { code }\end{array}$ & Parameter name and unit of measurement & $\begin{array}{l}\text { Price } \\
(\$)\end{array}$ & $\begin{array}{l}\text { Samp le } \\
\text { volume }\end{array}$ & $\begin{array}{l}\text { Sample } \\
\text { desig- } \\
\text { nation }\end{array}$ & $\begin{array}{l}\text { Reporting } \\
\text { level }\end{array}$ & Remarks \\
\hline
\end{tabular}

\section{Pesticides--Continued}

Organochlorine compounds and organophosphorus insecticides--Continued

SH1334

39410 C Heptachlor (ug/L)

39420 C Heptachlor epoxide (ug/L)

39340 C Lindane (ug/L)

39530 B Malathion (ug/L)

39480 B Methoxychior (ug/L)

39600 B Methy 1 parathion (ug/L)

39790 B Methy 1 trithion (ug/L)

39755 B Mirex (ug/L)

39540 B Parathion (ug/L)

39034 A Perthane (ug/L)

-.-.- Phorate (ug/L)

39400 B Toxaphene (ug/L)

39786 B Trithion (ug/L)

.01

.01

.01

.01

.01

.01

.01

.01

1.0
.01

SH1399 Special

Organochlorine compounds and organophosphorus insecticides with gross PCB, gross PCN, and methoxychlor, total recoverable

39330 B Aldrin (ug/L)

39350 B ChTordane (ug/L)

- Chlorpyrifos; Dursban (ug/L)

39360 B DDD (ug/L)

39365 B DDE (ug/L)

39370 B DDT (ug/L)

39570 B Diazinon (ug/L)

39380 B Dieldrin (ug/L)

-.--. Disulfoton (ug/L)

39388 B Endosulfan (ug/L)
$290.00 \quad 800 \mathrm{~mL} \quad$ GCC

.001
.1
.01
.001
.001

.001
.01
.001
.01
.01




\begin{tabular}{|c|c|c|c|c|c|c|c|c|}
\hline $\begin{array}{l}\text { Lab code } \\
\text { or } \\
\text { schedule }\end{array}$ & Class & $\begin{array}{l}\text { WATSTORE \& } \\
\text { method } \\
\text { code }\end{array}$ & Parameter name and unit of measurement & $\begin{array}{l}\text { Price } \\
(\$)\end{array}$ & $\begin{array}{l}\text { Samp le } \\
\text { volume }\end{array}$ & $\begin{array}{l}\text { Sample } \\
\text { desig- } \\
\text { nation }\end{array}$ & $\begin{array}{l}\text { Reporting } \\
\text { level }\end{array}$ & Remarks \\
\hline
\end{tabular}

\section{Pesticides--Continued}

Organochlorine compounds and organophosphorus insecticides--Continued SH1399

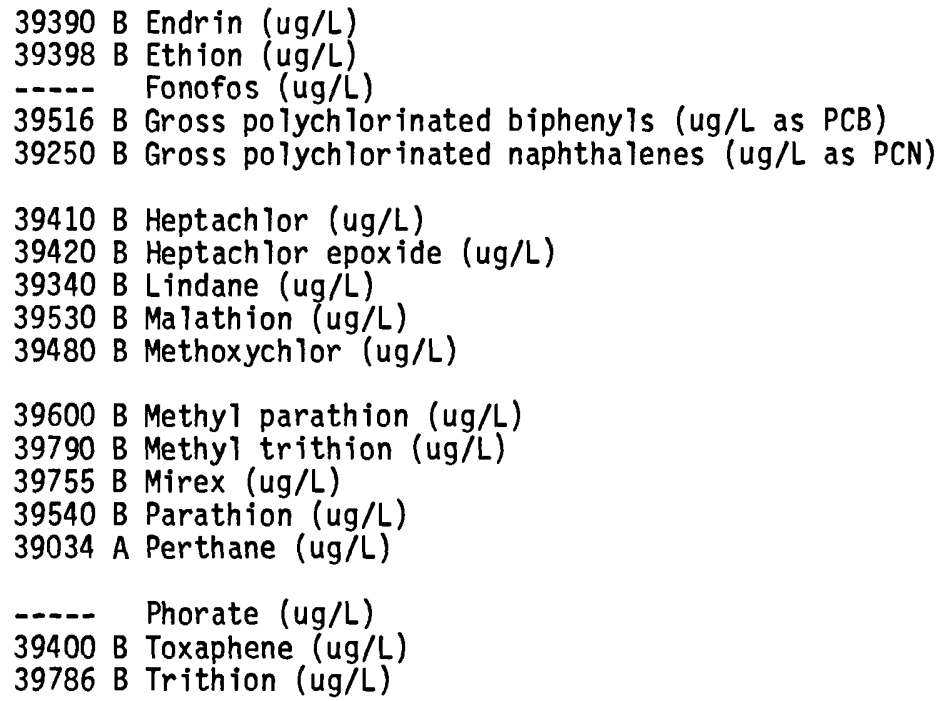

.001 


\begin{tabular}{|c|c|c|c|c|c|c|c|c|}
\hline $\begin{array}{l}\text { Lab code } \\
\text { or } \\
\text { schedule }\end{array}$ & Class & $\begin{array}{l}\text { WATSTORE \& } \\
\text { method } \\
\text { code }\end{array}$ & Parameter name and unit of measurement & $\begin{array}{c}\text { Price } \\
(\$)\end{array}$ & $\begin{array}{l}\text { Sample } \\
\text { volume }\end{array}$ & $\begin{array}{l}\text { Sample } \\
\text { desig- } \\
\text { nation }\end{array}$ & $\begin{array}{l}\text { Reporting } \\
\text { level }\end{array}$ & Remarks \\
\hline
\end{tabular}

\section{Pesticides--Cont inued}

Organochlorine compounds and organophosphorus insecticides--cont inued
SH1335 ReguTar
Organochlorine compounds and organophosphorus insecticides,
$457.00 \quad 200 \mathrm{~g}$
BGC recoverable from bottom material, dry wt.

457.0012009
Be

39333 A Aldrin (ug/ $/ \mathrm{kg})$

39351 A Chlordane (ug/kg)

---- Chlorpyrifos; Dursban (ug/L)

39363 A DDD (ug/ $/ \mathrm{kg})$

39368 A DDE (ug/kg)

39373 A DDT (ug/kg)

39571 A Diazinon (ug/ $/ \mathrm{kg}$ )

39383 A Dieldrin (ug/kg)

39389 A Endosulfan (ug/kg)

39393 A Endrin (ug/kg)

39399 A Ethion (ug/kg)

39519 A Gross polychlorinated biphenyls (ug/ $/ \mathrm{kg}$ as PCB)

39251 A Gross polychlorinated naphthalenes (ug/kg as PCN)

39413 A Heptachlor (ug/ $/ \mathrm{kg}$ )

39423 A Heptachlor epoxide (ug/kg)

39343 A Lindane (ug $/ \mathrm{kg}$ )

39531 A Malathion (ug/kg)

39481 A Methoxychlor (ug/ $/ \mathrm{kg}$ )

39601 A Methyl parathion (ug/kg)

39791 A Methyl trithion (ug/ $/ \mathrm{kg}$ )

39758 A Mirex $(u g / k g)$

39541 A Parathion (ug/ $/ \mathrm{kg}$ )

81886 A Perthane $(\mathrm{ug} / \mathrm{kg})$

39403 A Toxaphene (ug/ $/ \mathrm{kg})$

39787 A Trithion (ug/kg) 


\begin{tabular}{|c|c|c|c|c|c|c|c|c|}
\hline $\begin{array}{l}\text { Lab code } \\
\text { or } \\
\text { schedule }\end{array}$ & Class & $\begin{array}{l}\text { WATSTORE \& } \\
\text { method } \\
\text { code }\end{array}$ & Parameter name and unit of measurement & $\begin{array}{c}\text { Price } \\
(\$)\end{array}$ & $\begin{array}{l}\text { Sample } \\
\text { volume }\end{array}$ & $\begin{array}{l}\text { Sample } \\
\text { desig- } \\
\text { nation }\end{array}$ & $\begin{array}{l}\text { Reporting } \\
\text { level }\end{array}$ & Remarks \\
\hline
\end{tabular}

\section{Pesticides--Continued}

SH1474 Regular

Organoch lor ine, organophosphorus, and phenoxy acid compounds,

$460.00 \quad 1600 \mathrm{~mL} \quad$ GCC

total recoverable. Includes specific analys is for com-

pounds listed in SH1304, SH1319, and SH1324.

Triazines and other nitrogen-containing herbicides

Triazines and other nitrogen-containing herbicides, total recoverable

$230.00 \quad 800 \mathrm{~mL} \quad$ GCC

$$
\begin{aligned}
& 77825 \text { C Alachlor (ug/L) } \\
& 82184 \text { A Ametryn (ug/L) } \\
& 39630 \text { A Atrazine (ug/L) } \\
& 81757 \text { A Cyanazine (ug/L) } \\
& 82612 \text { C Metolachlor (ug/L) } \\
& 82611 \text { C Metribuzin (ug/L) } \\
& 39056 \text { A Prometon (ug/L) } \\
& 39057 \text { A Prometryn (ug/L) } \\
& 39024 \text { A Propazine (ug/L) } \\
& 39055 \text { A Simazine (ug/L) } \\
& 39054 \text { A Simetryn (ug/L) } \\
& 39030 \text { C Trifluratin (ug/L) }
\end{aligned}
$$

.1
.1
.1
.1
.1
.1
.1
.1
.1
.1
.1
.1


Part 5: Indices of Analytical Methodology and Chemical Abstract Services (CAS) Numbers 



\section{Introduction}

The precision numbers shown in Tables 5.2 (Inorganic) and 5.3.1 (Organic) were computed as the relative standard deviation (coefficient of variation) of a set of determinations. Each number is associated with the low, medium, and high concentration of the analytical range. Not all of the precision values have the same degree of reliability because data of different types were used in arriving at values reported in these tables. Precision data based on multi-laboratory values are considered more reliable than values based on single-laboratory, multiple-operator data; similarly, values based on multiple-operator data are considered more reliable than values based on single-operator data. Furthermore, precision values based on analyses of natural waters are considered more reliable than values based on analyses of pure solutions prepared in the 1aboratory.

Precision values shown in the catalog are intended to be used as a guide in requesting analyses. An alpha-numeric code is associated with each set of precision values. The alpha character refers to the list on page 5-2, "Methods used to derive precision values" and the numeric value refers to the list on page 5-3, "Sources and references for precision data." The alpha-numeric code provides a rough means of identifying the type of sample on which the precision is based and gives a reference which should be consulted prior to any interpretation of the data.

It should be noted that total, total recoverable, and bottom material precision data in the catalog are generally estimates based on dissolved, multilab precision data. Also, in order to make a realistic comparison of

one table value with another, single-operator precision values were multiplied by an arbitrary factor of three to avoid giving the requestors a false sense of confidence in the precision of the data they receive. 


\section{Methods used to derive precision values \\ (In order of decreasing confidence in the values used)}

A. Multilaboratory, natural (or contaminated) water precision data available at or near the designated level. Data may be preliminary or may be based on results from a limited number of samples or concentration levels.

B. Multilaboratory, deionized water precision data available at or near the designated level. Where it is not clear whether multilaboratory data were obtained using natural or distilled water, this letter, "B", is used.

C. Single laboratory, multiple operator, natural water precision data available at or near the designated level. May be expected to be a smaller value than that of "A".

D. Single laboratory, multiple operator, deionized water precision data available at or near the designated leve1. May be expected to be a smaller value than that of "B".

E. Single operator, natural water precision data available at or near the designated level. The value is likely to be half or less than "A" type data; so that the data user will not feel a false confidence in the value, an arbitrary multiplication factor of three was used in calculating category "E" data.

F. Single operator, distilled water precision data available at or near the designated level. The value is likely to be half or less than "B" type data; so that the data user will not feel a false confidence in the value, an arbitrary multiplication factor of three was used in calculating category "F" data.

G. Estimate of total, total recoverable, and bottom material precision based on dissolved, multilaboratory precision data.

H. Estimate of total, total recoverable, and bottom material precision based on dissolved, single laboratory precision data.

I. Estimate of total, total recoverable, and bottom material precision based on dissolved, single operator precision data.

J. Estimate of precision based on precision data from a similar method. For example, data are available for a manual, but not for the automated procedure.

K. Completely unsupported estimate found in the literature. (For example "although no data are available, the precision should be ...." ). 


\section{Sources and references for precision data}

1. American Public Health Association and others, 1985, Standard methods for the examination of water and wastewater (16th ed.): Washington, D.C., American Public Health Association, 1193 p.

2. Fishman, M. J., Bradford, W. L., 1982, Methods for the determination of inorganic substances in water and fluvial sediments: U.S. Geological Survey, Open-file report 82-272, 136 p.

3. Fishman, M. J., Pyen, G. 1979, Determination of selected anions in water by ion chromatography: U.S. Geological Survey, Lakewood, Colorado, Water-Resources Investigations 79-101,

4. Greeson, P. E., 1979, A supplement to methods for collection and analys is of aquatic biological and microbiological samples: U.S. Geological Survey, Open-file report 79-1279, 92 p.

5. McGirr, D. J., 1974, Specific conductance, $\mathrm{pH}$, colour, and residue: Interlaboratory Quality Control Study No. 6, Report Series No. 28, Information Canada, $6 \mathrm{p}$.

6. Sherma, J. B., Morton, 1981, Manual of analytical quality control for pesticides and related compounds: U.S. Environmental Protection Agency, Research Triangle Park, N.C., 455 p.

7. Fishman, M. J., Friedman, L. C., 1989, Methods for the analyses of inorganic substances in water and fluvial sediment: U.S. Geological Survey, Techniques of Water-Resources Investigations, Book 5 , Chapter A1, $626 \mathrm{p}$.

8. Thatcher, L.L., Janzer, V.J., Edwards, K. W., 1977, Methods for determinations of radioactive substances in water and fluvial sediments: U.S. Geological Survey, Techniques of Water-Resources Investigations, Book 5, Chapter A 5, 95 p.

9. U.S. Environmental Protection Agency, 1983, Methods for chemical analyses of water and wastes: U.S. Environmental Protection Agency, Cincinnati, Ohio.

10. U.S. Geological Survey, Unpublished data, on file in the National Water Quality Laboratory, Denver, Colorado.

11. Wershaw, R. L., Fishman, M. J., Grabbe, R.R., and Lowe, L.E., 1987 Methods for the determination of organic substances in water and fluvial sediments: U.S. Geological Survey, Techniques of WaterResources Investigations, Book 5, Chapter A 3, 80 p. 
5-4 


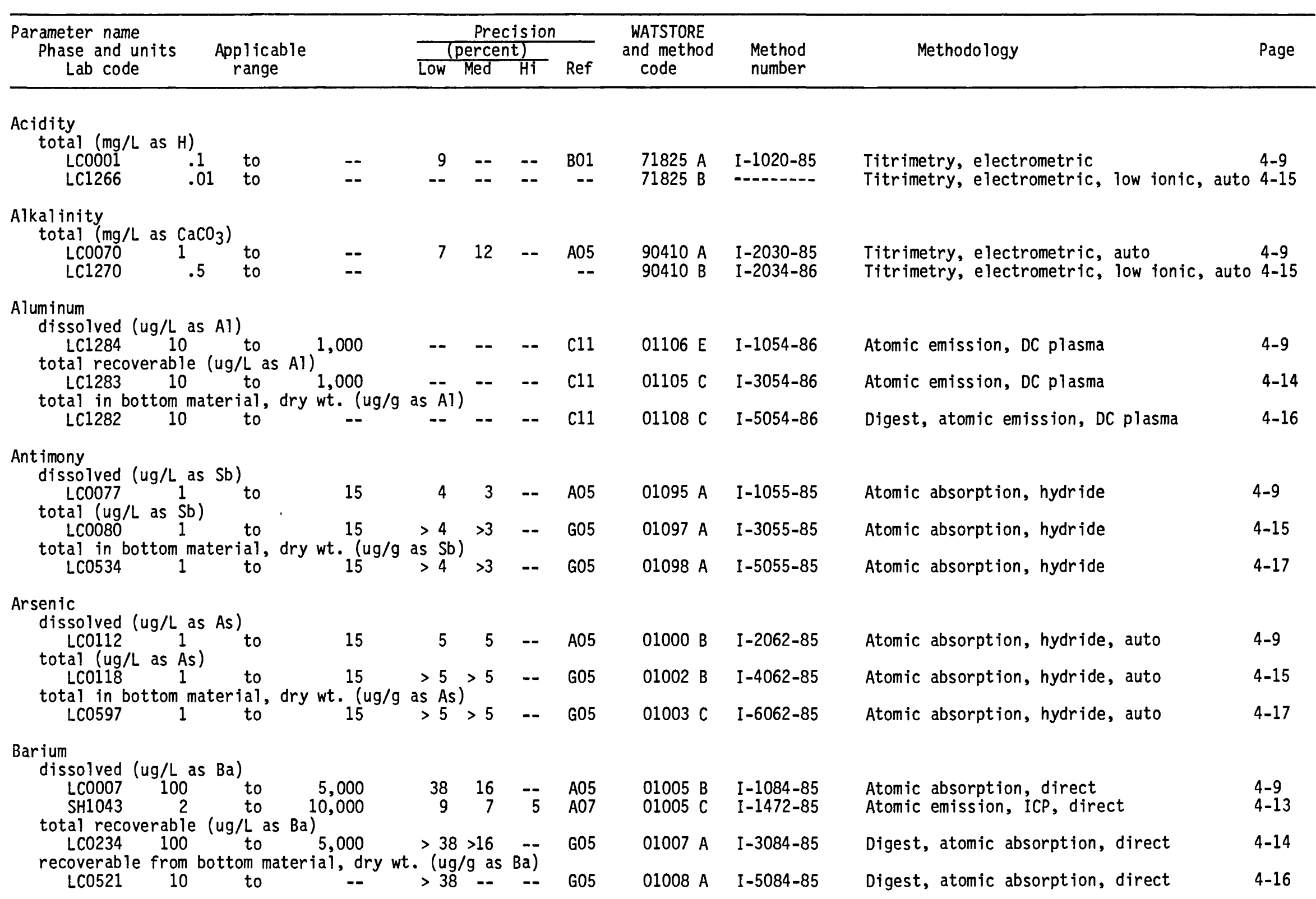




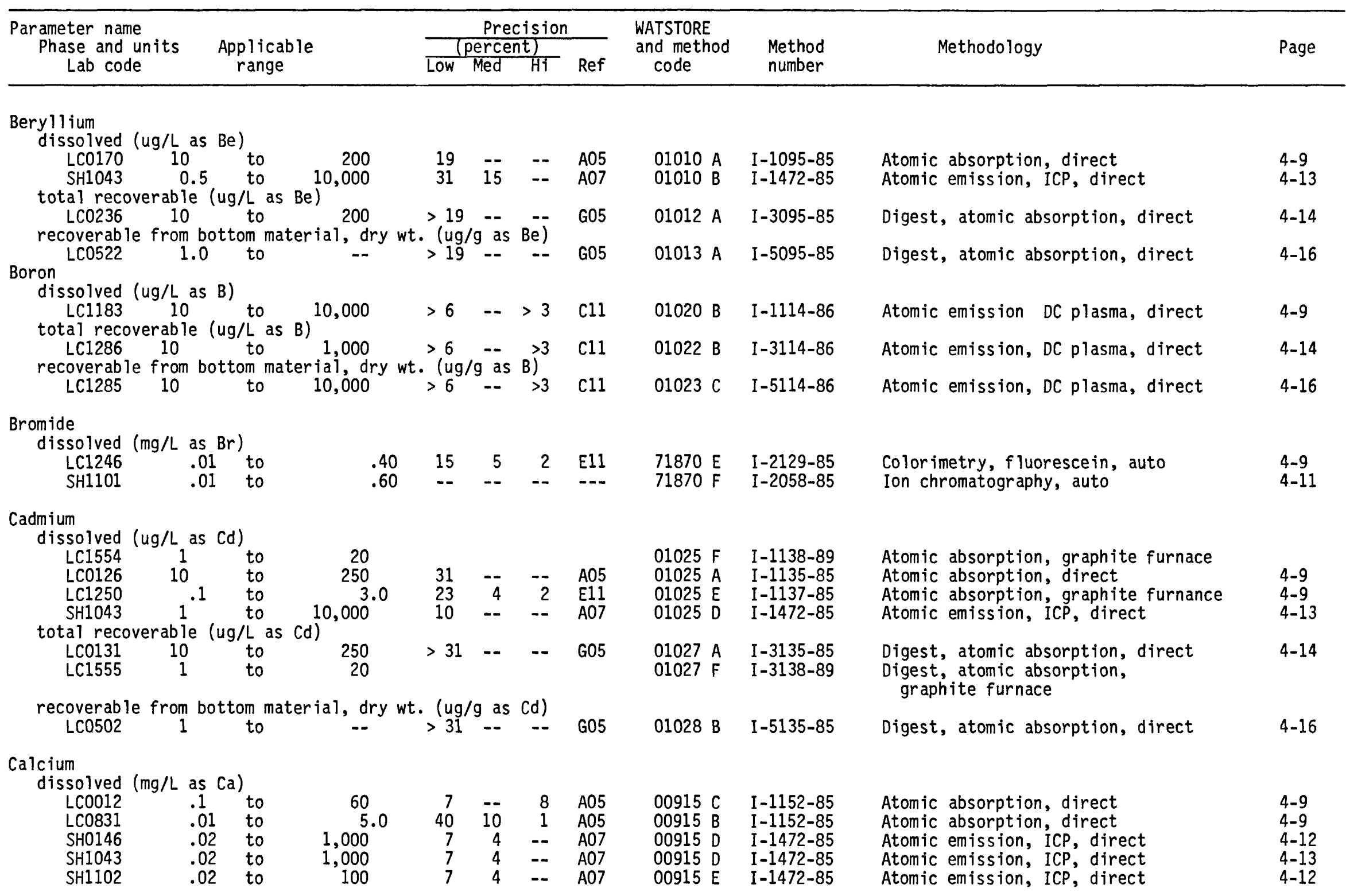




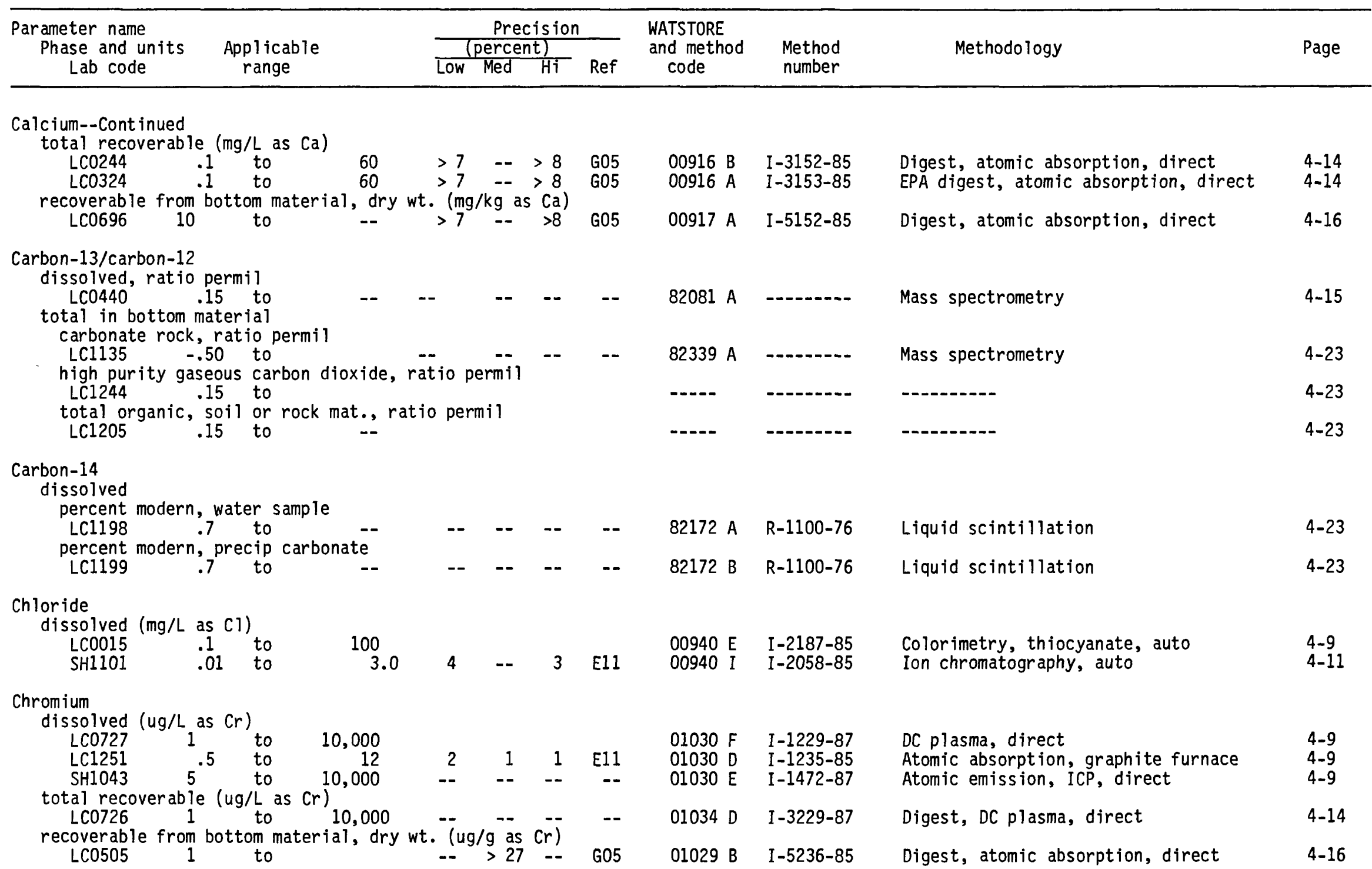




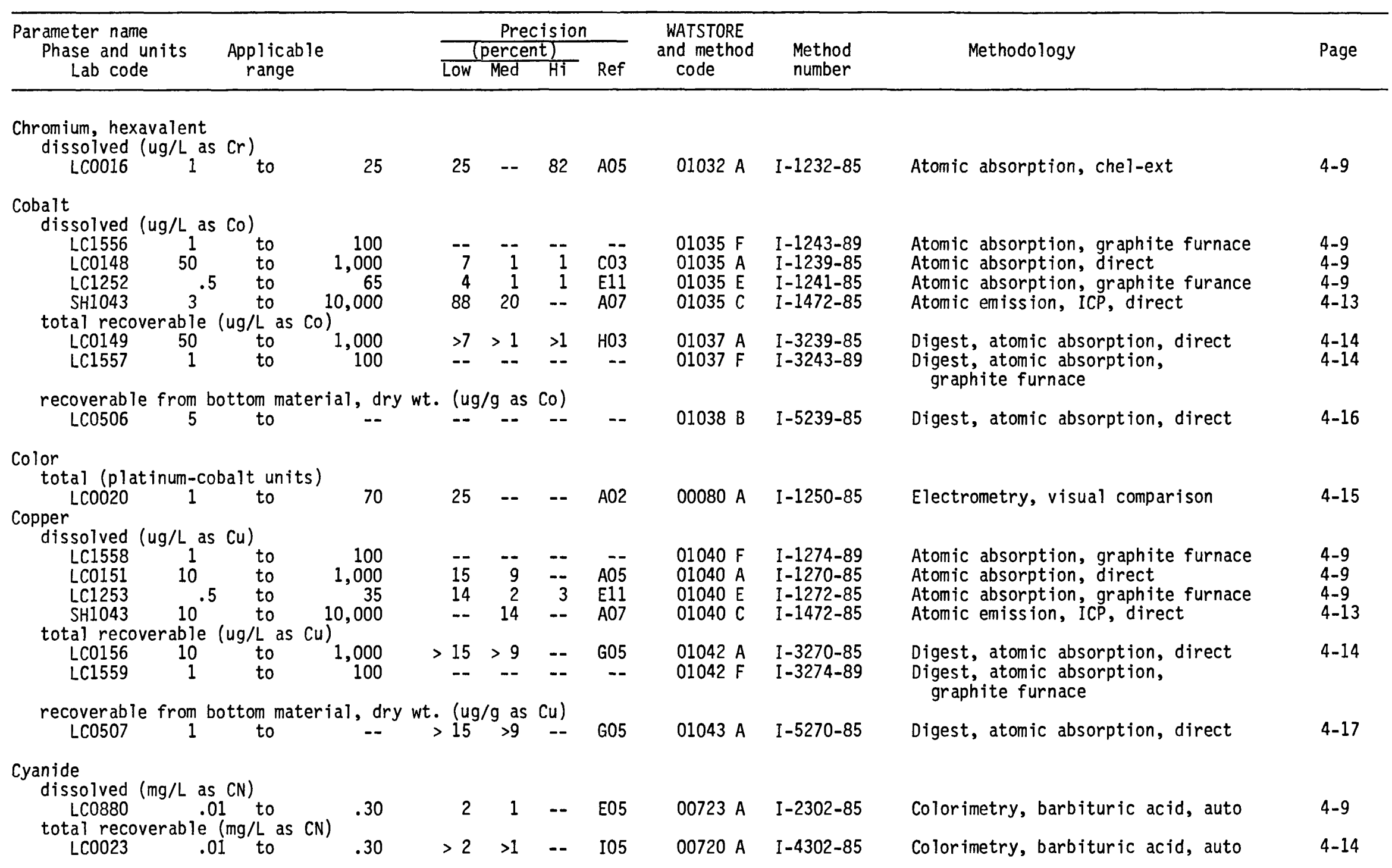


Table 5.2.--Index of analytical methodology for inorganic analyses--Continued

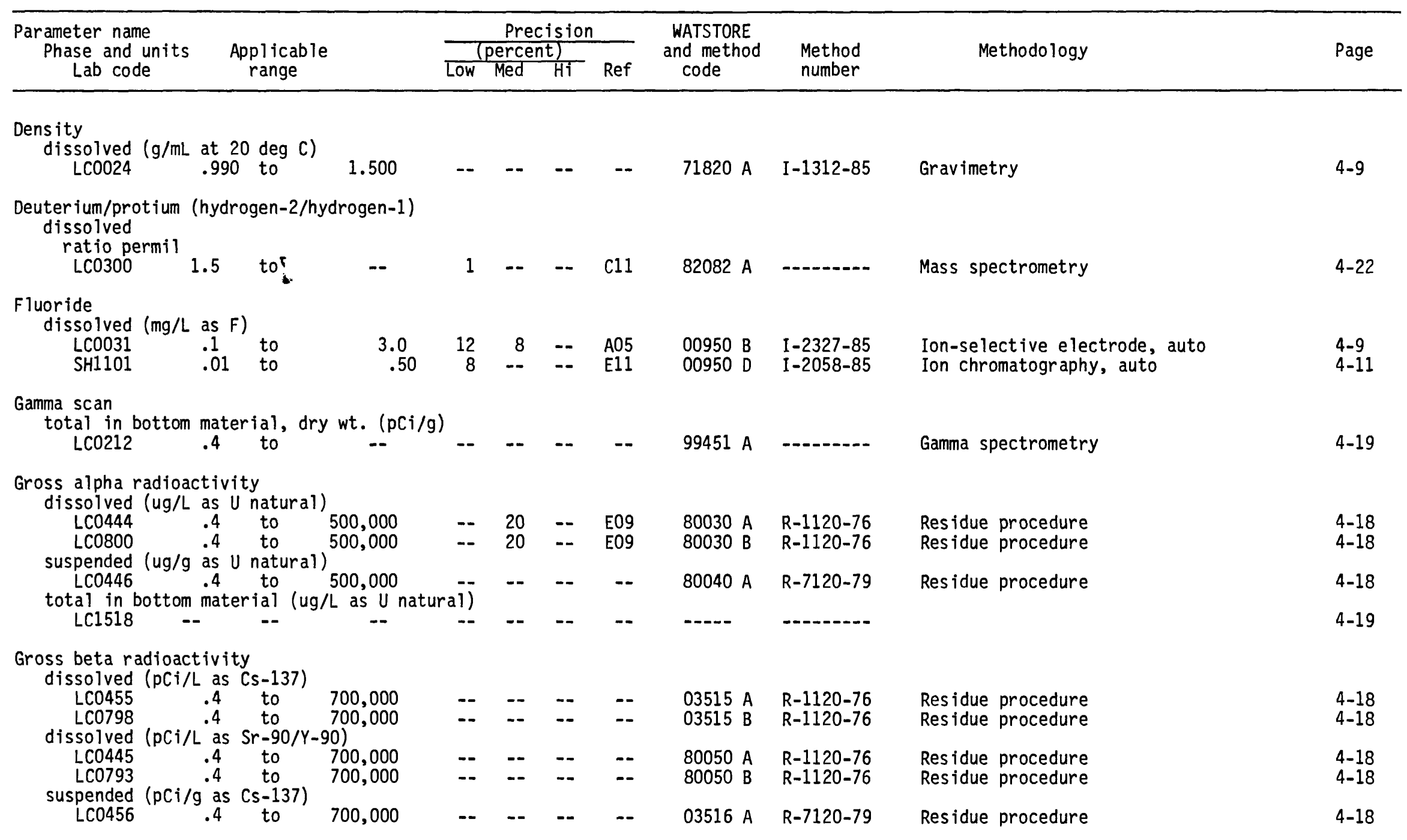


Table 5.2.--Index of analytical methodology for inorganic analyses--Continued

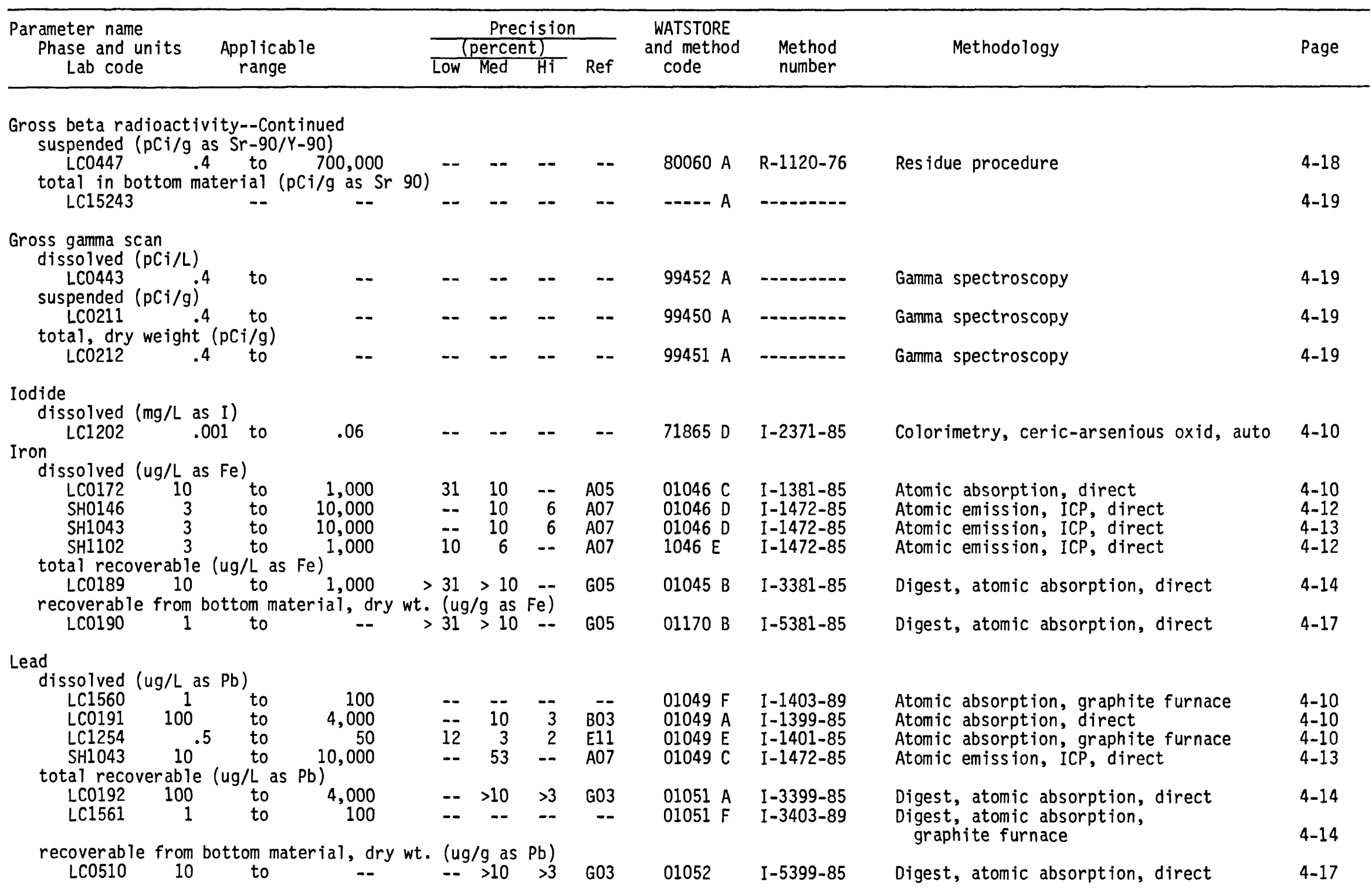




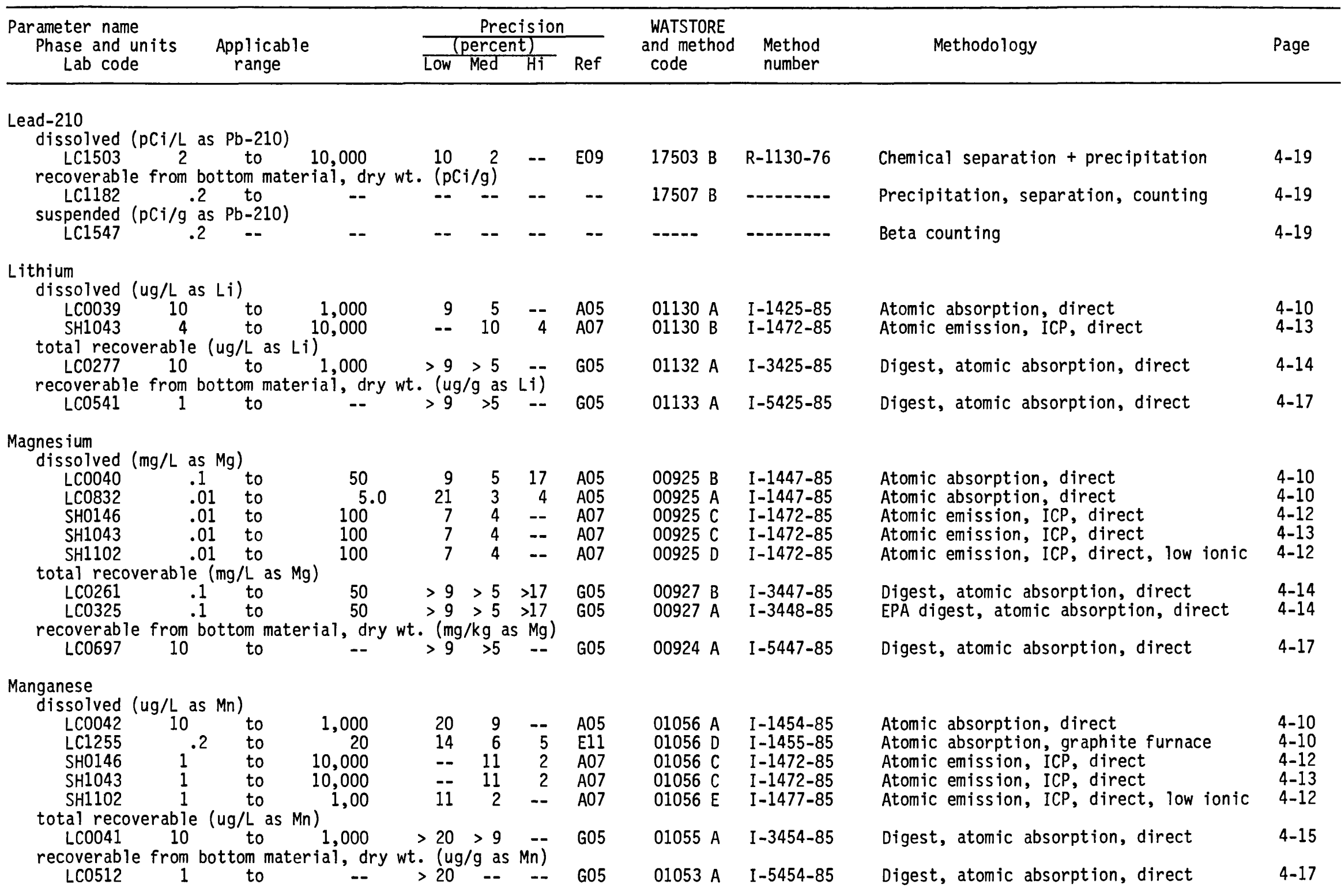




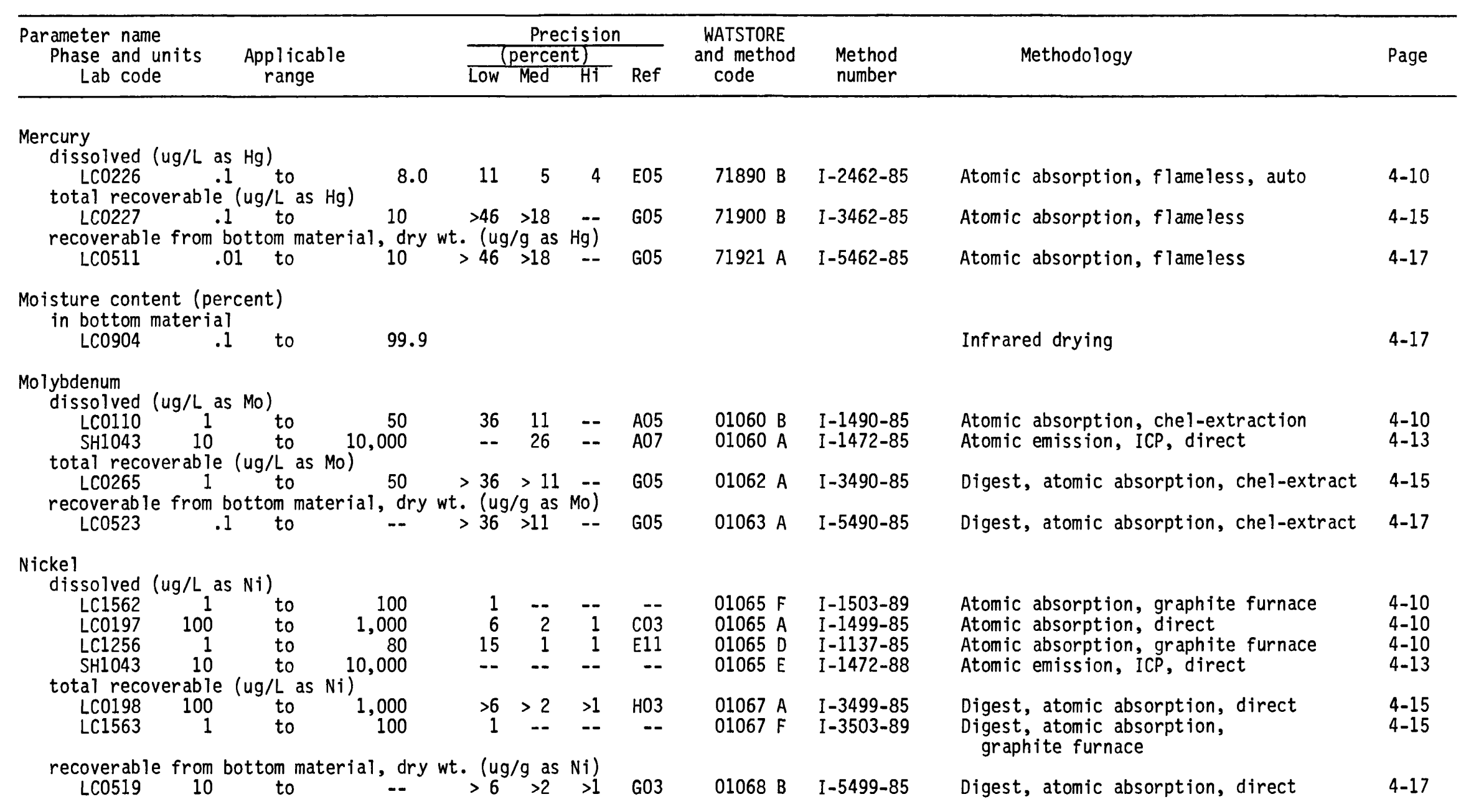




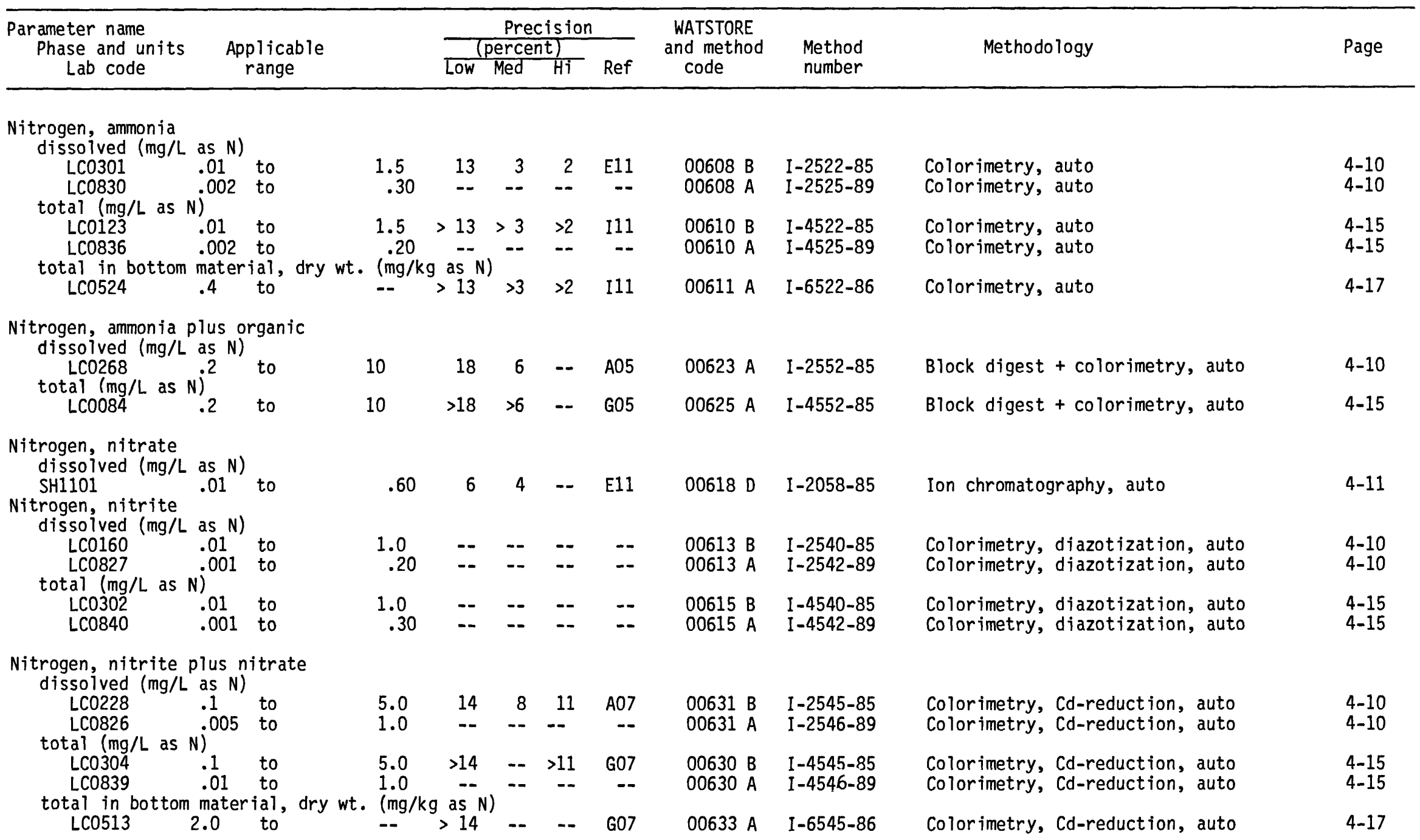




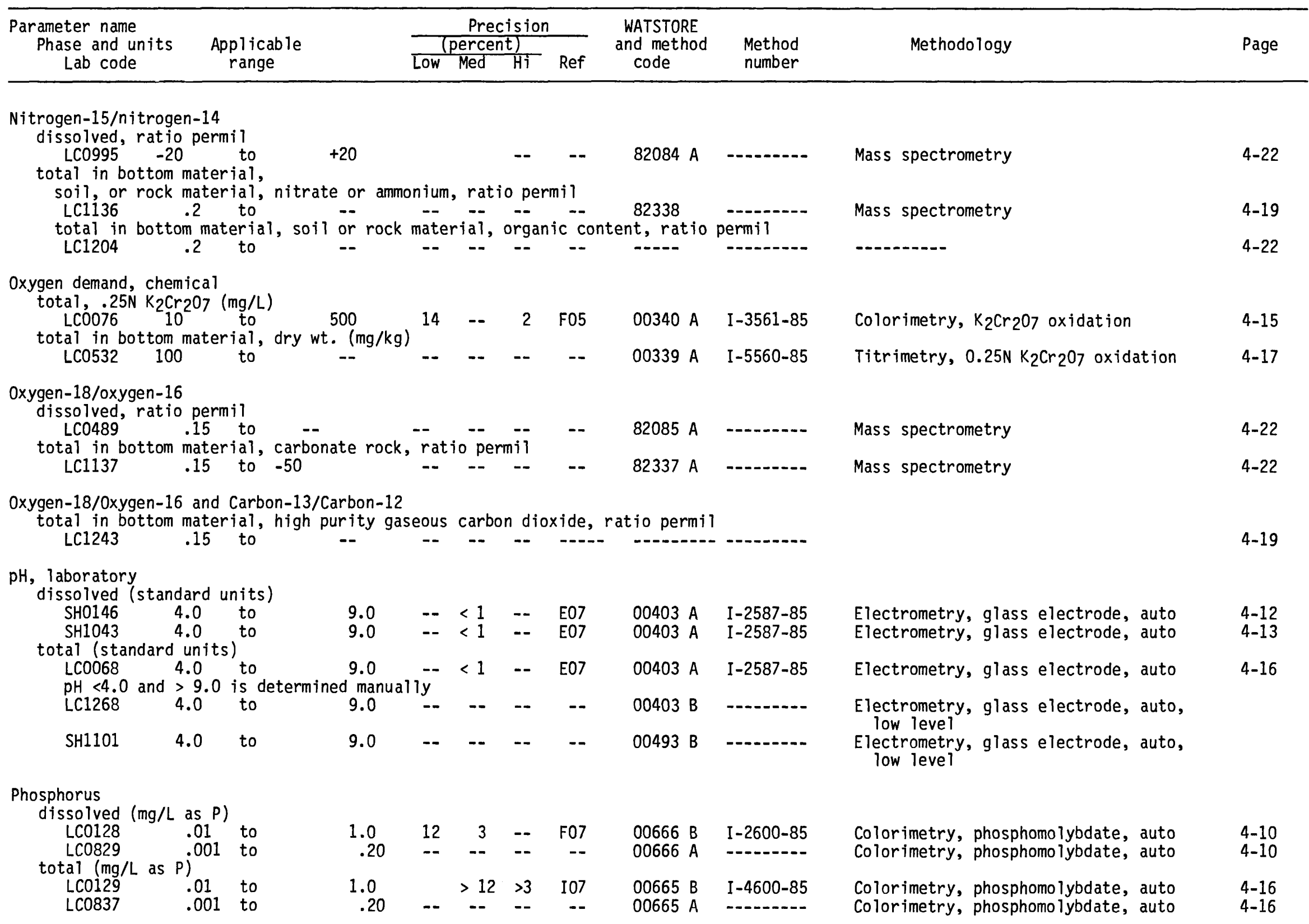




\begin{tabular}{|c|c|c|c|c|c|c|c|}
\hline \multirow{2}{*}{$\begin{array}{l}\text { Parameter name } \\
\text { Phase and units } \\
\text { Lab code }\end{array}$} & \multirow[b]{2}{*}{$\begin{array}{l}\text { Applicable } \\
\text { range }\end{array}$} & \multicolumn{2}{|l|}{ Precision } & \multirow{2}{*}{$\begin{array}{l}\text { WATSTORE } \\
\text { and method } \\
\text { code }\end{array}$} & \multirow[b]{2}{*}{$\begin{array}{l}\text { Method } \\
\text { number }\end{array}$} & \multirow[b]{2}{*}{ Methodology } & \multirow[b]{2}{*}{ Page } \\
\hline & & $\frac{\text { (percent) }}{\text { Low Med Hi }}$ & Ref & & & & \\
\hline
\end{tabular}

Phosphorus--Continued

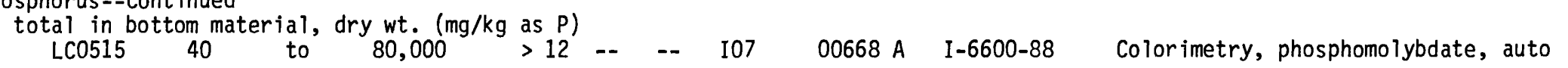

4-17

Phosphorus, hydrolyzable plus orthophosphate dissolved (mg/L as P) $\mathrm{LCO} 279$
total $(\mathrm{mg} / \mathrm{L}$ as $\mathrm{P})$
$\mathrm{LCO} O 282$

$\begin{array}{lllllll}1.0 & >12 & -- & -- & \mathrm{I} 07 & 00677 \text { A } & \mathrm{I}-2602-85 \\ 1.0 & >12 & -- & -- & 107 & 00678 \text { A } & \text { I-4602-85 }\end{array}$

Colorimetry, phosphomolybdate, auto

4-10

LCO282 to

Colorimetry, phosphomolybdate, auto

4-16

Phosphorus, orthophosphate
dissolved (mg/L as P)

$\begin{array}{ccc}\text { LCO162 } & .01 & \text { to } \\ \text { LCO828 } & .001 & \text { to } \\ \text { SH1101 } & .01 & \text { to } \\ \text { total (mg/L as } & \text { P) } & \\ \text { LC0297 } & .01 & \text { to } \\ \text { LCO838 } & .001 & \text { to }\end{array}$

$\begin{array}{cccccccc}1.0 & 20 & -- & -- & F 07 & 00671 \text { B } & \text { I-2601-86 } \\ .50 & -- & -- & -- & -- & 00671 \text { A } & \text { I-2606-89 } \\ .60 & 9 & -- & -- & \text { E11 } & 00671 \text { G } & \text { I }-2058-85 \\ 1.0 & >20 & -- & -- & \text { I07 } & 70507 \text { A } & \text { I }-4601-86 \\ .50 & -- & -- & -- & -- & 70507 \text { B } & \text { I-4609-89 }\end{array}$

Colorimetry, phosphomolybdate, auto Colorimetry, phosphomolybdate, auto Ion chromatography, auto

4-10

Colorimetry, phosphomolybdate, auto

Colorimetry, phosphomolybdate, auto

4-11

Polonium-210

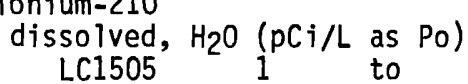

suspended ( $\mathrm{pCi} / \mathrm{g}$ as $\mathrm{Po})$

LC1543 .01 to
recoverable from bottom material $(\mathrm{pCi} / \mathrm{g}$ as $\mathrm{Po})$ LC1545 0.1 to

material ( $\mathrm{pCi} / \mathrm{g}$ as $\mathrm{PO})$

Potassium

dissolved (mg/L as $\mathrm{K}$ )

$\begin{array}{rc}\text { LCO054 } & .1 \\ \text { LC0833 } & .01\end{array}$

total recoverable .01 to $(\mathrm{mg} / \mathrm{L}$ as $K$ )

LCO321

. 1 to

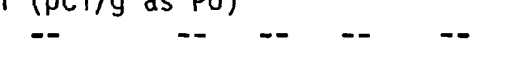

19503 A

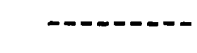

- - - - - - - - - - -

19507

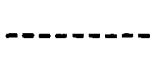

Alpha spectrometry

Alpha spectrometry

4-19

Alpha spectrometry

4-19

$100>14 \quad--\quad--\quad G 05$

recoverable from bottom material, dry wt. (mg/kg as K)

LC0698 10 to 10 -. 14 -. 605

00935 B $\quad$ I $-1630-85$

00935 A $\quad I-1630-85$

00937 B $\quad I-3630-85$

00937 A $\quad I-3631-85$

00938 A I-5630-85

Atomic absorption, direct

Atomic absorption, direct

4-11

Digest, atomic absorption, direct

EPA digest, atomic absorption, direct

$4-15$

Digest, atomic absorption, direct

$4-15$

Radium-226

dissolved ( $\mathrm{pCi} / \mathrm{L}$ as $\mathrm{Ra}-226$ )

$\begin{array}{llllllll}\text { LCO449 } & .01 & \text { to } & 1,000 & 20 & 10 & 10 & \text { E09 } \\ \text { LCO458 } & .1 & \text { to } & 1,000 & -- & 20 & 20 & \text { E09 } \\ \text { LC0794 } & .01 & \text { to } & 1,000 & 20 & 10 & 10 & \text { E09 } \\ \text { LC0799 } & .1 & \text { to } & 1,000 & -- & 20 & 20 & \text { E09 }\end{array}$

09511 A R $-1141-76$

09510 A $R-1140-76$

09511 B $R-1141-76$

09510 B R-1140-76

Radon emanation

Precipitation, planchet counting

Radon emanation

Precipitation, planchet counting 
Table 5.2.--Index of analytical methodology for inorganic analyses--Continued

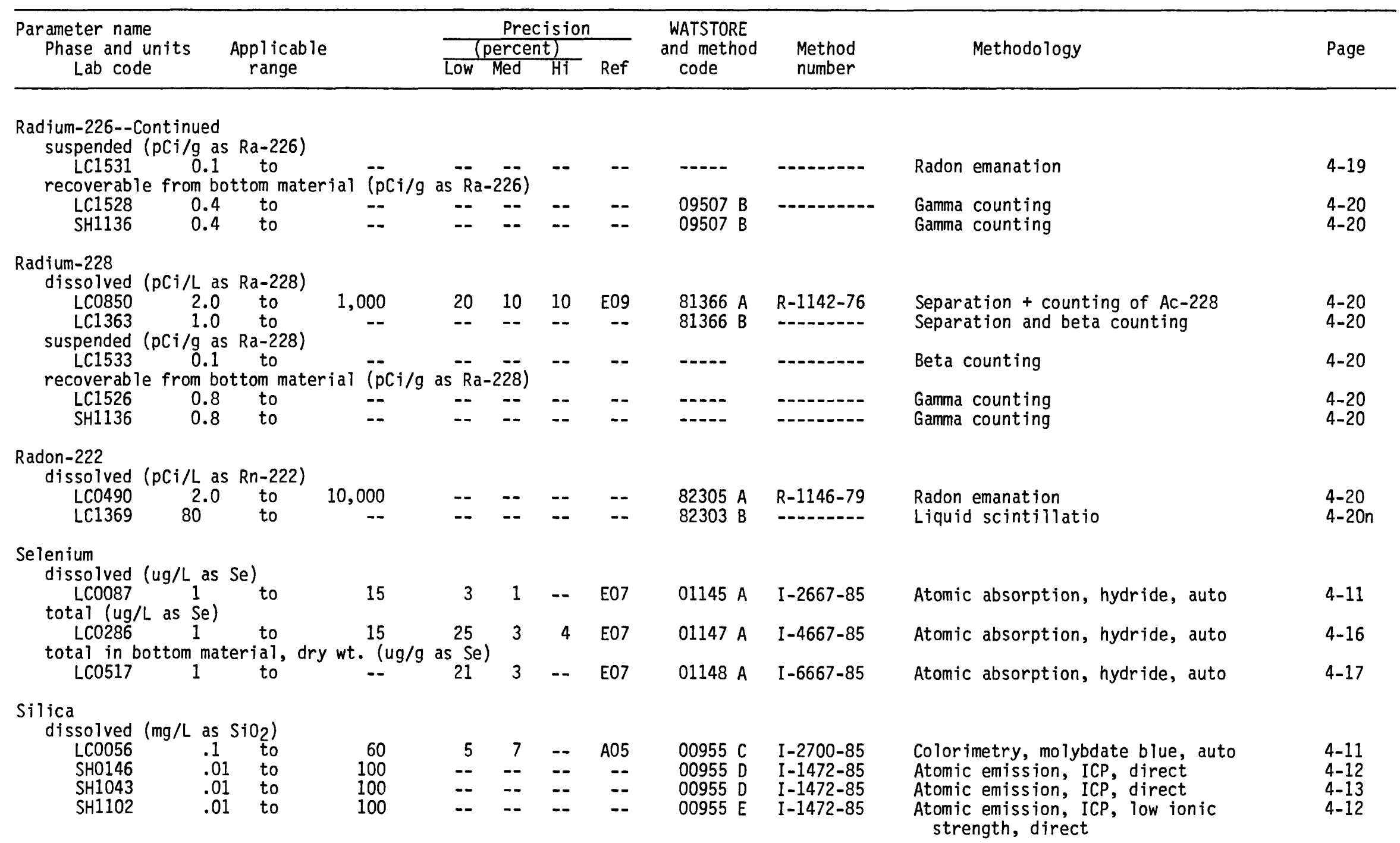




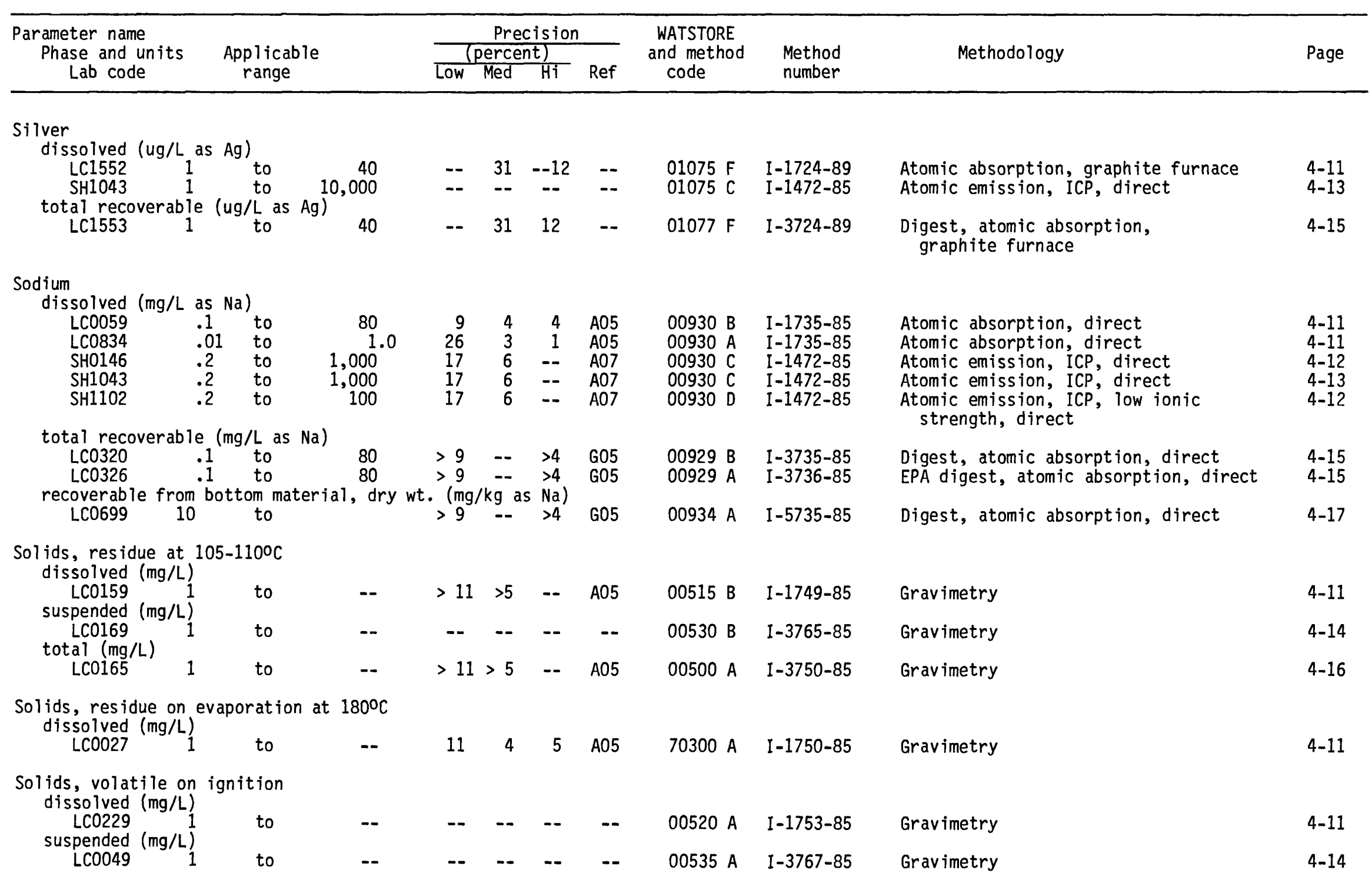




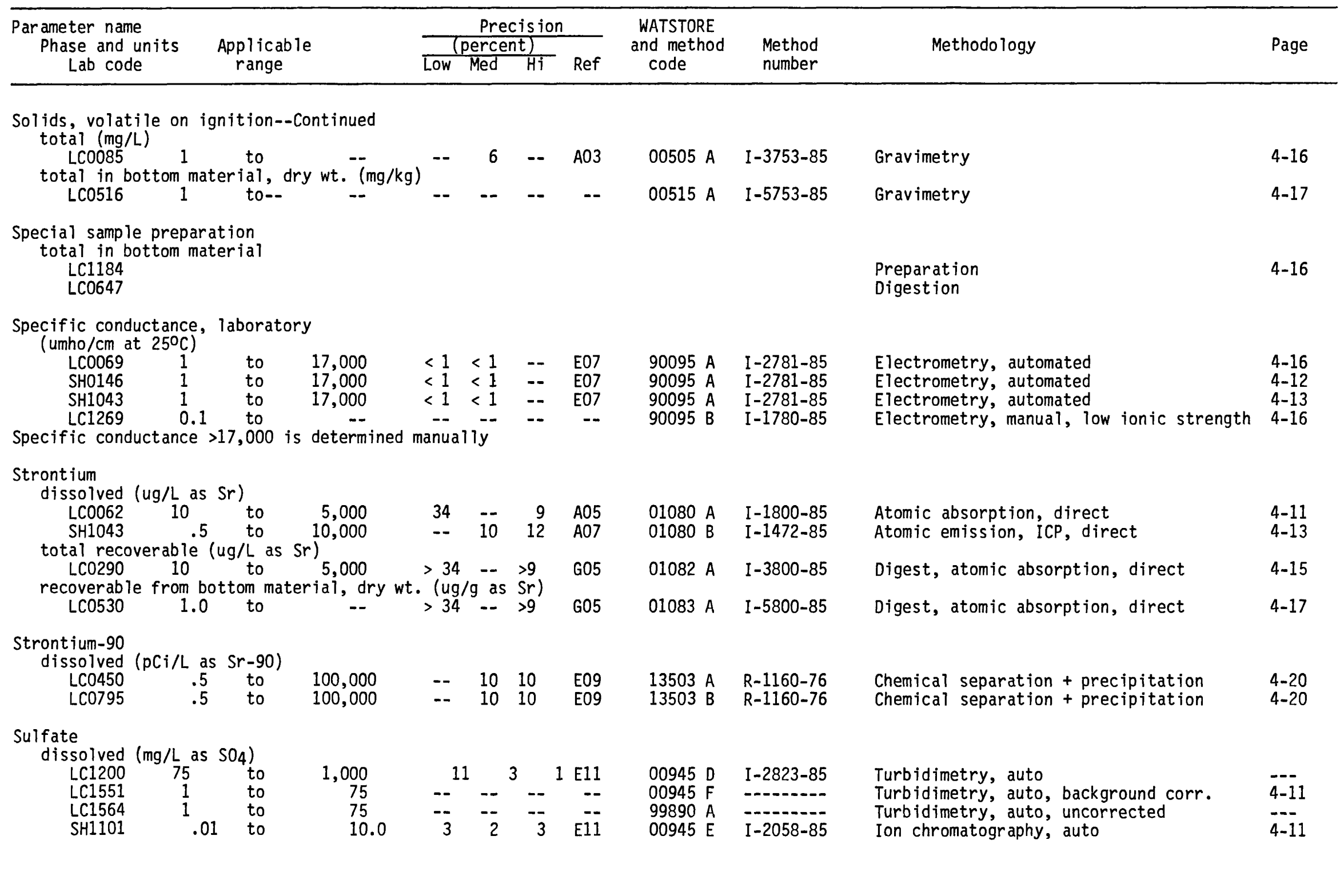




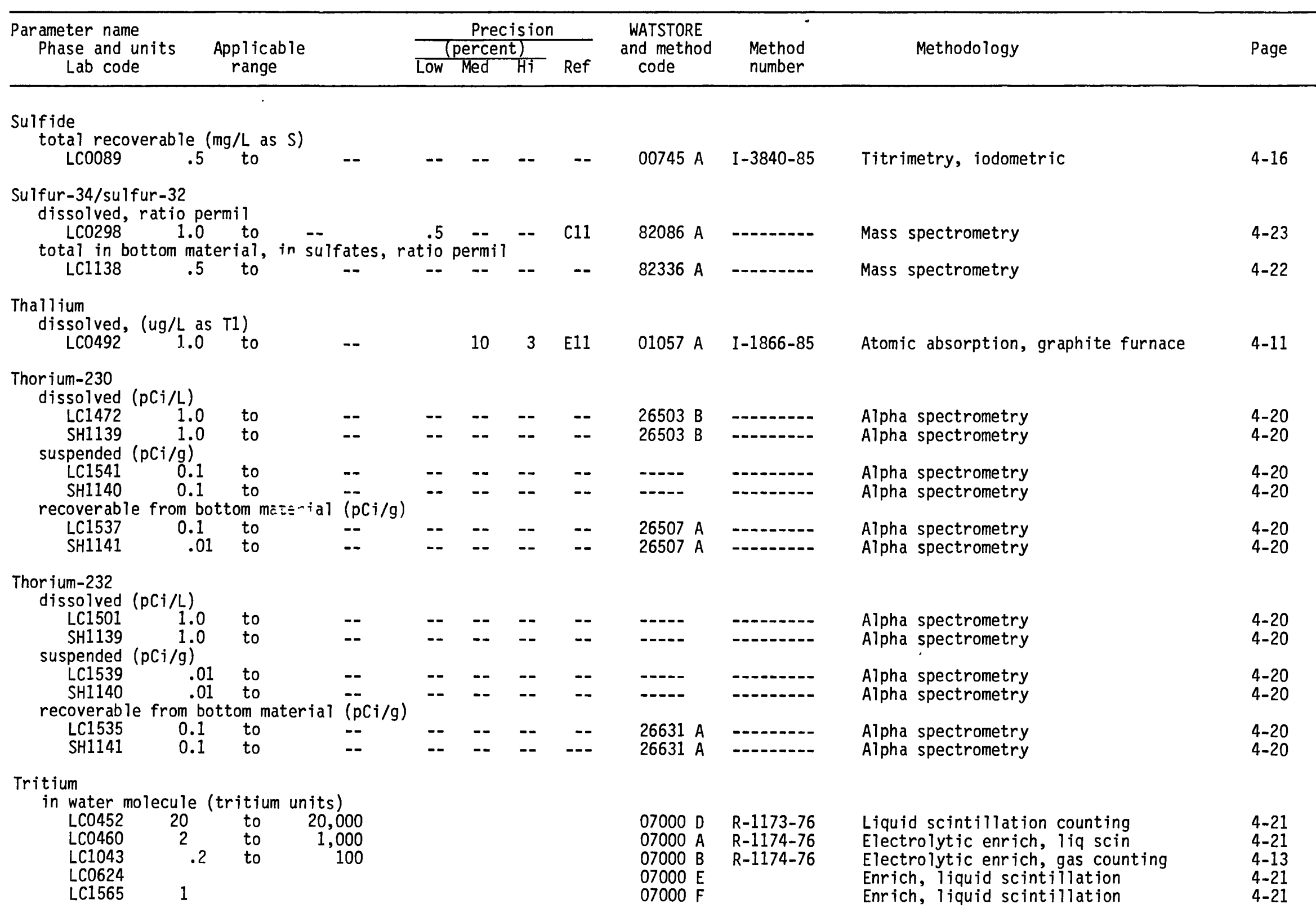


Table 5.2.--Index of analytical methodology for inorganic analyses--Continued

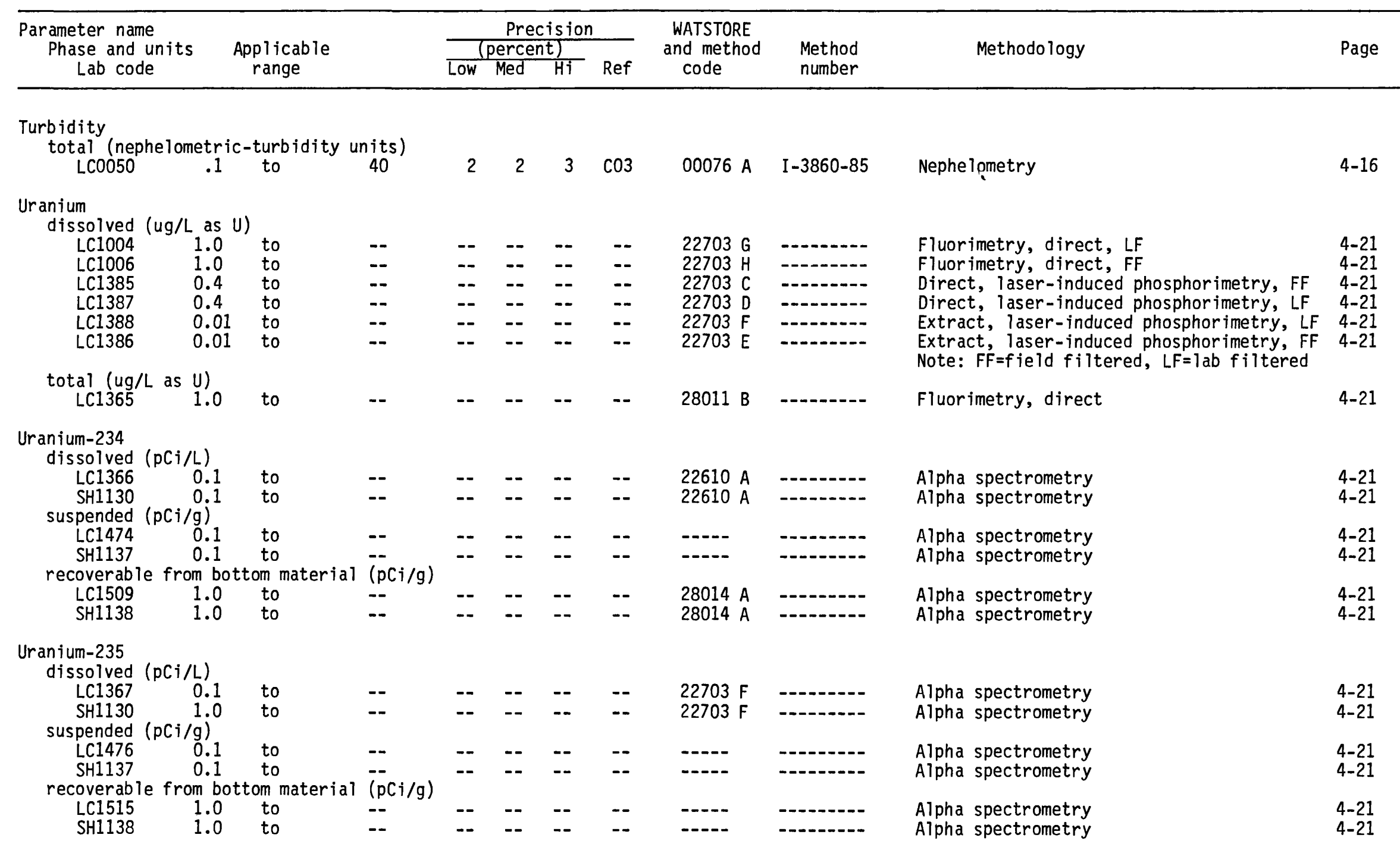


Table 5.2.--Index of analytical methodology for inorganic analyses---Continued

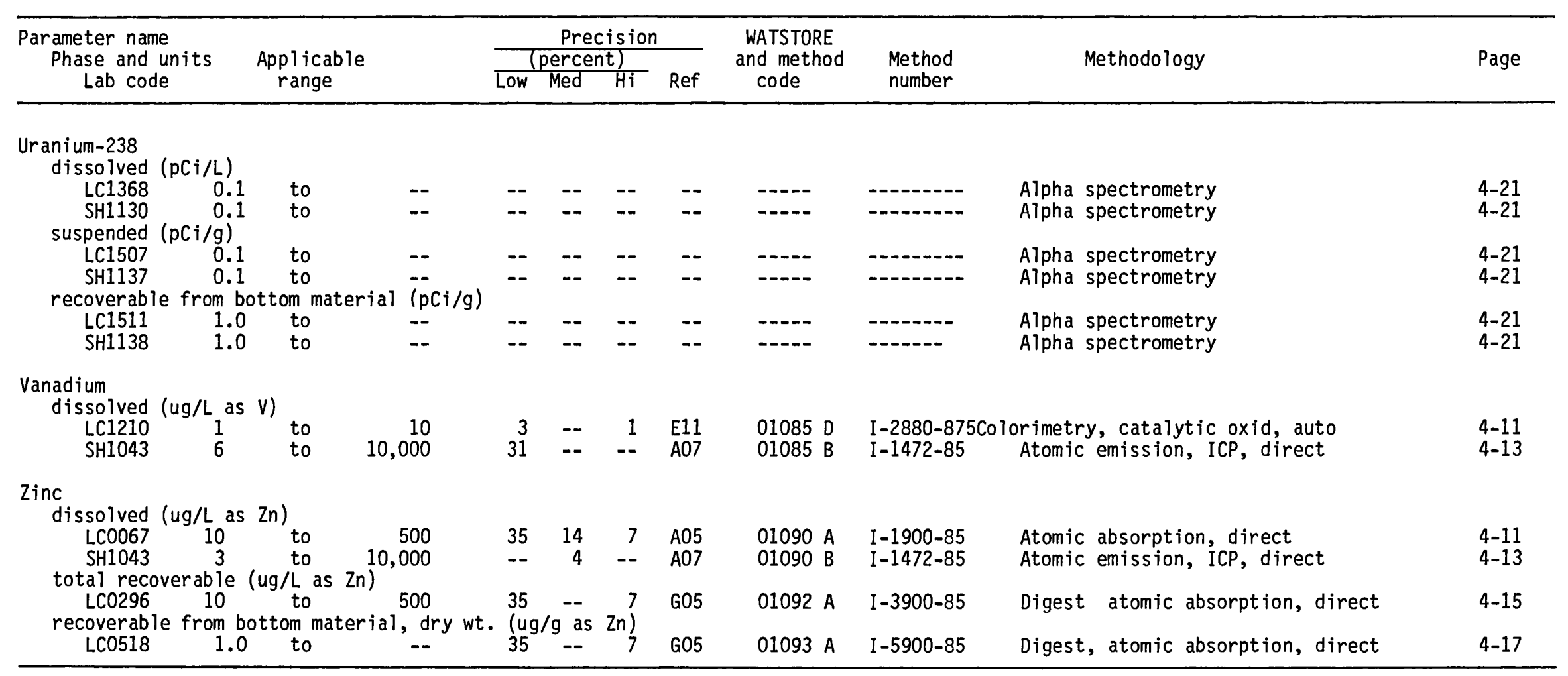




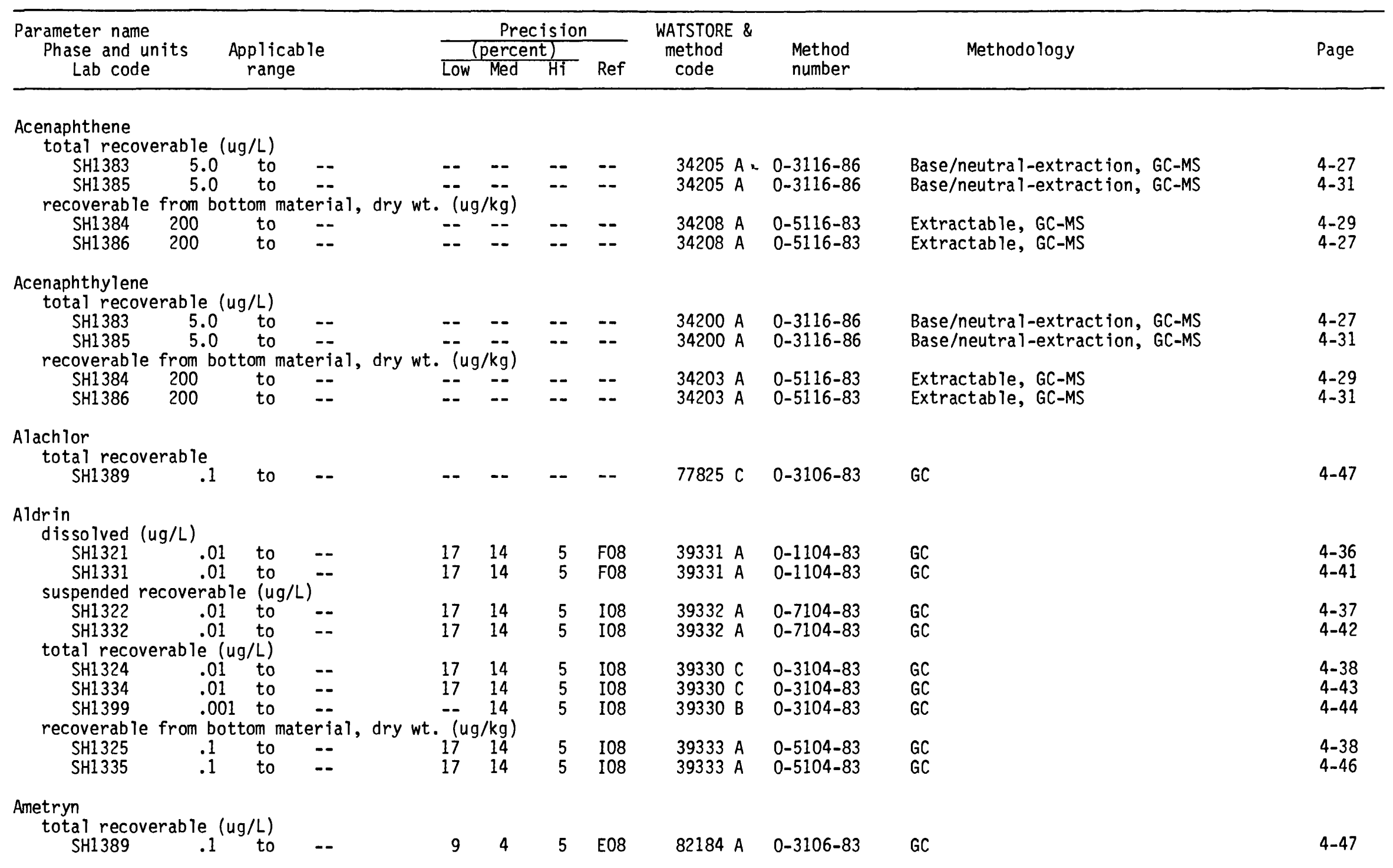




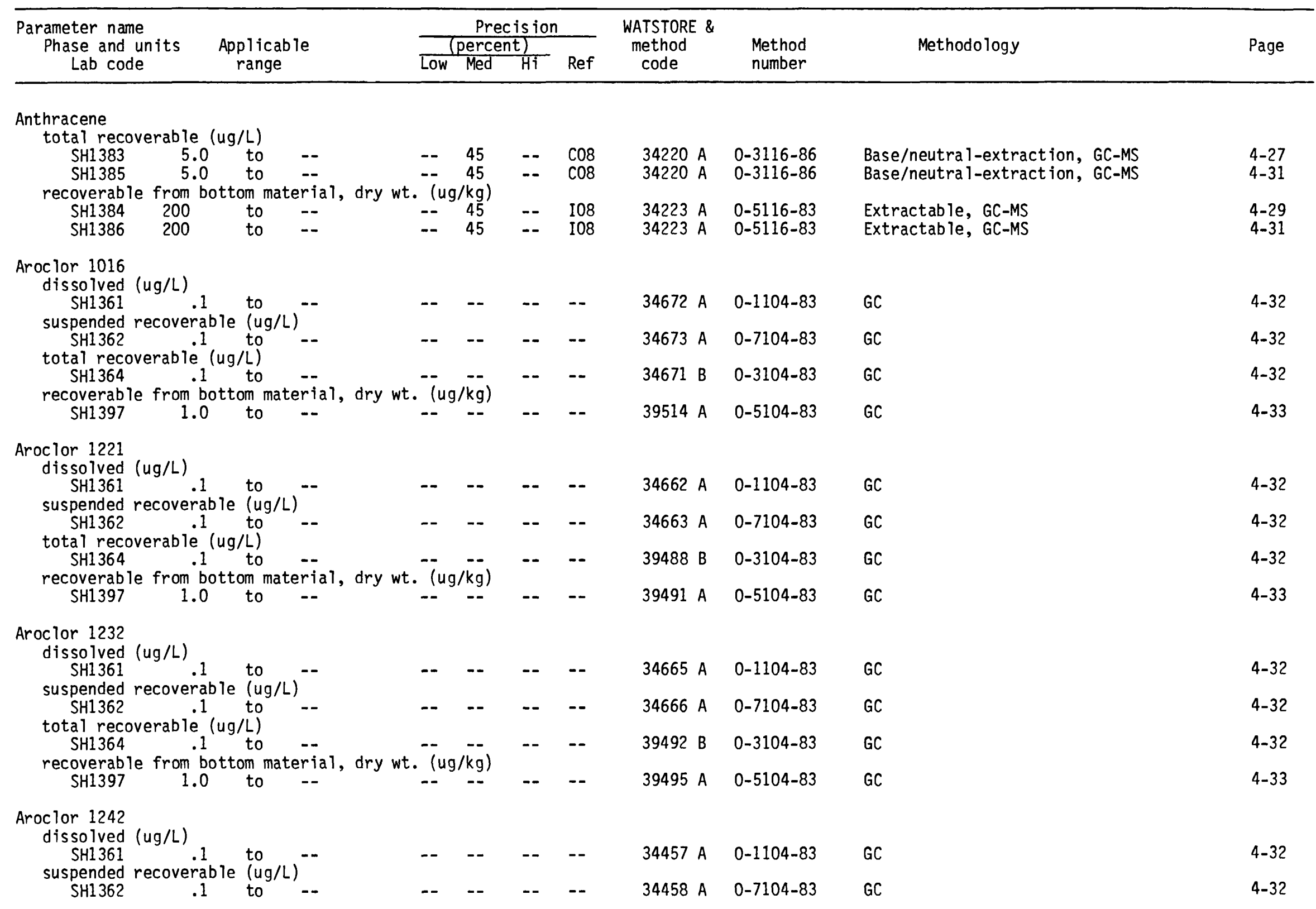


Table 5.3.1.--Index of analytical methodology for organic analyses--Continued

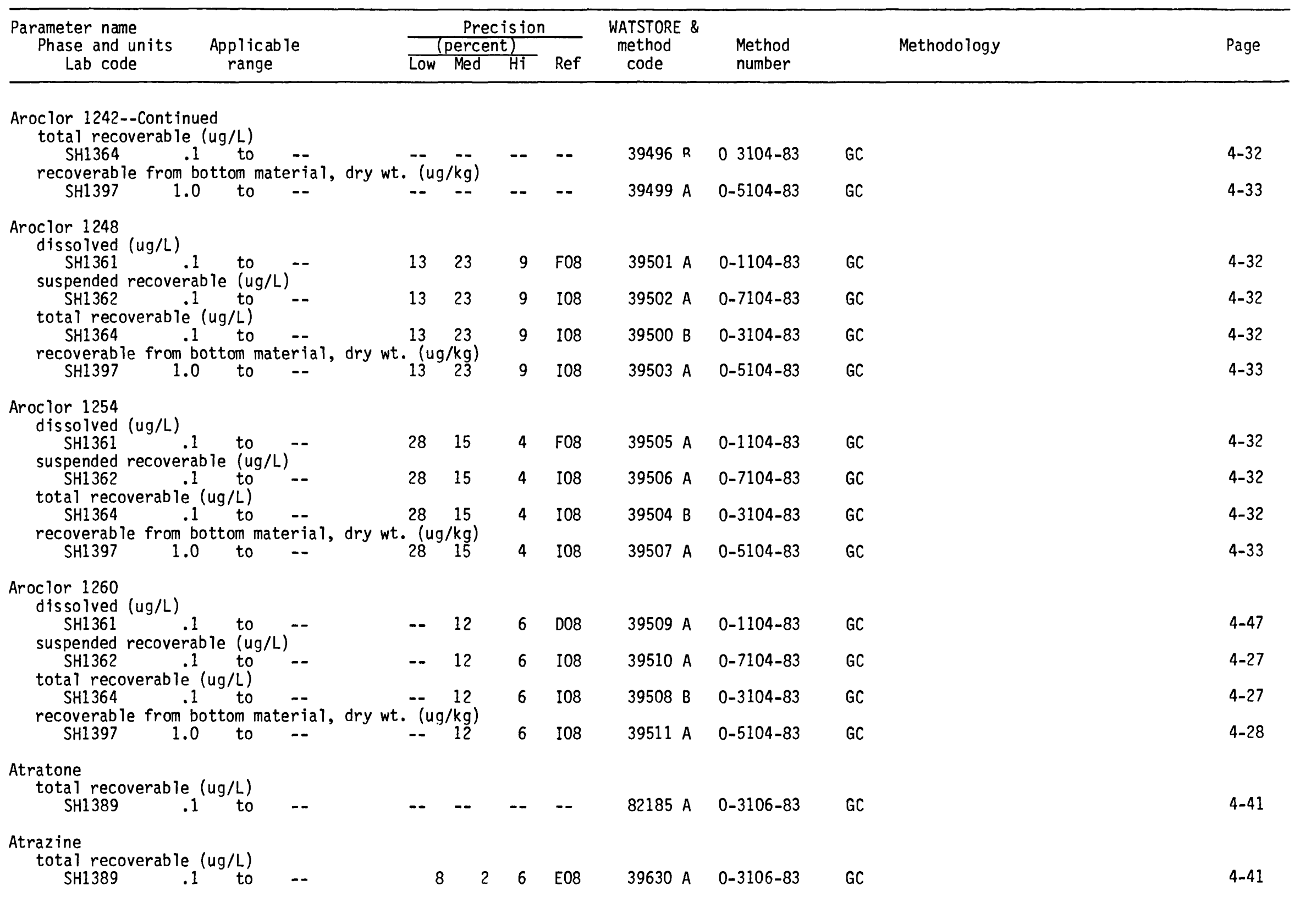




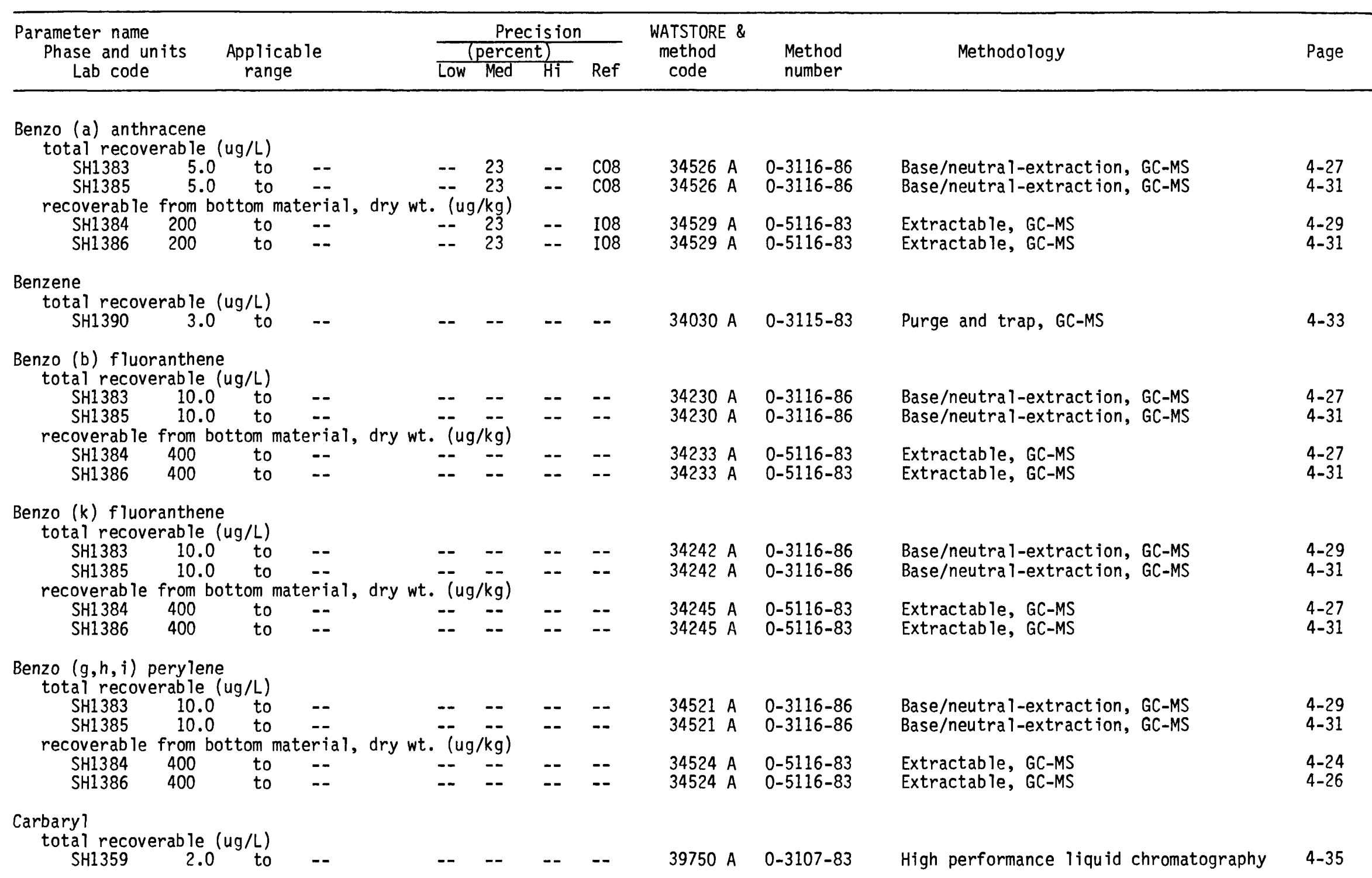




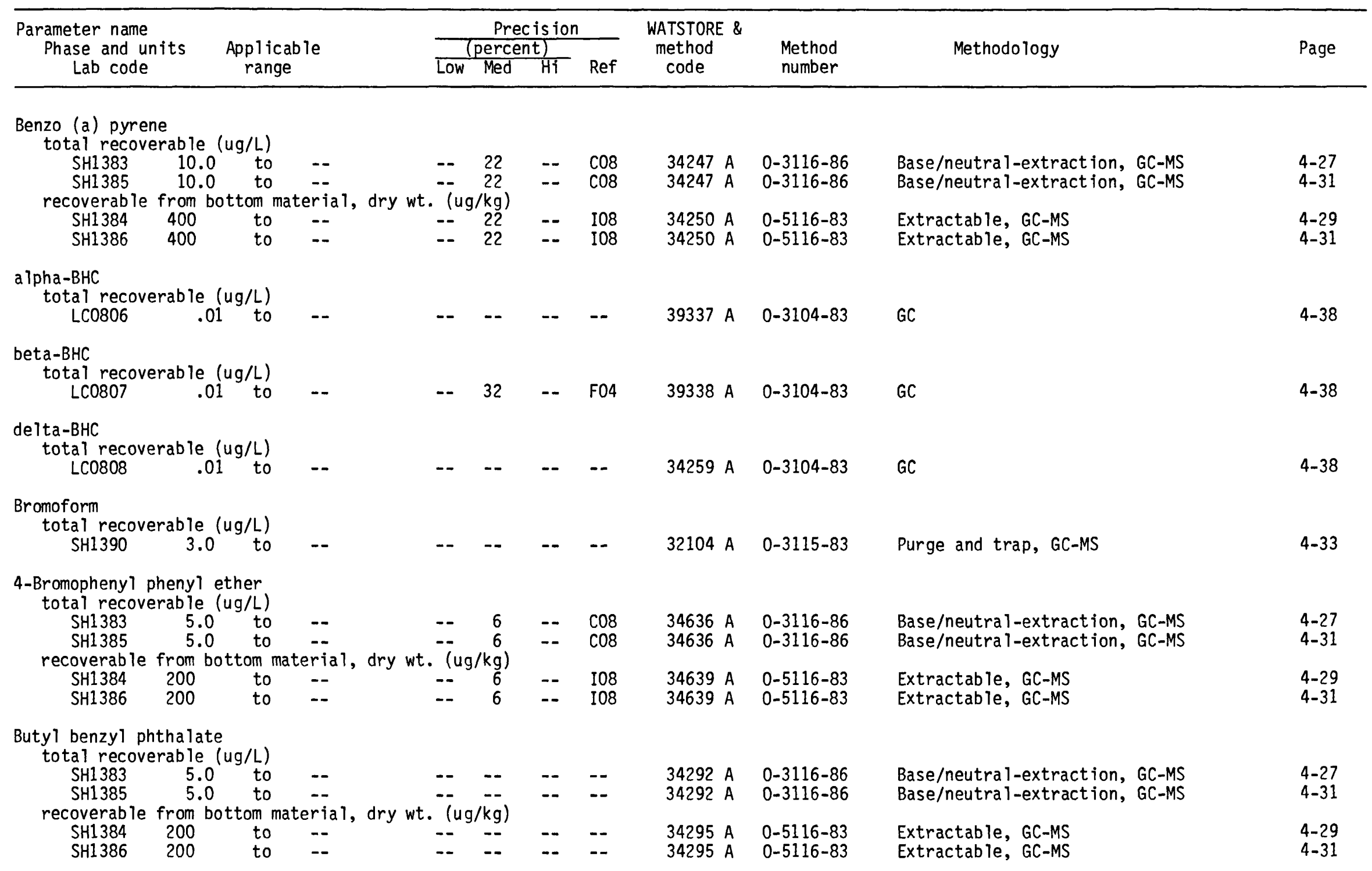




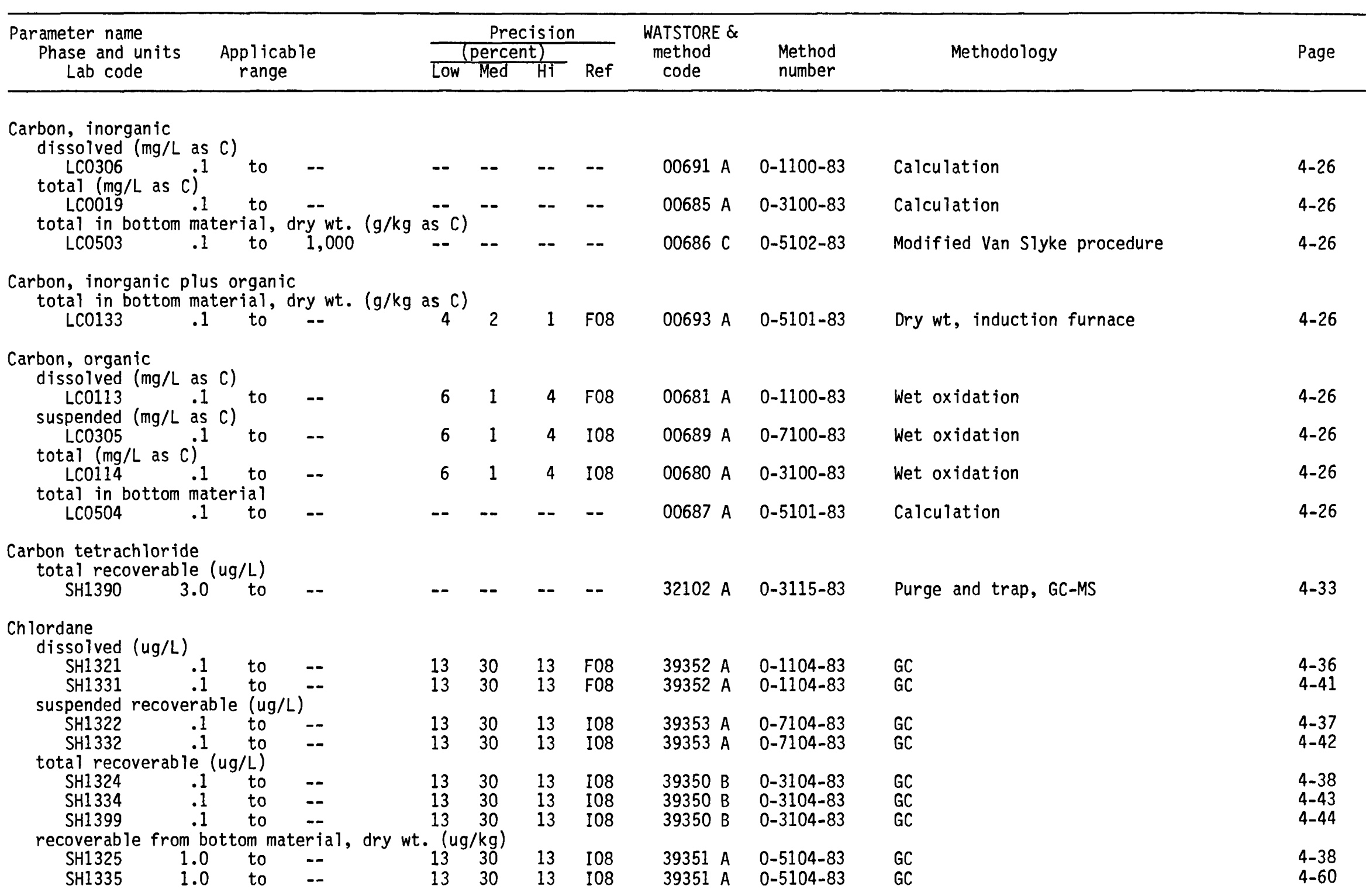


Table 5.3.1.---Index of analytical methodology for organic analyses--Continued

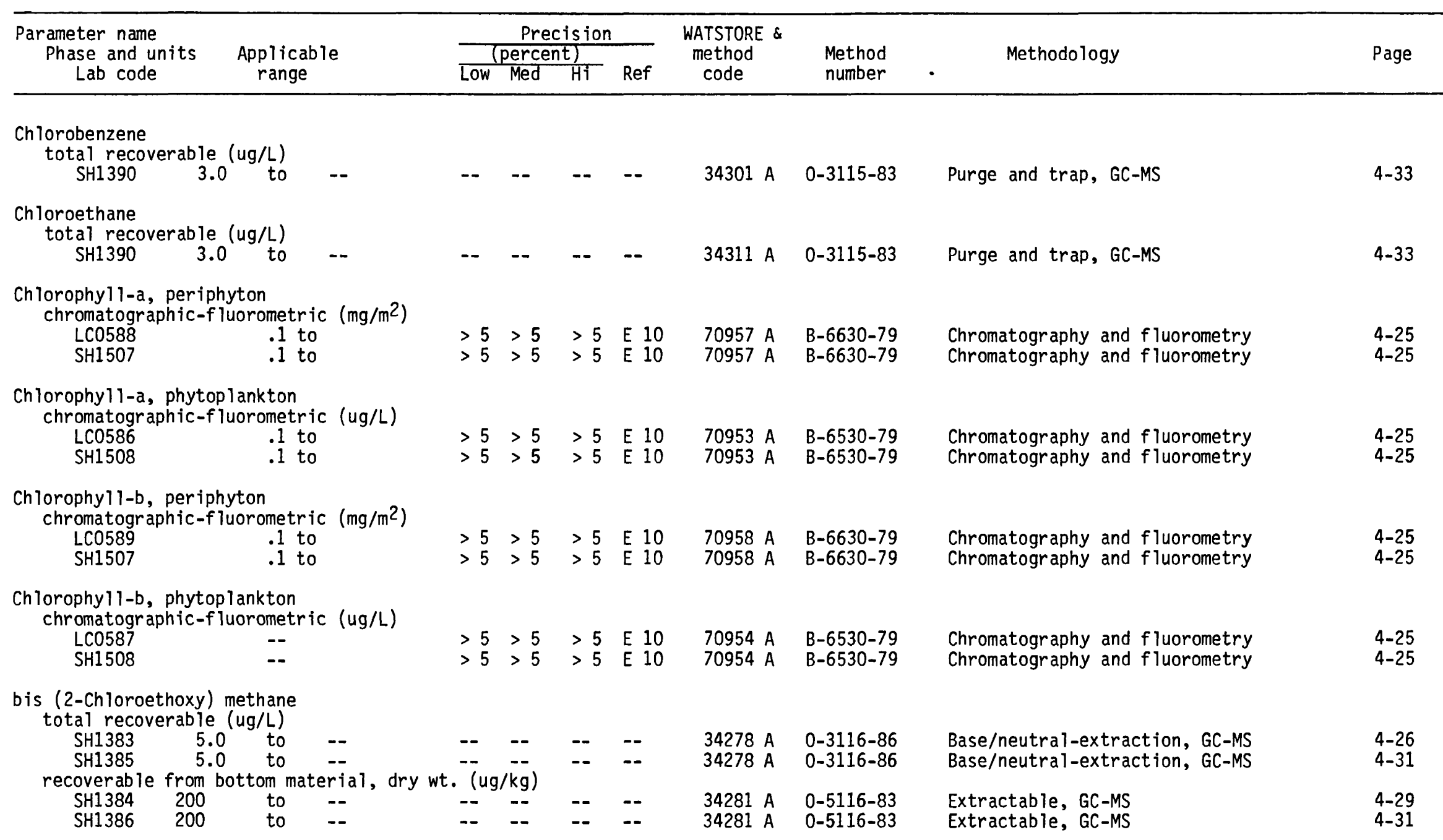




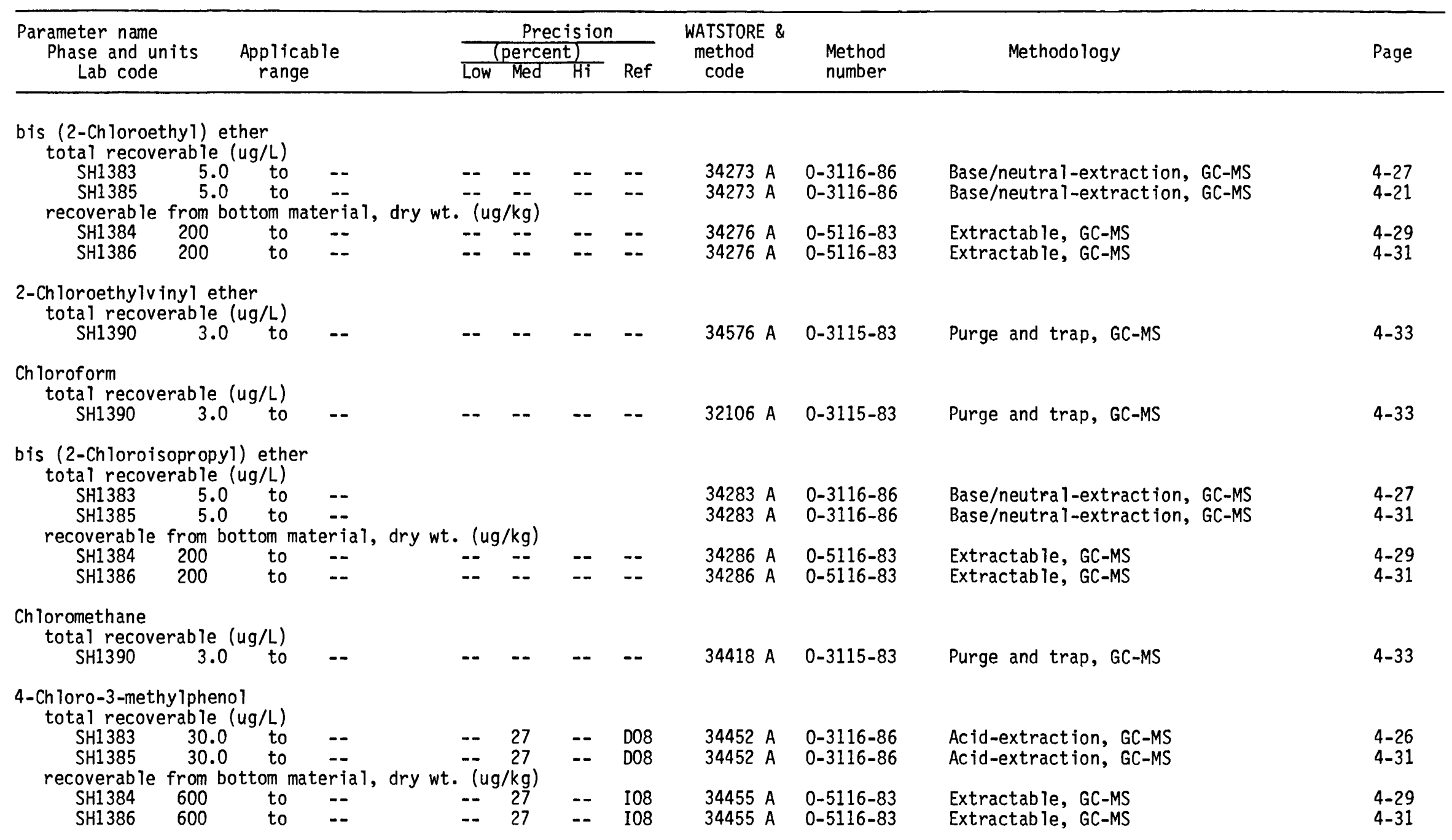


Table 5.3.1.--Index of analytical methodology for organic analyses--Continued

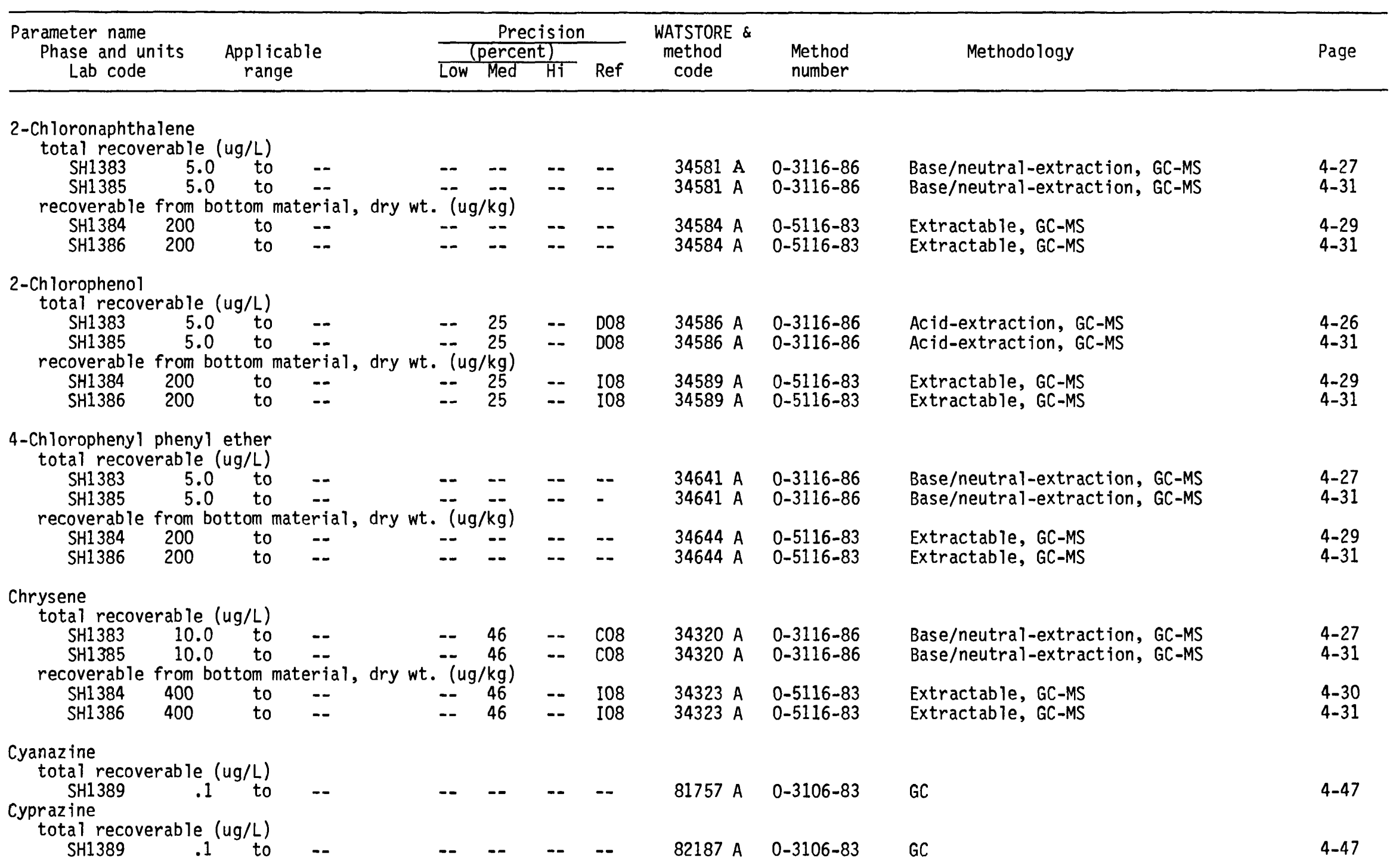




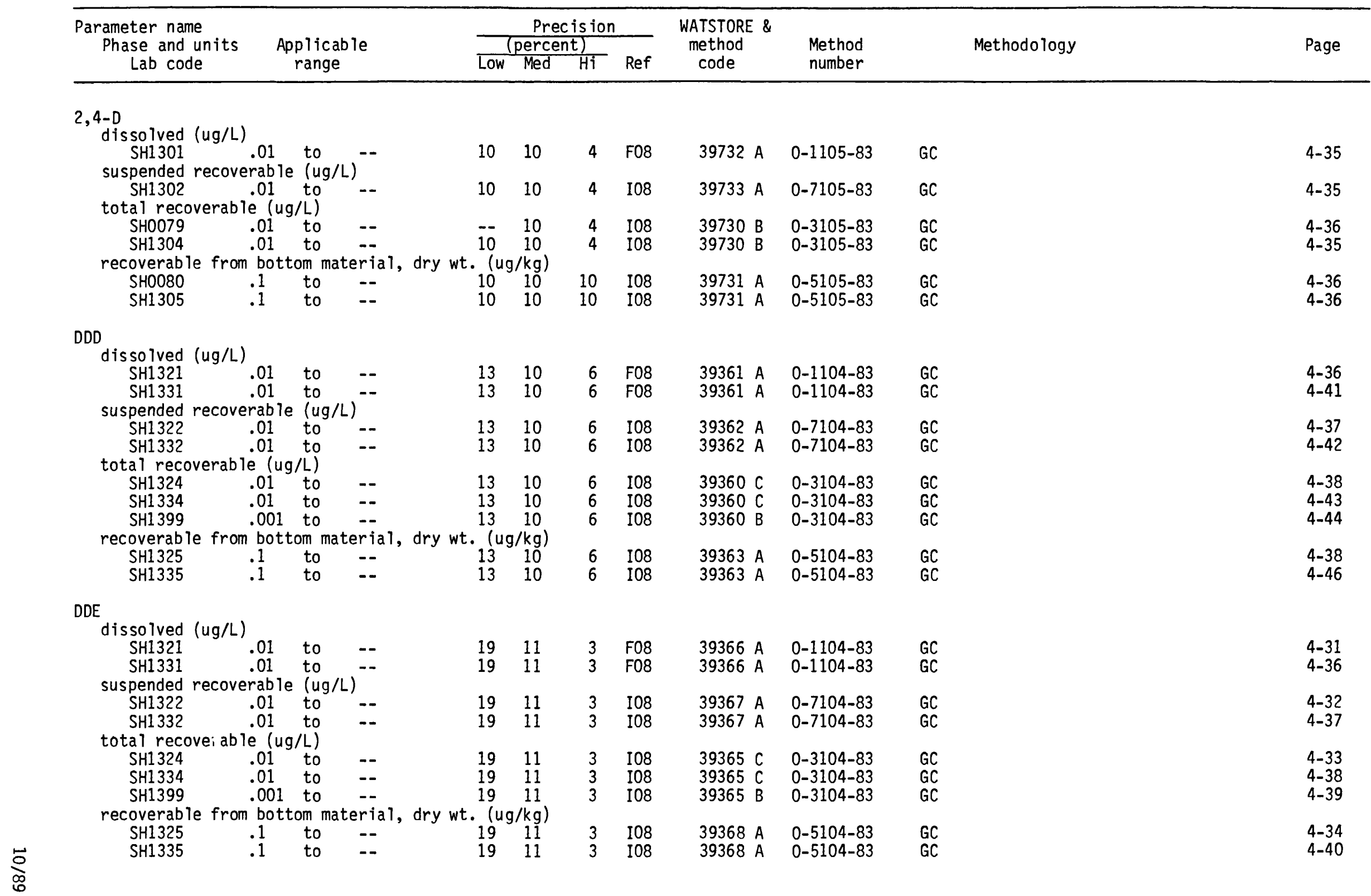


Table 5.3.1.--Index of analytical methodology for organic analyses--Continued

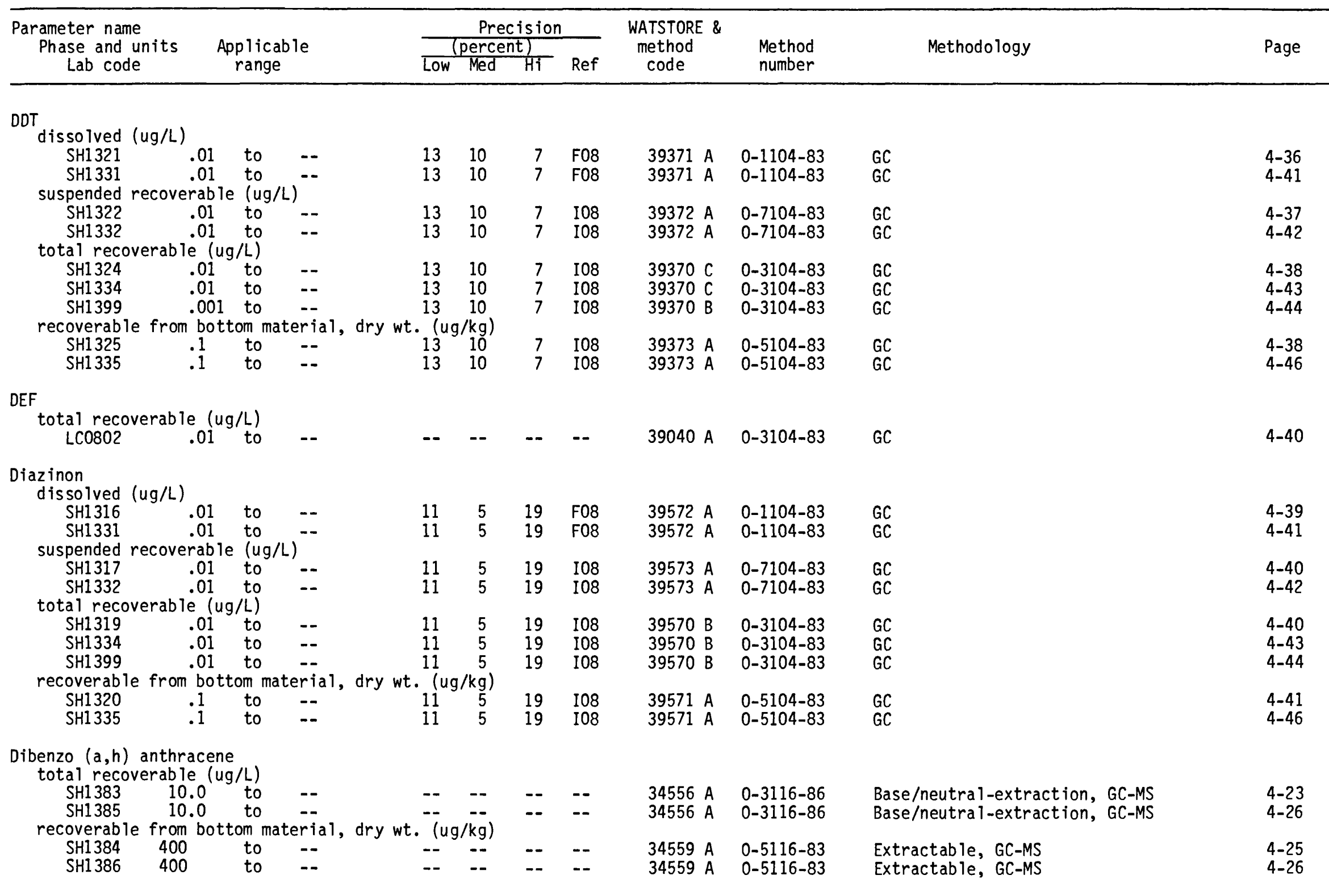




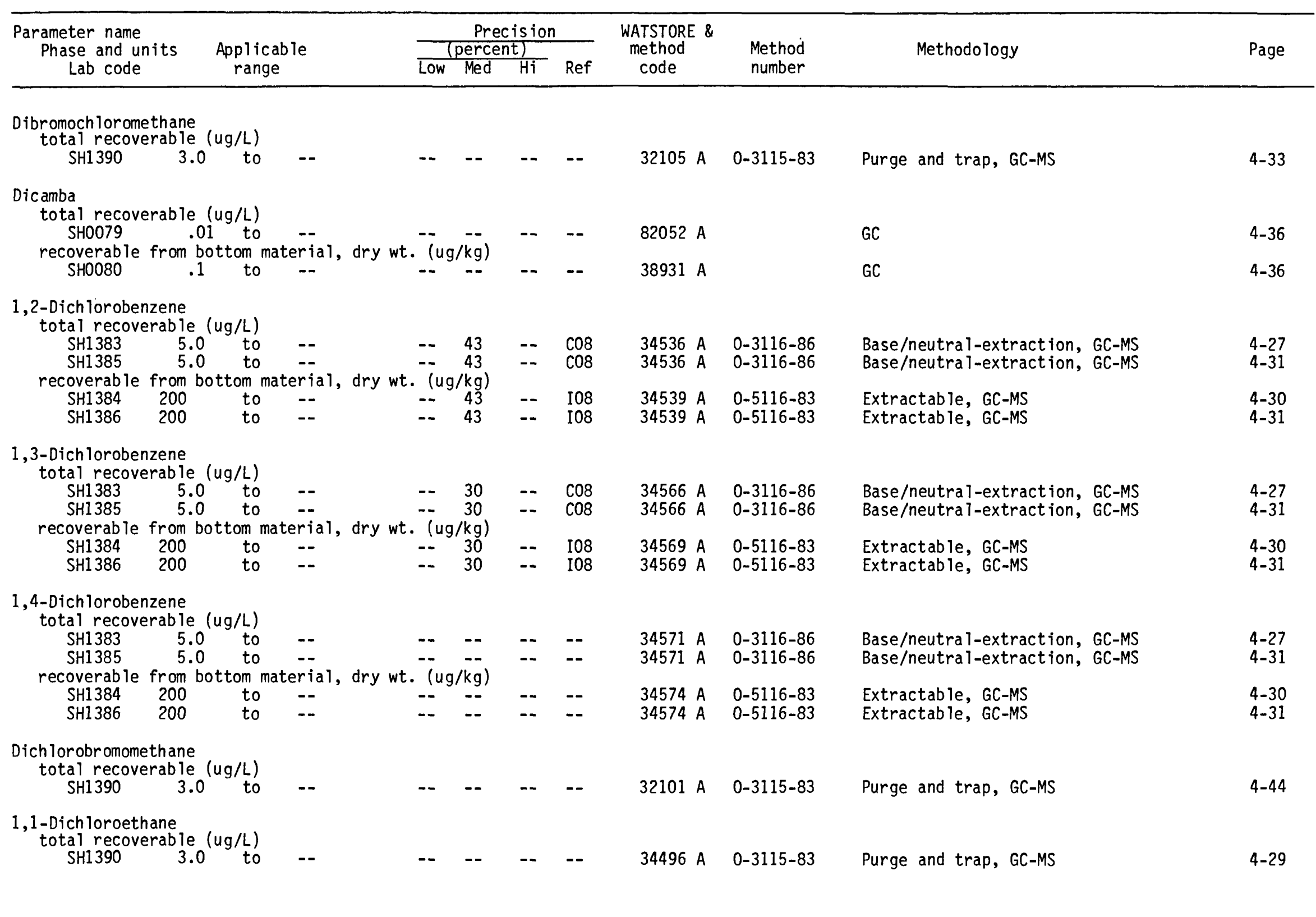




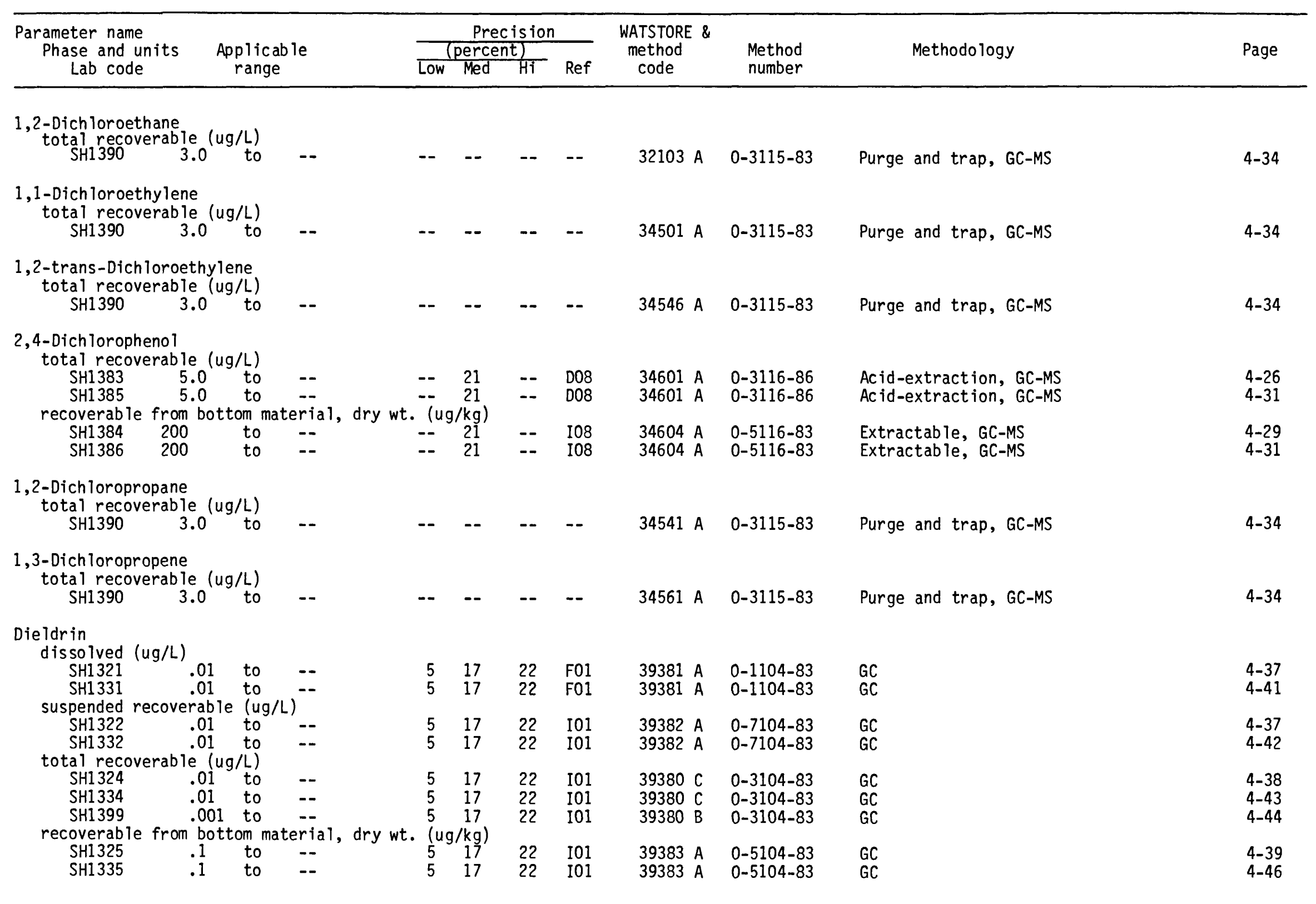




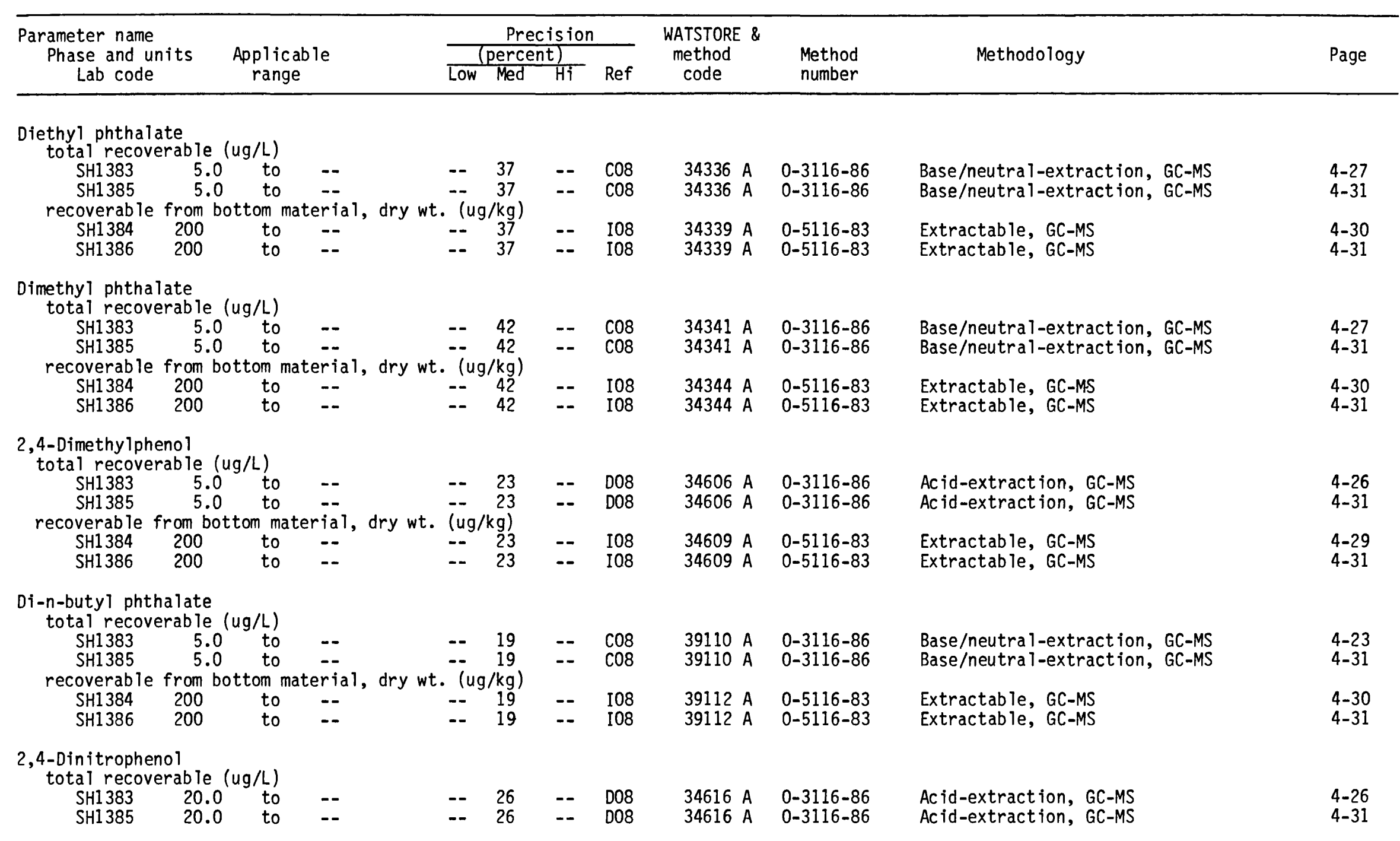




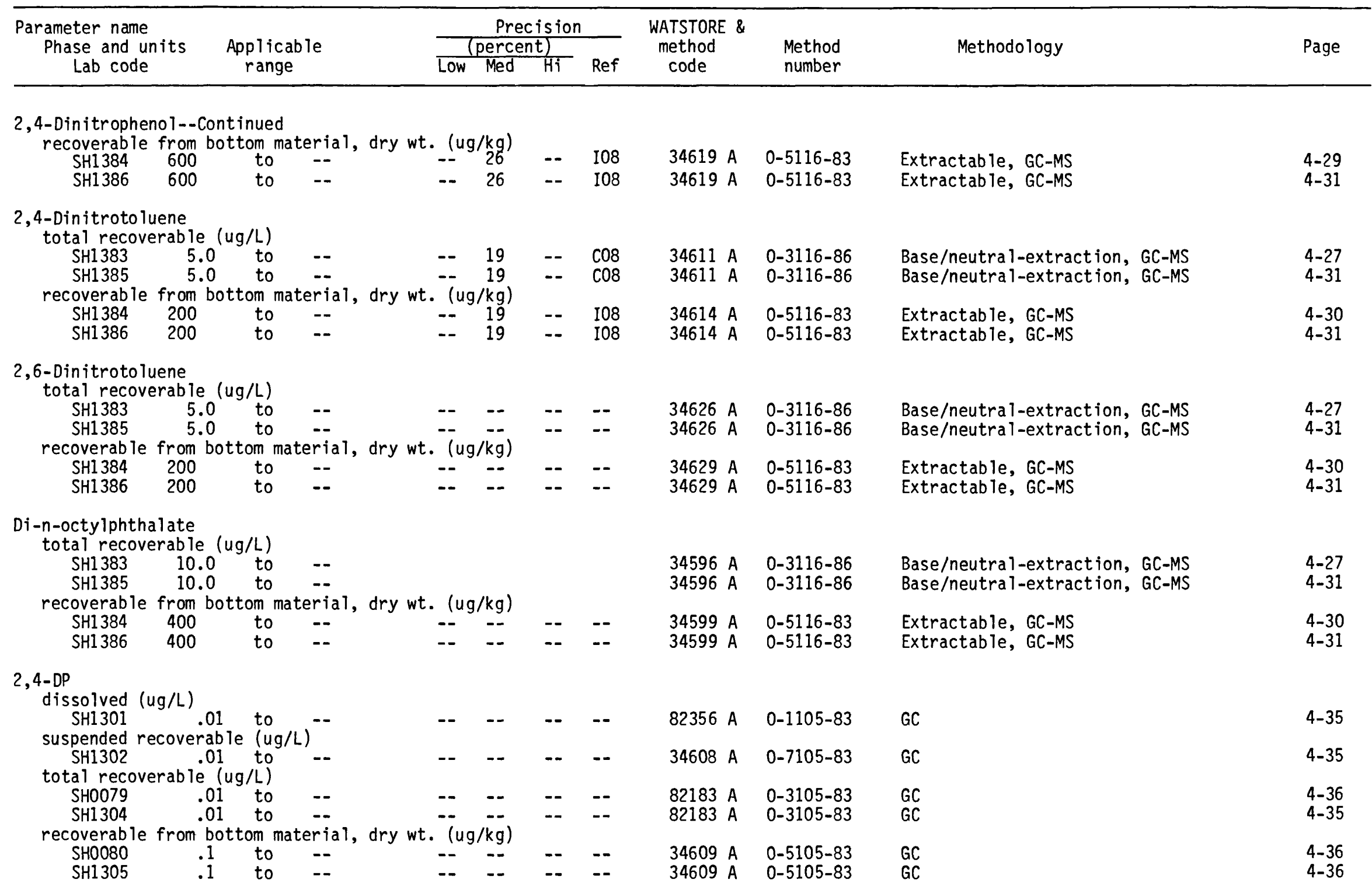




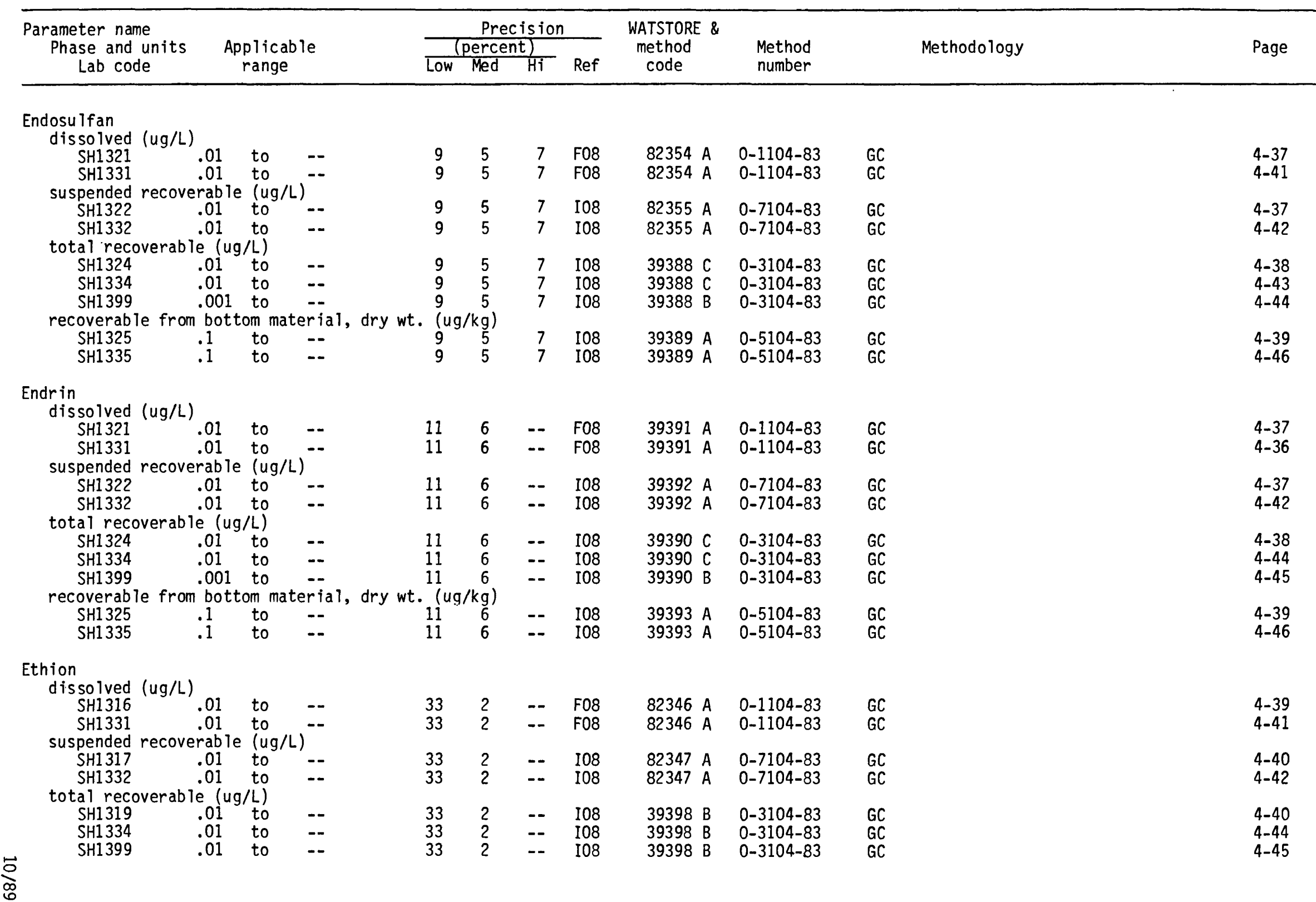


Table 5.3.1.--Index of analytical methodology for organic analyses--Continued

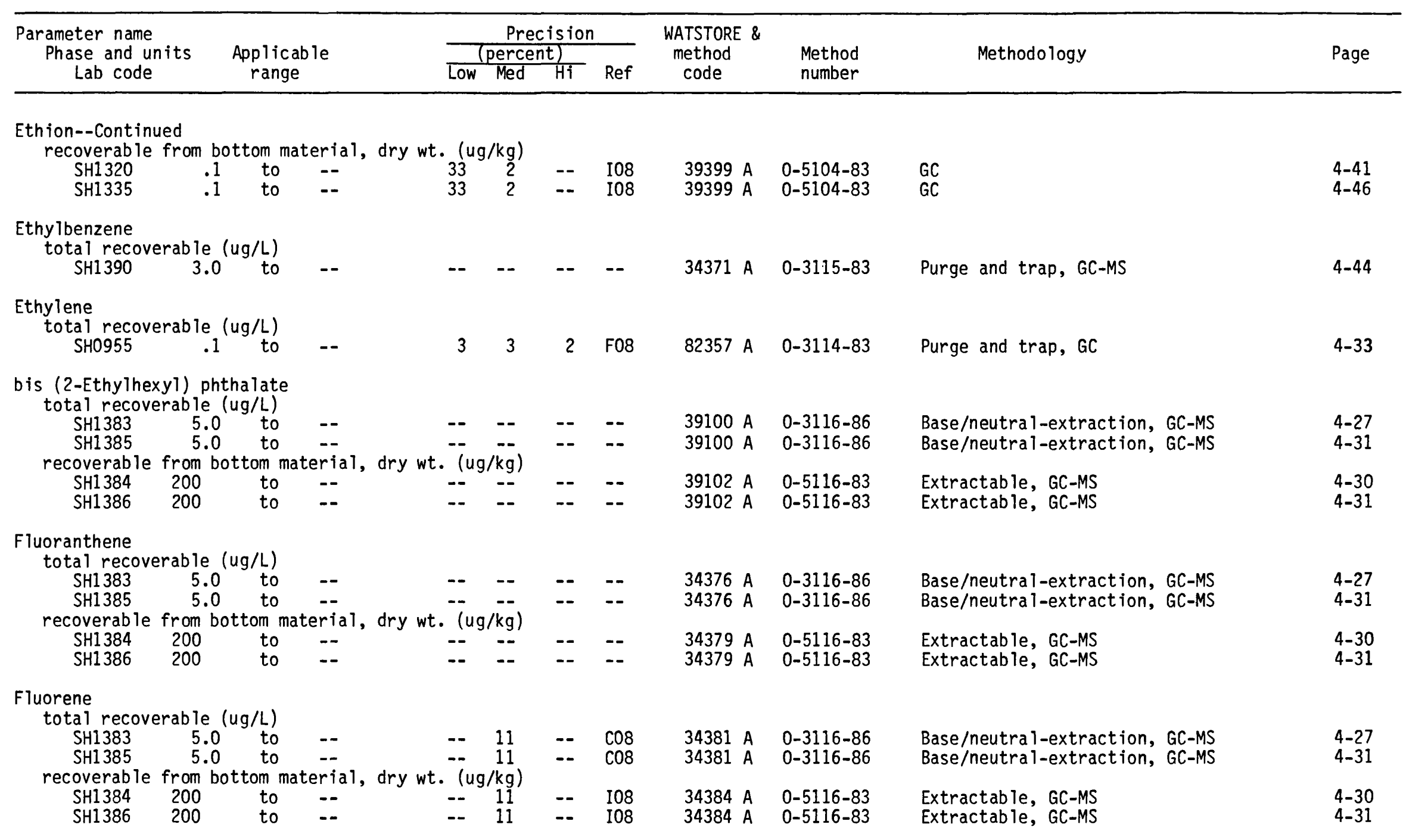




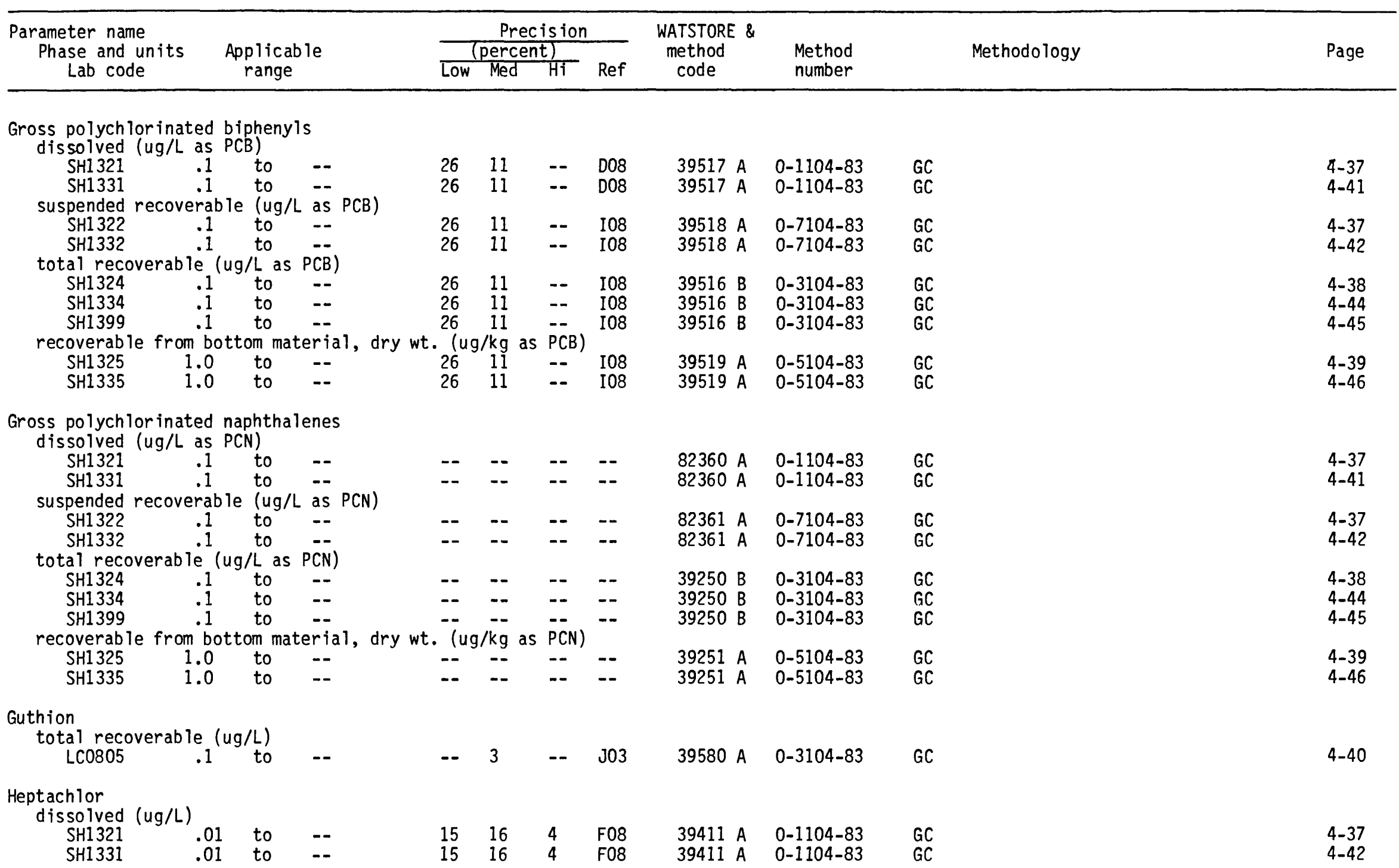




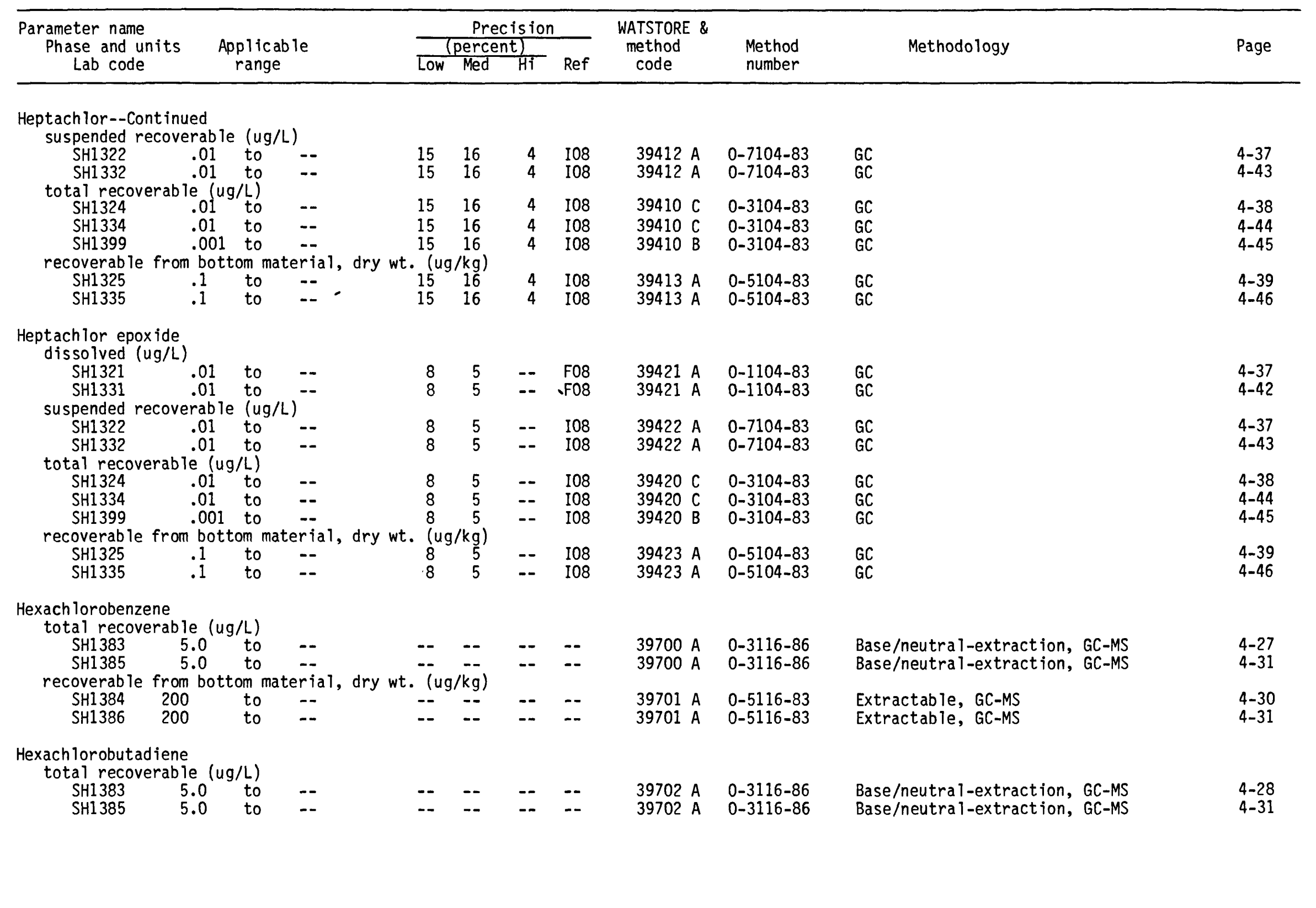




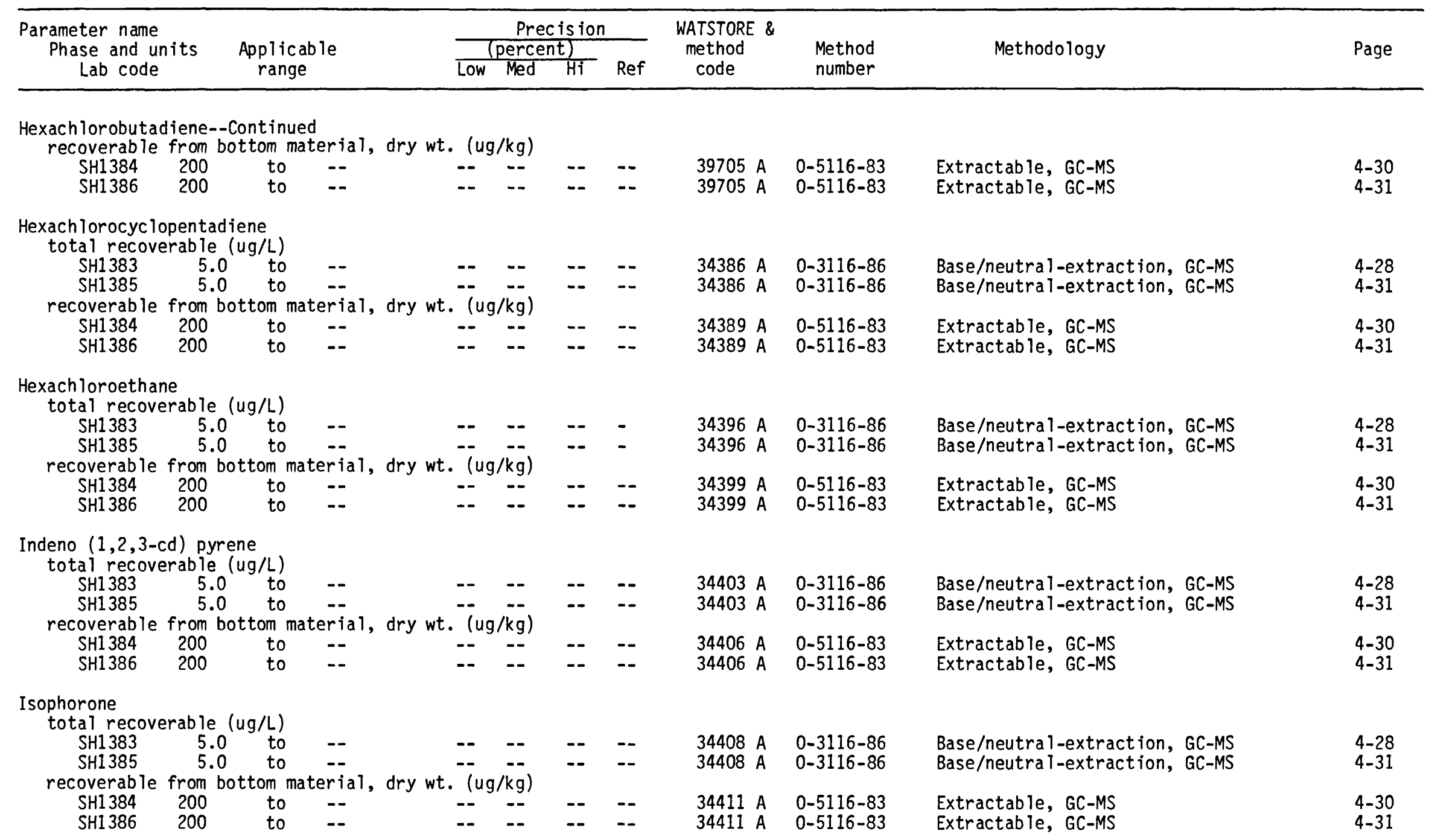




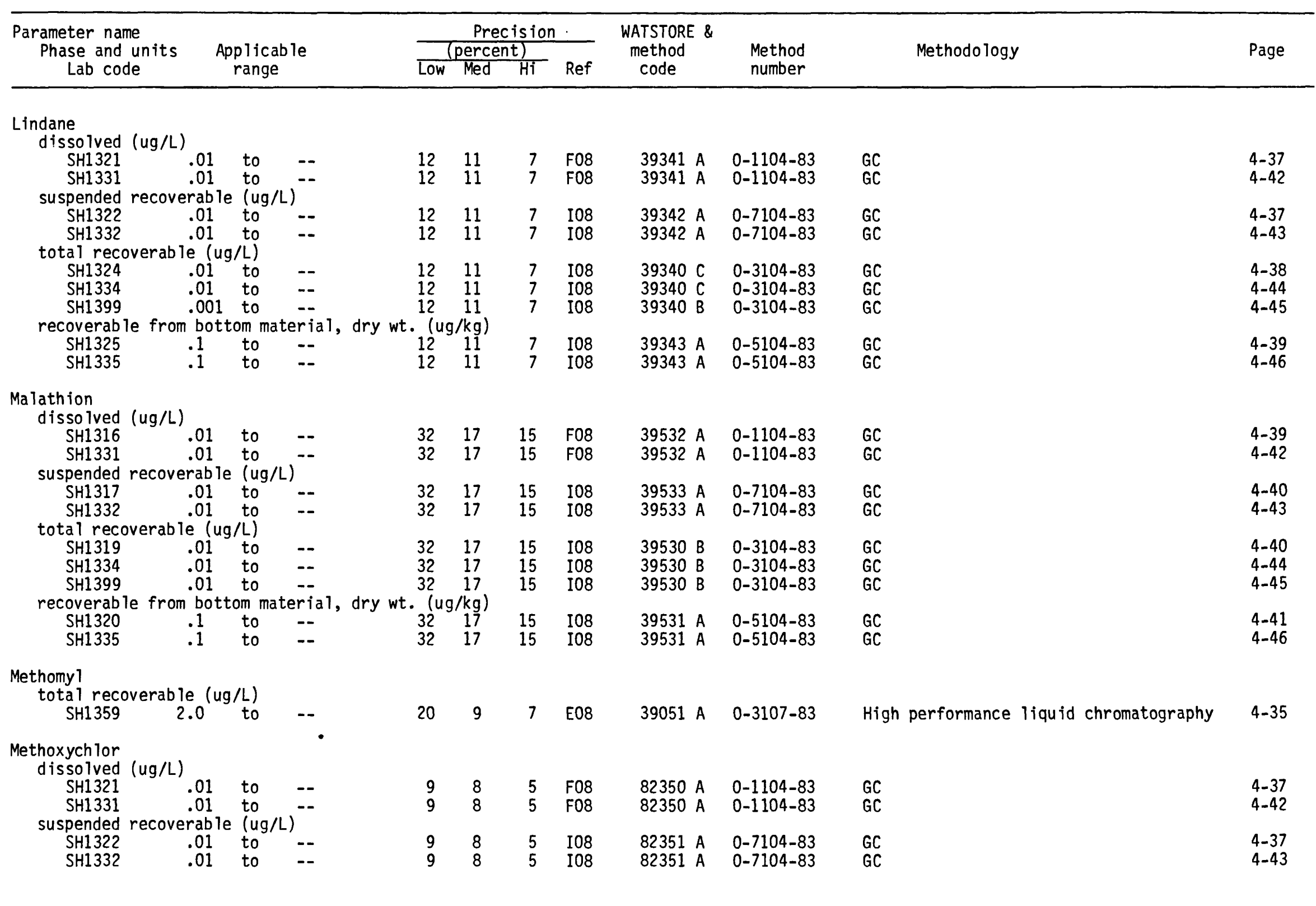




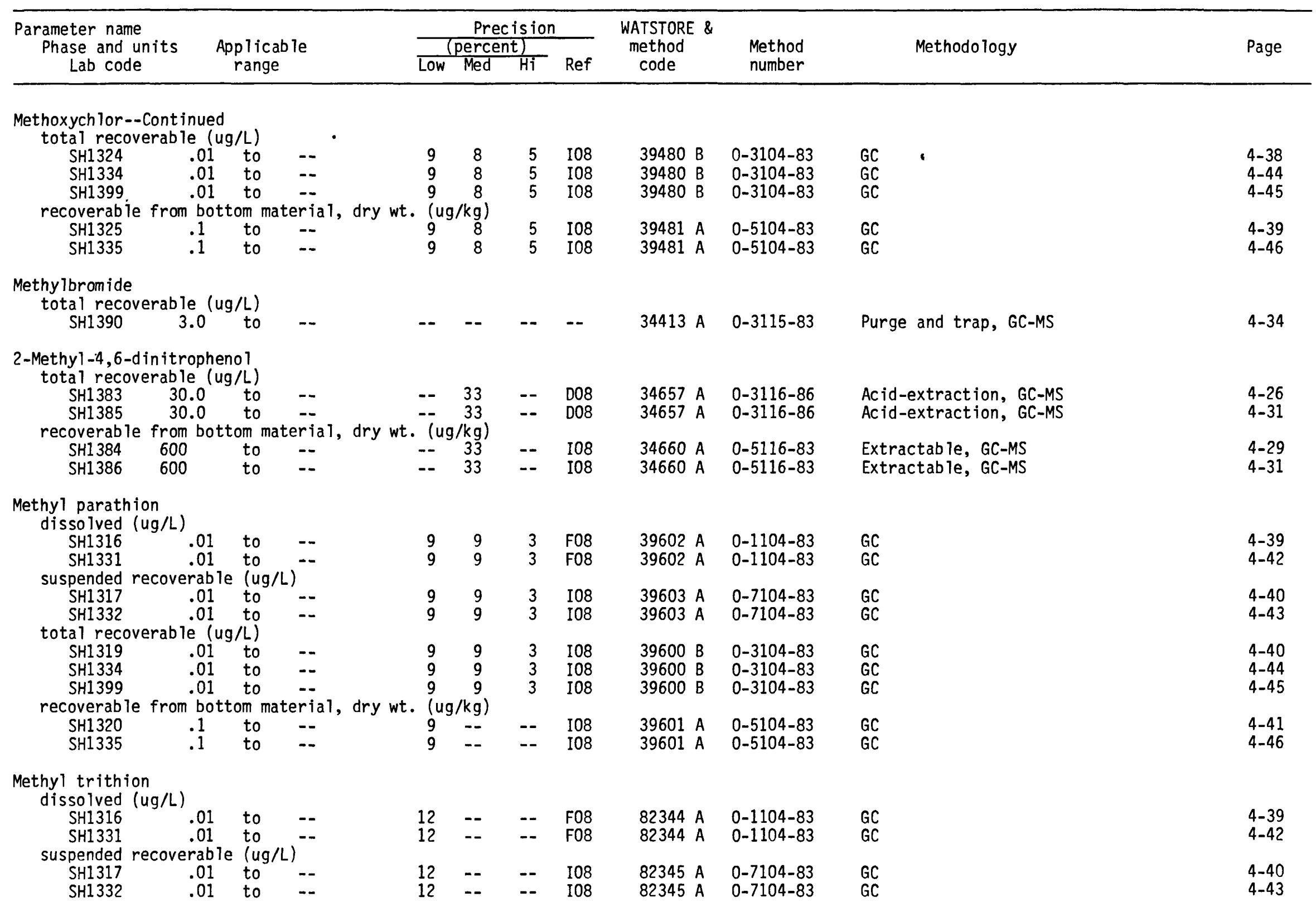




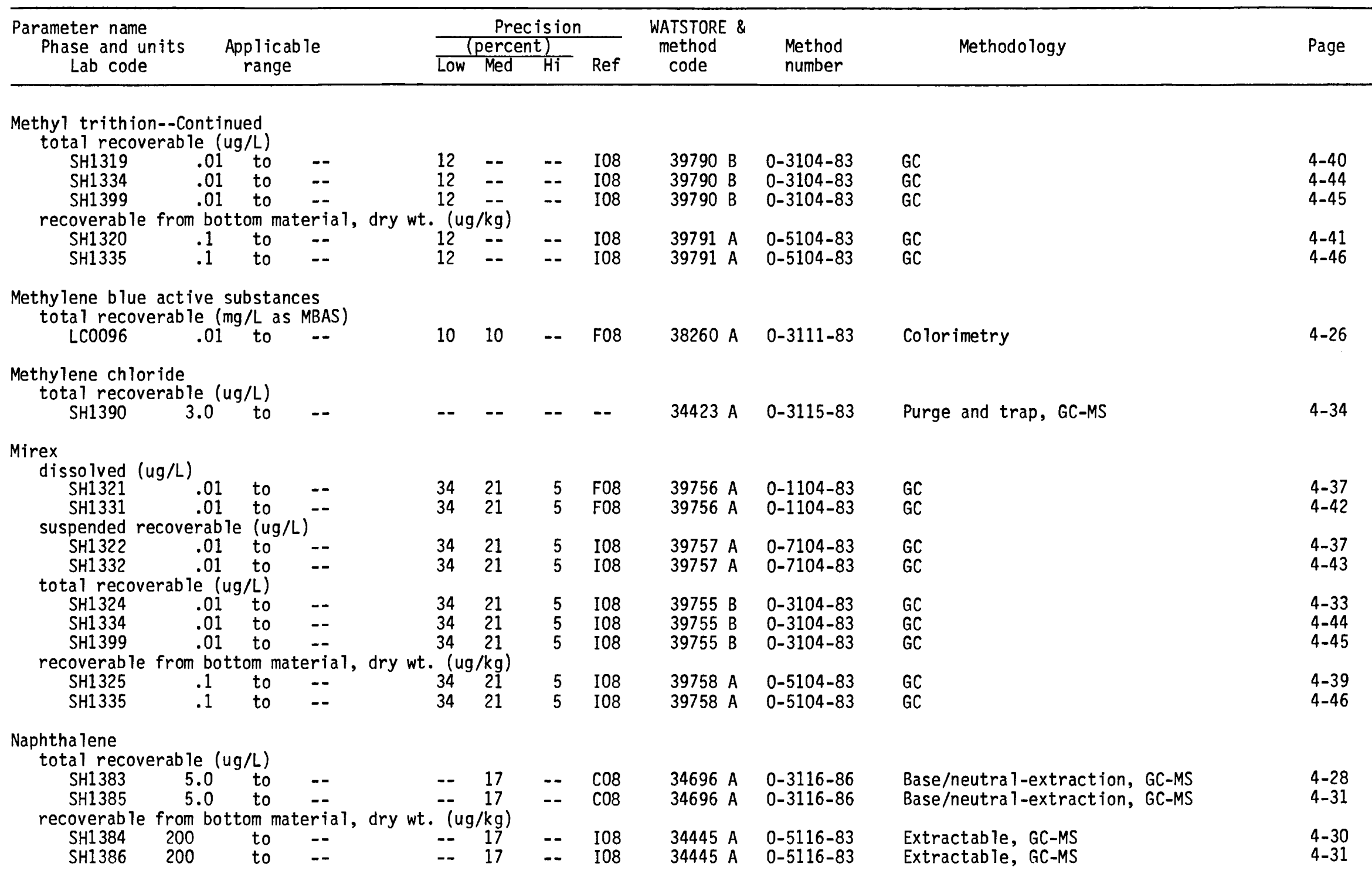




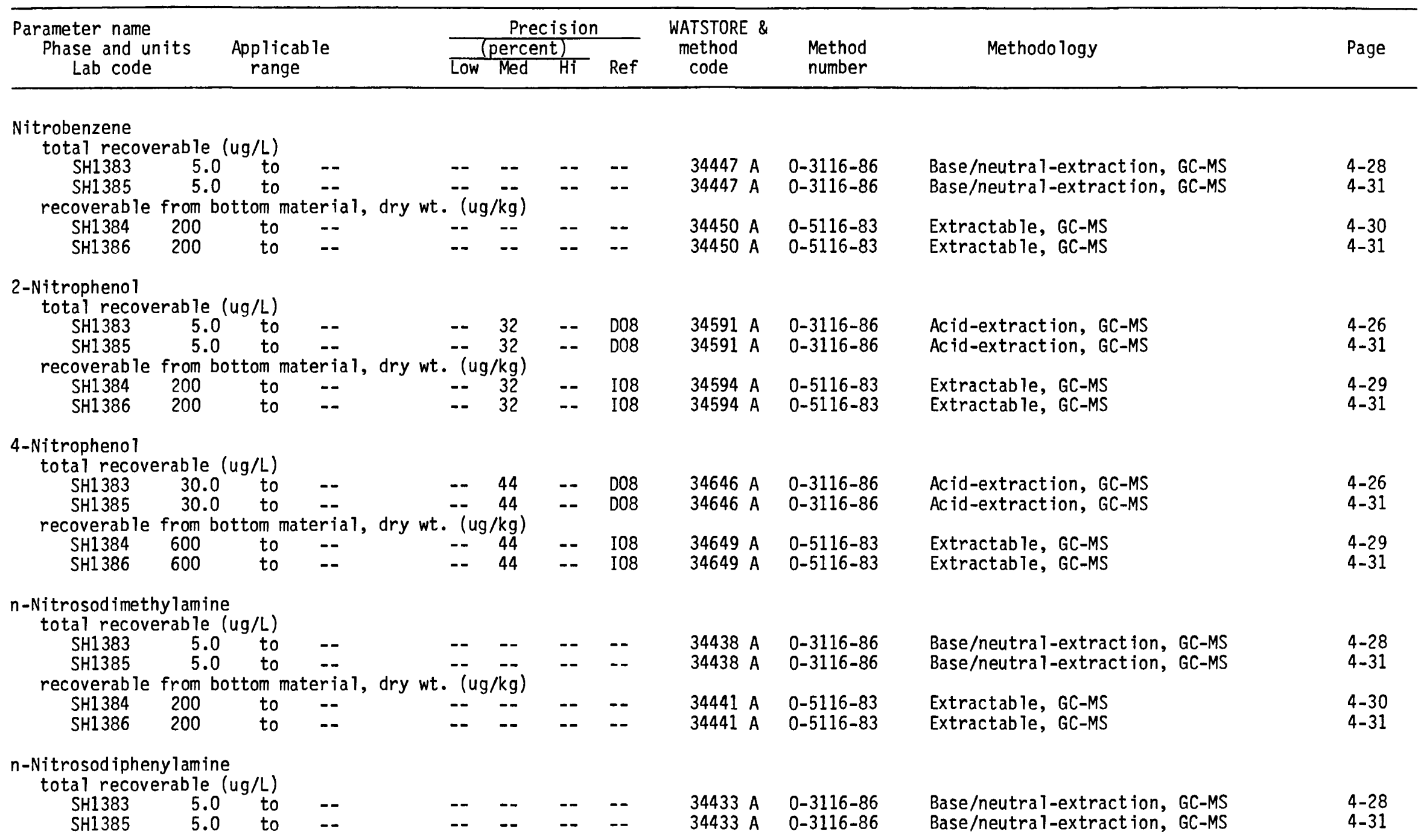


Table 5.3.1.--Index of analytical methodology for organic analyses--Continued

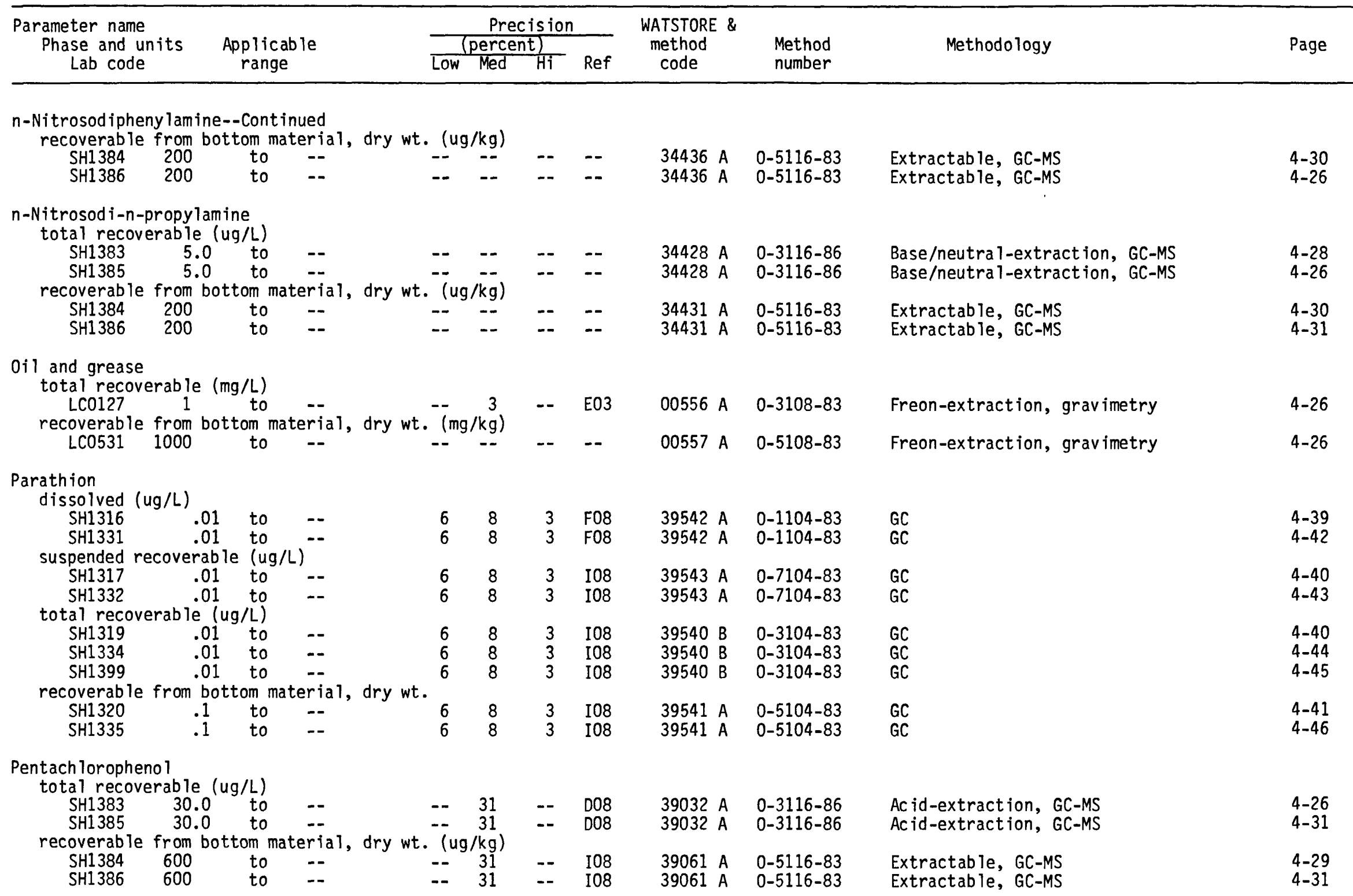


Table 5.3.1.--Index of analytical methodology for organic analyses--Continued

$\stackrel{1}{\infty}$

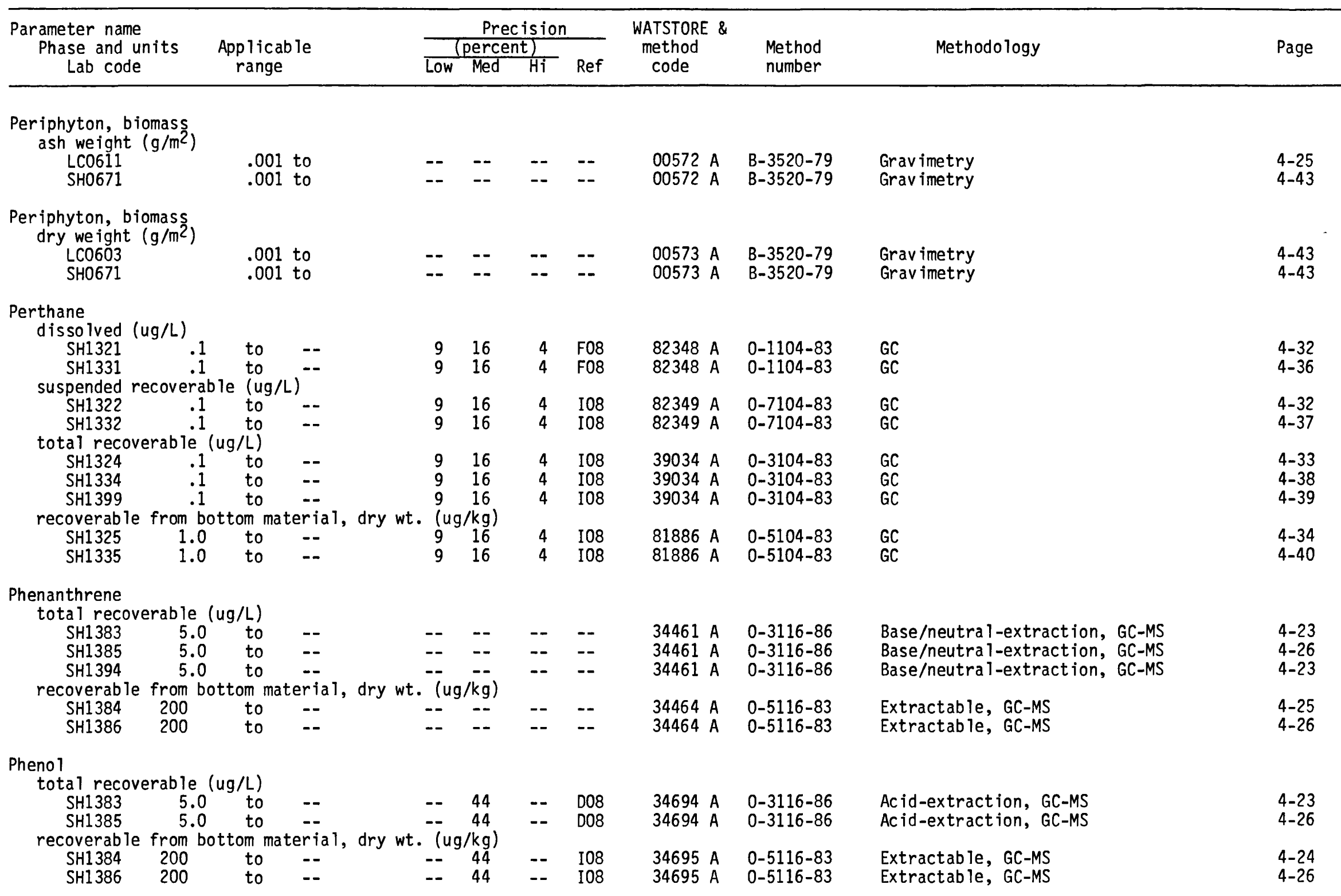


Table 5.3.1.--Index of analytical methodology for organic analyses--Continued

\begin{tabular}{|c|c|c|c|c|c|c|c|c|c|c|}
\hline \multirow{2}{*}{$\begin{array}{l}\text { Parameter name } \\
\text { Phase and units } \\
\text { Lab code }\end{array}$} & \multirow{2}{*}{\multicolumn{2}{|c|}{$\begin{array}{l}\text { Applicable } \\
\text { range }\end{array}$}} & \multicolumn{4}{|c|}{ Precision } & \multirow{2}{*}{$\begin{array}{l}\text { WATSTORE \& } \\
\text { method } \\
\text { code }\end{array}$} & \multirow[b]{2}{*}{$\begin{array}{l}\text { Method } \\
\text { number }\end{array}$} & \multirow[b]{2}{*}{ Methodology } & \multirow[b]{2}{*}{ Page } \\
\hline & & & $\frac{T}{\text { Low }}$ & $\frac{\text { percen }}{\text { Med }}$ & $\frac{\mathrm{Hi}}{\mathrm{Hi}}$ & Ref & & & & \\
\hline $\begin{array}{l}\text { Phytop lankton, biomas } \\
\text { ash weight }(\mathrm{mg} / \mathrm{L}) \\
\text { LCO621 } \\
\text { SH0666 }\end{array}$ & $\begin{array}{l}1 \text { to } \\
1 \text { to }\end{array}$ & & $=$ & $\begin{array}{l}-- \\
--\end{array}$ & $\begin{array}{l}-- \\
--\end{array}$ & -- & $\begin{array}{l}81353 \mathrm{~A} \\
81353 \mathrm{~A}\end{array}$ & $\begin{array}{l}\text { B-6560-79 } \\
\text { B-6560-79 }\end{array}$ & $\begin{array}{l}\text { Gravimetry } \\
\text { Gravimetry }\end{array}$ & $\begin{array}{l}4-25 \\
4-25\end{array}$ \\
\hline $\begin{array}{l}\text { Phytoplankton, biomas } \\
\text { dry we ight (mg/L) } \\
\text { LC0620 } \\
\text { SH0666 }\end{array}$ & $\begin{array}{l}1 \text { to } \\
1 \text { to }\end{array}$ & & $\begin{array}{l}-- \\
--\end{array}$ & $\begin{array}{l}-- \\
--\end{array}$ & -- & $\begin{array}{l}-- \\
--\end{array}$ & $\begin{array}{l}81354 \mathrm{~A} \\
81354 \mathrm{~A}\end{array}$ & $\begin{array}{l}\text { B-6560-79 } \\
\text { B-6560-79 }\end{array}$ & $\begin{array}{l}\text { Gravimetry } \\
\text { Gravimetry }\end{array}$ & $\begin{array}{l}4-25 \\
4-25\end{array}$ \\
\hline $\begin{array}{l}\text { Picloram } \\
\text { total recoverable } \\
\text { SH0079 } \\
\text { recoverable from } \\
\text { SH0080 }\end{array}$ & $\begin{array}{l}(\mathrm{ug} / \mathrm{L}) \\
1 \text { to } \\
\text { ottom ma } \\
\text { to }\end{array}$ & $\begin{array}{l}-- \\
\text { terial, dry wt. } \\
--\end{array}$ & lug/ & $\begin{array}{l}-- \\
1 / \mathrm{kg}) \\
--\end{array}$ & -- & -- & $39720 \mathrm{~A}$ & $0-3105-83$ & GC & $4-36$ \\
\hline $\begin{array}{l}\text { Prometon } \\
\text { total recoverable } \\
\text { SH1389 }\end{array}$ & $\begin{array}{r}\text { (ug/L) } \\
\text { to }\end{array}$ & -- & 6 & 2 & 5 & E08 & $39056 \mathrm{~A}$ & $0-3106-83$ & GC & $4-47$ \\
\hline $\begin{array}{l}\text { Prometryn } \\
\text { total recoverable } \\
\text { SH1389 }\end{array}$ & $\begin{array}{r}\text { (ug/L) } \\
\text { to }\end{array}$ & -- & 5 & 2 & 5 & E08 & 39057 A & $0-3106-83$ & GC & $4-47$ \\
\hline $\begin{array}{l}\text { Propane } \\
\text { total recoverab le } \\
\quad \text { SH0955 }\end{array}$ & $\begin{array}{r}\text { (ug/L) } \\
\text { to }\end{array}$ & -- & 4 & 2 & 2 & F08 & 82358 A & $0-3114-83$ & Purge and trap, GC & $4-23$ \\
\hline $\begin{array}{l}\text { Propazine } \\
\text { total recoverable } \\
\qquad \text { SH1389 }\end{array}$ & $\begin{array}{r}\text { (ug/L) } \\
\text { to }\end{array}$ & -- & 6 & 2 & 5 & E08 & 39024 A & $0-3106-83$ & GC & $4-47$ \\
\hline
\end{tabular}




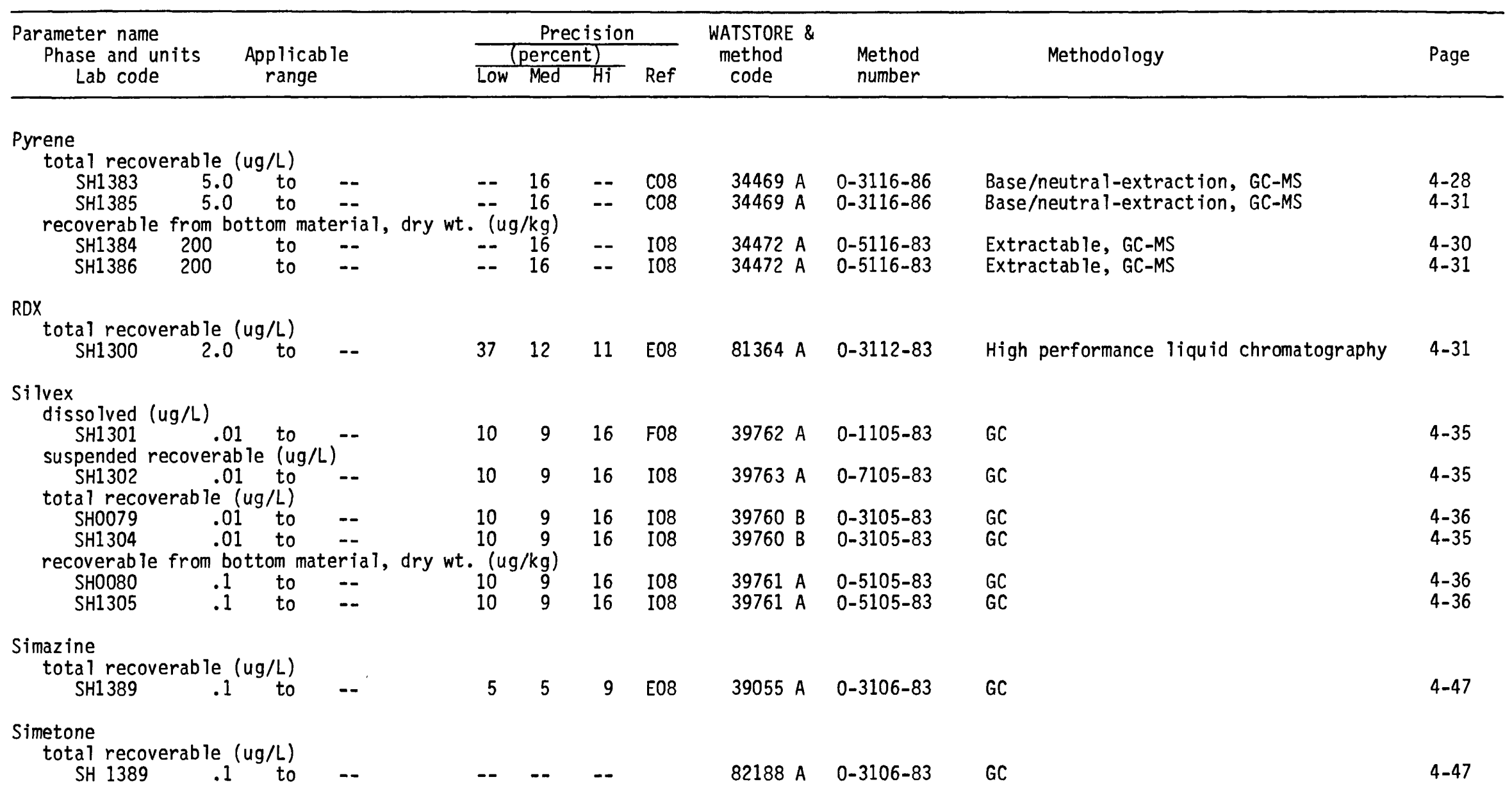




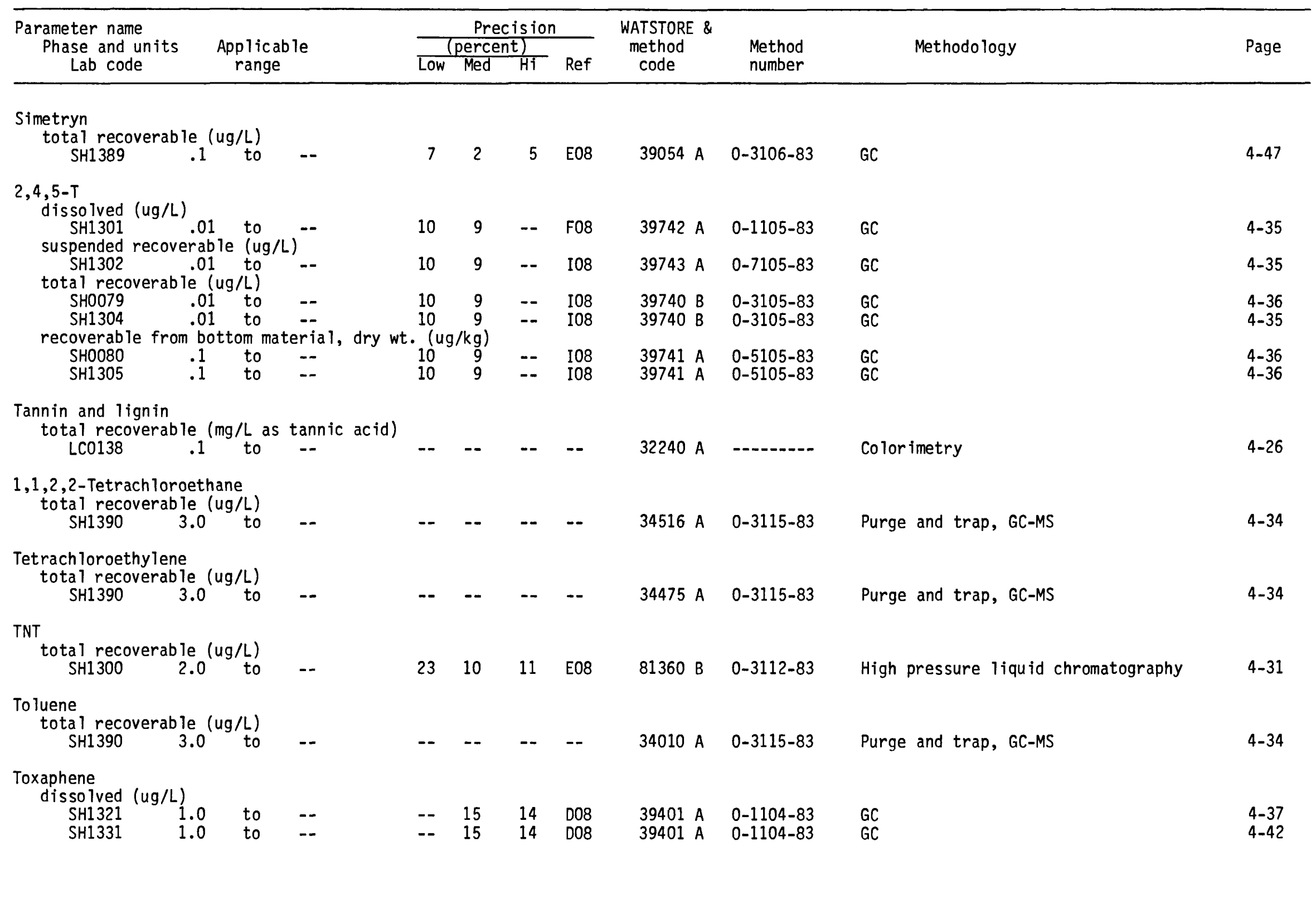


Table 5.3.1.--Index of analytical methodology for organic analyses--Continued

品

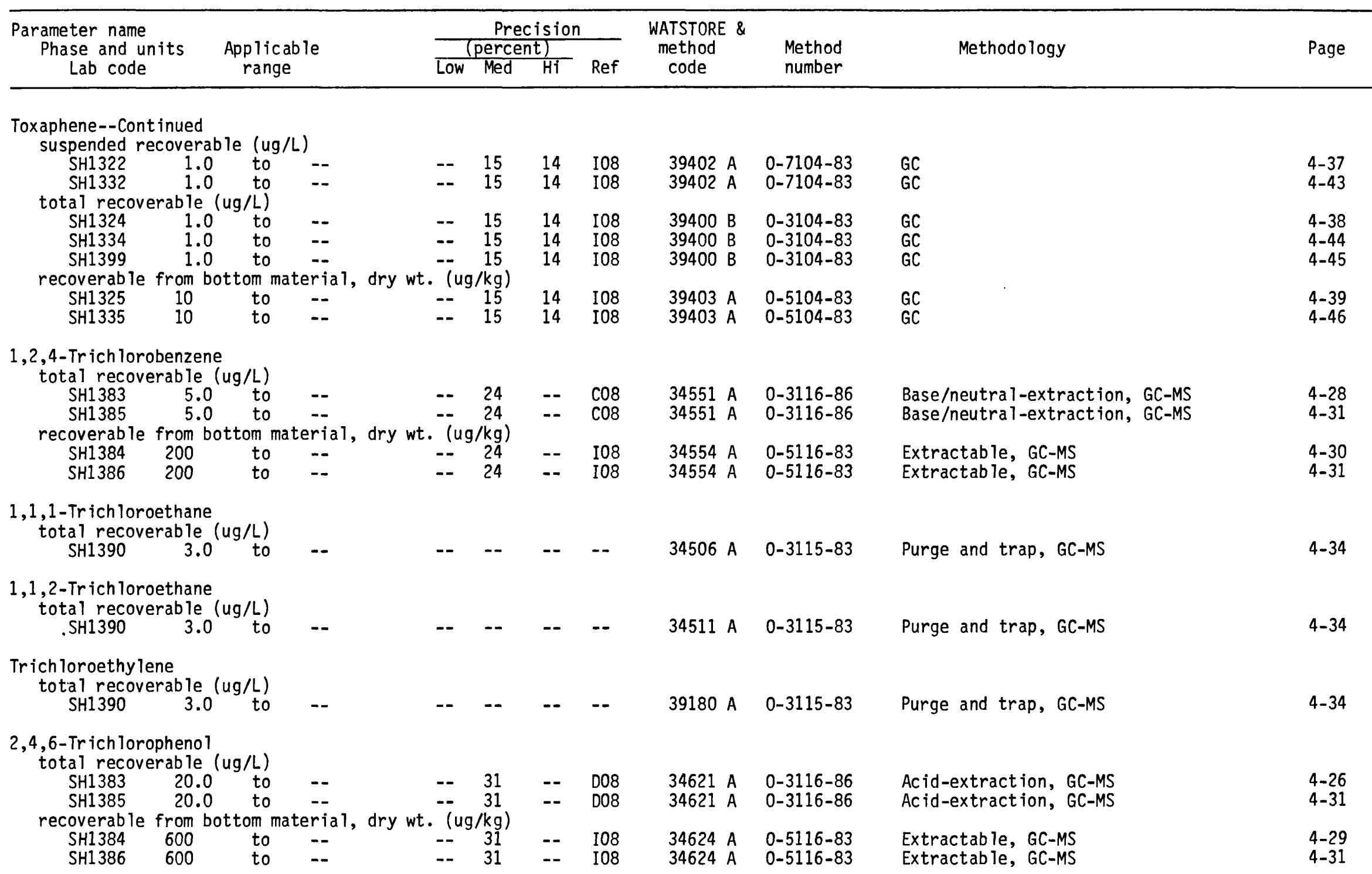




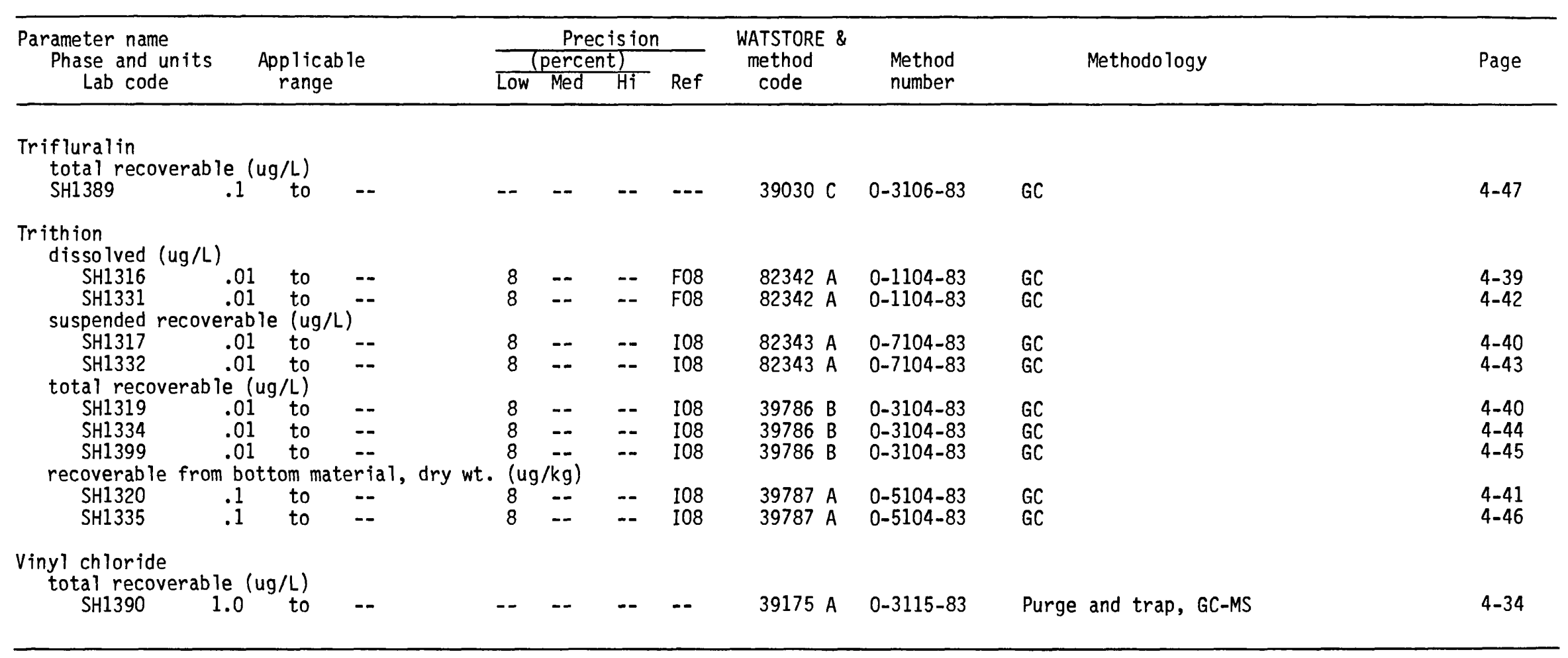


